\title{
The Performative Katherine Mansfield
}

A thesis submitted to the Victoria University of Wellington in fulfilment of the requirements for the degree of Master of Arts in English

Victoria University of Wellington

2017

Nicola Saker 


\section{Abstract}

This thesis looks at the role of performance in Katherine Mansfield's life and its influence on her writing technique. It argues that there is a consistent thread of active engagement with performance throughout Mansfield's life which profoundly influenced the content, construction and technique of her writing.

It is divided into three chapters. The first examines Mansfield's early years and the cultural context of colonial, Victorian Wellington and its performance culture as well as the familial and educational influences that surrounded her.

The second chapter explores her later cultural context in London in the first decade after the turn of the century. The importance of popular culture such as music hall is examined, and Mansfield's professional and personal performance experience is defined.

The third chapter involves a close reading and analysis of Mansfield's dramatic techniques through the examination of the stories as well as her use of theatrical imagery, motifs, allusions and plot details. 


\section{Acknowledgements}

I would like to thank the following people for their contribution to this thesis: Jane Stafford for her wise and sensitive supervision; Harry Ricketts for his initial guidance; Rebekah Galbraith for her constant support, both technical and academic; and Angelina Sbroma for her humour, energy and insight. I would also like to thank Mark O'Regan for his unfailing encouragement and,

lastly my parents, Dorian and Gay Saker, who read Mansfield themselves and to me. 


\section{Contents}

Abstract i

Acknowledgements ii

Table of Contents, Abbreviations 1

Introduction 2

Chapter One: Early Cultural Context 12

Chapter Two: Later Cultural Context 41

Chapter Three: Mansfield's Use of Stagecraft 66

Conclusion 106

Bibliography 108

\section{Abbreviations}

ATL Alexander Turnbull Library

JMM John Middleton Murry

KM Katherine Mansfield 


\section{THE PERFORMATIVE KATHERINE MANSFIELD}

The central argument of this thesis is that Katherine Mansfield's actual experiences as a performer had a profound influence on the content and construction of her stories. This argument is developed in three chapters, the first examining the writer's early cultural context, the next her later cultural context and the last, the crux of the matter, illustrating the use of dramatic techniques in her writing. The problematic nature of combining literary analysis and biography needs to be acknowledged at the outset. Graduate students are warned against "biographical criticism," as Suzanne Raitt has pointed out in her review of Sydney Janet Kaplan's work, Circulating Genius: John Middleton Murry, Katherine Mansfield and D.H. Lawrence. She wrote:

[Sydney Janet Kaplan] defends herself against the claim that this kind of criticism has a certain kind of naivety: 'A biographically informed criticism...cannot avoid making use of "experience," despite its contested and overly mediated representations'...But it is precisely in its sophisticated and understated exploration of the contestation and mediation of 'experience' that this book makes its greatest contribution. Experience become reflection, reflection becomes art or criticism, and that art or criticism becomes its own kind of experience $^{1}$

Clearly, this thesis accepts the permeability of Mansfield's life and writing in a similar fashion. Indeed, most analyses of Mansfield use a combination of her letters, journals and diaries along with other biographical material to illustrate their ideas and arguments. Where this thesis can be seen to differ is that its argument is not thematic, but technical. It posits that Mansfield's actual experience and engagement with performance resulted in her using stylistic techniques that are derived from a performance-based orientation. This argument necessitates a deconstruction of Mansfield's literary technique to support it but that, in turn, needs to be buttressed by evidence of the experience which informs the technique.

It can be argued that all biography is constructed, a fiction. This is particularly pertinent to Mansfield who not only demonstrably used excerpts from her

Professor Suzanne Raitt, Katherine Mansfield Studies, 3 (2011): 118-120. 
biographical writing (letters, journals, notebooks, diaries) in some of her stories but for many years also regarded her life as a dramatic work-inprogress. This concept will be threaded through the thesis but is secondary to the overall argument. The areas which need to be addressed with regard to this thesis are: the relevant critical field; modernism and multiple selves; Mansfield's performative personae; and, finally, performance theory.

The critical canon relevant to this thesis can be broadly divided into three categories: critical biographies, memoirs and academic scholarship. The biographies and memoirs combined (Alpers, Baker, Berkman, Boddy, Crone, Jones, Mantz, Meyers and Tomalin) all mention some or many of Mansfield's known performances and are essential in establishing the bedrock of Mansfield's experiences as a performer and also to give insight (subjective or otherwise) into her performative personality. In most of these works, her experience as a performer is noted in the same way as other biographical details, rather than as an appreciation of a significant element in her life and work.

It is surprising, therefore, that given the relatively consistent references to public performance in the biographical canon, academic scholars have not pursued this with more vigour. That is not to say that, again, there is no reference to it by critics, sometimes in detail. By way of example, Angela Smith has written of Mansfield as "Actress and Mimic: August 1908 November 1911"2 which concentrates on Mansfield's disguises and impersonations, and their implications for her work rather than the technical impact of her real, onstage experience. This is part of a larger syndrome: that there is comparatively little analysis in the critical canon of actually how Mansfield created the particular quality of her work, with its impression of "Page after page [giving] off the feeling of being still warm from the touch, fresh from the pen."3 Mansfield's first reader and earliest critic, John Middleton Murry, in his introduction to her journal, wrote:

Angela Smith, A Literary Life (Hampshire and New York: Palgrave, 2000), 46-68.

Elizabeth Bowen, "A Living Writer," ed. Jan Pilditch, The Critical Response to Katherine Mansfield (Connecticut, London: Greenwood Press, 1996), 71. Hereafter cited as ed. Pilditch, Critical Response. 
Her secret died with her. And of the many critics who have tried to define the quality in her work which makes it so inimitable, everyone has been compelled to give up the attempt in despair. ${ }^{4}$

Critics following Murry, whilst possibly not despairing, describe Mansfield's writing as elusive, ineffable, such as C.K. Stead's description: "[There is] an indefinable all-pervasive freshness in her writing, as if every sentence had been struck off first thing on a brilliant morning." 5 What this thesis aims to achieve is a precise and explanatory analysis of her literary technique. Other critics do allude to her writing's performative qualities, most notably Sarah Sandley ${ }^{6}$ in relation to film and, more recently, Maurizio Ascari, ${ }^{7}$ who expands on Sandley's work regarding Mansfield's experience as a film extra and the influence of cinema on her work. Because this particular niche of Mansfield's performance experience has been explored by these two critics, this thesis does not dwell on it other than to refer to it as part of her combined experience. Another factor influencing this decision is that there are but a few references to Mansfield's working in film (although she clearly experienced much as a viewer) compared with an involvement and appreciation of drama in both a theatrical and personal, informal sense. The publication of her specifically dramatic work is a slim volume, Katherine Mansfield Dramatic Sketches. However, in its preface an assertion is made that underpins the central argument of this thesis and also highlights the neglect of this aspect of Mansfield's work:

The dramatic sketches have not previously been collected in a single volume, and to that extent have not been accessible to the ordinary reader...Mansfield was as innovative in her writing of drama as she was in writing short stories. Indeed,

John Middleton Murry, Introduction, The Journal of Katherine Mansfield (London: Constable, 1927), 12. Hereafter cited as Journal.

5 C.K. Stead (ed.) Katherine Mansfield, Letters and Journals (Harmondsworth: Penguin, 1977), 19

6 Sarah Sandley "Leaping into the eyes: Mansfield as a Cinematic Writer," in Celebrating Katherine Mansfield: A Centenary Volume of Essays, eds. G. Kimber and J. Wilson (Basingstoke and New York: Palgrave Macmillan 2011), 72-83.

7 Maurizio Ascari, Cinema and the Imagination in Katherine Mansfield's Writing (Basingstoke and New York: Palgrave Macmillan, 2014). 
these dramatic sketches were vital to the development of her later and most acclaimed work. ${ }^{8}$

In the Introduction, the editors affirm the significance of her dramatic experience, and, like other critics, place it as thematically, rather than technically, significant:

Her dramatic sketches represent an experimental phase in her own writing, marking the transition between role-playing expressed in mime and music hall sketch and her precise documentation of the subtle, changing relationship between inner emotion and outer mask, which is the dramatic focus of her later stories. ${ }^{9}$

Anne Friis' analysis approaches the territory of this thesis:

The writing of a play would, indeed, seem to be congenial to her mode of expression; if we examine the structure of her stories we see that many of them might, with a slight modification, be converted into plays; they dissolve themselves naturally into a number of scenes; their effect is pre-eminently spectacular. ${ }^{10}$

It is my contention that much of the quality of Mansfield's writing is due to her use of stagecraft and dramatic techniques combined with an ability to think herself into her characters in a form of "method writing" as distinct from "method acting." An early critic, Conrad Aiken ${ }^{11}$ outlines this interpretation, which will be explored in the conclusion.

The remarkably performative quality of much of her life is especially pertinent to this thesis. The idea of life being a performance, or series of performances has, of course, an ancient lineage. Plato and Aristotle thought about the inter-relationship of life, theatre and what was, and wasn't, real. Mansfield would have been completely familiar with Shakespeare's words:

Preface, Katherine Mansfield Dramatic Sketches, ed. David Drummond (Palmerston North: Nagare, 1988), vii.

$9 \quad$ Introduction, Katherine Mansfield Dramatic Sketches, David Dowling, Wilhemina and David Drummond, ed. David Drummond (Palmerston North: Nagare, 1988), 12.

10 Anne Friis, Katherine Mansfield: Life and Stories (Copenhagen: Einar Munksgaard, 1946), 131.

11 Conrad Aiken, “The Short Story as Colour,” ed. Pilditch, 'Critical Response, 9-12. 
All the world's a stage,

And all the men and women merely players, They have their exits and their entrances;

And one man in his time plays many parts ${ }^{12}$

Mansfield's 'many parts' is an aspect of her performativity that has been explored by critics, and relates to her place as a modernist writer, which Angela Smith has pointed out:

It could be argued that awareness of the divided self is a central concern of modernism and has no essential relationship with liminality or with women's experience: The Love Song of $J$ Alfred Prufrock; The Waste Land, A Portrait of the Artist as a Young Man, Women in Love, The Secret Sharer, and Heart of Darkness, for instance, are clearly preoccupied with the divided self if not the fragmented self, and Woolf and Mansfield knew Conrad's, Joyce's, Lawrence's and Eliot's work. $^{13}$

The publication of the works of Freud, Jung, Darwin and Nietzche contributed to modernist writers' understanding and depiction of human nature. Mansfield as a modernist has been (and is being) evaluated and analysed, by Sydney Janet Kaplan, Dominic Head, Angela Smith and others. Brigid Brophy commented:

[Mansfield's] obvious - indeed, dazzling - talent is for multiple impersonation [this] polymorphous poseuse was in the habit of running up spare personalities for herself. ${ }^{14}$

It is frequently observed that these "spare personalities" are illustrated by her use of different names and pseudonyms: Mansfield Kätherine Schönfeld, Julian Mark, Karl Mansfield, Käthe Beauchamp-Bowden, Yekatarina, Katerina, K.M. Beauchamp, K. Mansfield, K.M., K.T., Kath, Lili Heron, Sally, The Tiger, Tig, Katya, Katy Mansfield, Kissienka - the roll-call of stage names goes on.

The earliest symbol of theatre (and of the more contemporary divided self) is one which is a recurring theme in descriptions of Mansfield, such as

William Shakespeare, As You Like It, 2,7:139-42

Angela Smith, A Public of Two (Oxford: Clarendon, 1999), 19.

Brigid Brophy, Don't Never Forget: Collected Views and Review (London: 1967), 257. 
those of Lytton Strachey: "an odd satirical woman behind a regular mask of a face"15; Lady Ottoline Morrell: "Her curious smooth unruffled face, like a Japanese mask" "16; and Leonard Woolf: "She had a masklike face and... seemed to be perpetually on her guard against a world which she assumed to be hostile." ${ }^{\prime 17}$ And Mansfield herself used the image in her now famous advice to John Middleton Murry:

Don't lower your mask until you have another mask prepared beneath. As terrible as you like - but a mask. ${ }^{18}$ [Original emphasis.]

Mansfield, one woman, played many parts from an early age. In an early letter to her cousin, Sylvia Payne, she wrote:

Would you not like to try all sorts of lives - one is so very small - but that is the satisfaction of writing - one can impersonate so many people ${ }^{19}$ [Original emphasis.]

Impersonation is a term commonly used to describe "a representation in bodily form, personify; pretend to be (another person) for purpose of entertainment or fraud; act (character). ${ }^{20}$ Aligning writing with impersonation is an early indication of how, at an interior, writerly level, she viewed performance as a fundamental device in her writing. There are many examples of Mansfield employing impersonation in her own life. Her first husband, George Bowden, described this ability and its effect:

[Mansfield was] dressed more or less in Maori fashion, with some sort of kerchief over her shoulders and there was something almost eerie about it, as though it were a psychic transformation rather than a mere impersonation. ${ }^{21}$

15 Virginia Woolf and Lytton Strachey: Letters, eds. Leonard Woolf and James Strachey (Harcourt, Brace, 1956), 60-2.

16 Ottoline Morrell, cited in Anthony Alpers, Life of Katherine Mansfield, (Oxford: Oxford University Press, 1980), 339. Hereafter cited as Alpers, Life.

17 Leonard Woolf, Beginning Again: An Autobiography of the Years 1911-1918 (London: Hogarth, 1964), 203-4.

18 To JMM, late July 1917, Collected Letters of Katherine Mansfield, eds. V. O'Sullivan \& M. Scott (Oxford: Clarendon Press) 1, 318. Hereafter cited as Letters with volume.

19 To Sylvia Payne, 24 April 1906, Letters, 1, 19.

20 The Concise Oxford Dictionary, ed. J. B. Sykes, Oxford University Press, 1982.

21 George Bowden, "A Biographical Note on Katherine Mansfield," cited in Alpers, Life, 87. 
Her ability to mimic was well known amongst the people who knew her, from her Queen's College ${ }^{22}$ friend, Marion Ruddick:

Mimicry was her strong suit and her sense of drama was faultless - she could think herself into any part. ${ }^{23}$

Mansfield practised this process, as Dorothy Brett recounted:

Katherine would take jobs - strange jobs - just for the experience. She would have strange relationships with people for the same reason. Her great delight was a game she played in being someone else. While riding in a bus or eating in a Soho café, she would suddenly become someone else. She would act the part completely, until she even got herself mixed up as to who and what she was...the acting became so real to her that she didn't always know which was her real self. ${ }^{24}$

Mansfield's exploration of role-playing was not idle amusement. She understood the essence of performance as a means of self-exploration and wrote of Hamlet:

So do we all begin by acting and the nearer we are to what would be the more perfect our disguise. Finally there comes a moment when we are no longer acting; it may even catch us by surprise...the two have merged; that which we put has joined that which was; acting has become action. The soul has accepted this livery for its own after a time of trying on and approving. ${ }^{25}$ [Original emphasis.]

As Vincent O'Sullivan suggested, this idea derives from Symbolist belief:

Apart from matters of style, I suggest that the strongest indications of Mansfield's apprenticeship to Wilde were the

22 Mansfield and her sisters Vera and Charlotte attended Queen's College in London from early 1903 to June 1906.

23 Marion Ruddick, "Memories of Katherine Mansfield's Childhood," MS papers 1339, 5, ATL. Cited in Alpers, Life, 37.

24 Dorothy Brett, "Reminiscences of Katherine," Adam International Review 370-75 (19723): 84.

25 The Katherine Mansfield Notebooks Margaret Scott (ed.) (Canterbury and Wellington: Lincoln University Press and Daphne Brasell, 1997), 2, 265. Hereafter cited as Notebooks. 
supposition that one can give to life the shape one decides upon, and the demand that experience be intense. ${ }^{26}$

Hanson and Gurr also remark upon Wilde's effect on her notion of the artistic personality:

The Symbolist belief in the artist's ability to create himself, to become his mask, sustained her throughout her career. ${ }^{27}$

Max Reinhardt, whose dramatic work Sumurun inspired Mansfield and is looked at in Chapter Two, worked in the Symbolist vein and once said: "Always act the part - and you can become whatever you wish to become!",28 This thesis will attempt to demonstrate that is just what Mansfield the writer did in her stories.

It is incumbent in a thesis which has "performative" as one of its primary descriptors to look to performance theory as a possible framework for its argument. Performance Studies, or Performance Theory, evolved in New York in the 1980s and its epicentre was New York University's Department of Performance Studies under the chair of Barbara Kirshenblatt-Gimblett. In the department when she became chair was Richard Schechner, a theatre practitioner and activist in the off-off-Broadway movement. His work Performance Studies, An Introduction ${ }^{29}$ is considered a foundation text. In it, Kirshenblatt-Gimblett outlined (rather than defined) the field:

Performance studies starts from the premise that its objects of study are not to be divided and parcelled out, medium by medium, to various other disciplines - music, dance, dramatic literature, art history. The prevailing division of the arts by medium is arbitrary, as is the creation of fields and departments devoted to each.

To study performance, as an art form that lacks a distinctive medium (and hence uses any and all media) requires attending to all the modalities in play. This distinguishes performance

26 Vincent O’Sullivan, "The Magnetic Chain: Notes and Approaches to KM,” ed. Pilditch, Critical Response, 133.

27 Clare Hanson and Andrew Gurr, Katherine Mansfield (London and Basingstoke: Macmillan Press, 1981), 11.

28 www.azquotes.com/author/49209-Max_Reinhardt. Accessed March 22, 2017.

29 Richard Schechner, Performance Studies, An Introduction (London and New York: Routledge, 2002). Hereafter cited as Schechner, Performance. 
studies from those that focus on a single modality - dance, music, art, theatre, literature, cinema ${ }^{30}$

Richard Schechner wrote:

As a field, performance studies is sympathetic to the avantgarde, the marginal, the offbeat, the minoritarian, the subversive, the twisted, the queer, people of colour, and the formerly colonized. Projects within performance studies often act on or against strictly ordered or settled hierarchies of ideas, organizations, or people. Therefore, it is hard to imagine performance studies getting its act together, or even wanting to. Those working in the field resist creating a new, singular body of knowledge or methodology of the kind cosmologists dream of in their quest for the "theory of everything". 31

The above may illustrate why Performance Studies is challenged both as unstable and, three decades since its development, as an emerging discipline. Yet its fluidity and instability offer a useful insight for this thesis. It is illustrative of Mansfield's modernity that a discipline developed and considered avant-garde in the 1980s reflects her own, personal fluidity regarding the boundaries of art forms (also characteristic of Modernism), gender roles and life itself. Performativity is:

a term very difficult to pin down. The words 'performative' and 'performativity' have a wide range of meanings ...more often they are used to loosely indicate something that is 'like a performance' without actually being a performance in the most orthodox or formal sense. ${ }^{32}$

A more explicit definition of it is as a broad term used to describe "the capacity of speech and communication not simply to communicate but rather act or consummate an action, or to construct and perform an identity." ${ }^{, 33}$ The most famous example used to illustrate this concept is the words: "I now pronounce you husband and wife." The sense in which it is used in this thesis is the former: relating to or of the nature of dramatic or artistic performance.

Barbara Kirshenblatt-Gimblett, Introduction. Schechner, Performance, 3.

Schechner, Performance, 3.

Schechner, Performance, 110.

Judith Butler, cited in Schechner, Performance, 128. 
For the purposes of this thesis, I have decided not to embrace an allencompassing Performance Studies approach. There is an abundance of material which places Mansfield literally on stage as a performer and provides a platform from which to demonstrate its influence on her writing. Performance runs through her life and work like one of the needles charting a complex line graph. It has peaks and troughs but is a consistent thread. The impact of this consistent, life-long thread on her work is at the core of this thesis. 


\title{
CHAPTER ONE: EARLY CULTURAL CONTEXT
}

"She was a born actress and mimic"

\author{
Ida Baker ${ }^{1}$
}

The central premise for this thesis is that Katherine Mansfield's active engagement with performance throughout her life profoundly influenced the content, construction and technique of her writing. The intention of this chapter is to illustrate how her family life and the wider cultural context of Wellington, where the family lived, contributed to her experience and the development of her appreciation of performing and performance culture. The early cultural environment of New Zealand is examined first, followed by Mansfield's own family environment. Secondly, Wellington's performance culture is explored, as well as Mansfield's musical training. Thirdly, her place in the Beauchamp family is reviewed as well as her formal education. All the sections pursue the idea that performance was a significant feature of Mansfield's experience.

"Home entertainment" played an important part in the lives of colonial families. The piano was the focal point of home and, more widely, community entertainment. The need for music and entertainment was felt immediately on arrival in New Zealand by early settlers. In Dunedin by 1861, for example, musical life was already well established:

The settlers continued as much of the musical traditions of their old home in the new as they could, and music was an important part of religious and secular life. With the influx of money and population following the discovery of gold, the demand for musical activities and entertainments increased and a more diverse musical life resulted. ${ }^{2}$

Edward Gibbon Wakefield, in 1860, wrote: "a remarkable and suggestive feature of the houses is the great number of pianos and harmoniums. There is probably no country in the world where a musical instrument worth from ten to

1 LM, The Memories of LM (London: Michael Joseph, 1971), 233. Hereafter cited as LM, Memories. [Mansfield renamed Ida Baker, Lesley Moore, which was subsequently abbreviated to LM.] Clare Gleeson, Meet me at Beggs (Wellington: Ngaio, 2012), 24. 
forty pounds is so common an accessory in the home even among the poor classes." 3 Wakefield might have considered it still more remarkable that this trend continued to develop to the extent it did. Quite how central the piano was to the lives of the colonists is illustrated by import statistics. The first, itemised statistics were started in 1881 and in that year 1,177 pianos were brought into the country. By 1900, the number had more than tripled to 3,583.

The piano was the indispensable fixture in many thousands of New Zealand front parlours during Victorian and Edwardian times and even later in the 1920s. De rigueur in middle and upper class homes, the instrument became a symbol of upward mobility for the working classes ... In many homes, the ability to play pieces on the piano helped settlers maintain cultural links with the 'old country. 4

Music was clearly important, but not the only form of entertainment. Recital was another accessible means of delivering a cultural experience:

In grander houses the drawing room, in humbler dwellings the parlour, was the centre for family gatherings and entertaining friends, and children learned from an early age to contribute to the evenings by learning a poem by heart, perhaps The Charge of the Light Brigade for the boys, or for the girls verses by New Zealand's melancholy bard, Thomas Bracken. ${ }^{5}$

Amateur theatricals were a feature of domestic entertainment, along with charades, dressing-up, and tableaux of scenes from literature such as: "Enid and Geraint"; "Home they brought her warrior dead"; "King Cophetua and the Beggar Maid." The necessity of do-it-yourself entertainment in colonial lives was enlarged by the contemporary notion of the importance of being socially accomplished. One sang, one recited, one danced.

A performer's first audience is their family and, in Mansfield's case, her family was typical of the colonial culture described above. Music and amateur theatrical performance was an intergenerational aspect of Beauchamp family culture. Katherine Mansfield's grandfather, Arthur Beauchamp, was a popular tenor singer at concerts. His son, Harold, learned the piano as a child

Edward Gibbon Wakefield, New Zealand After 50 Years, 34. Cited in R. D. Arnold, The Country Child in Later Victoria New Zealand, eds. H. Debenham and W. Slinn (Australasian Victorian Studies Association Conference Papers, 1982).

4 John MacGibbon, Piano in the Parlour (Wellington: Ngaio Press, 2007), 7. June A. Wood, Victorian New Zealanders (Wellington: A. H. \& A. W. Reed, 1974), 17. 
and was accomplished enough to accompany a singing group known as the Bijou Minstrels when a young man in Wellington. His memoirs state:

They were a merry crowd. We gave several performances, principally of the nigger minstrel type, for charitable purposes ... My ability at the piano was never great, the only pieces that I can remember that I used to play would be considered quite obsolete today, for instance The Maiden's Prayer, Golden Waves, Les Hirondelles, The Poet Mourant, The Joyful Peasant and so on. In those days we had to make our own pleasures without the assistance of motorcars, cinemas, cabarets or cocktail parties, which are fashionable today. ${ }^{6}$

His talent as a performer was not confined to music and attracted the attention of the local paper in which we are able to catch an extraordinary glimpse of Harold Beauchamp in his youth, before he married Annie Dyer. A report on Wellington thespian activities in the Evening Post makes mention of a performance by a 'Patchwork Company' formed c.1879. Its chief members were Robert Holiday, Robert Grant, F. W. Haybittle, C. J. Hill, J. W. Hill, E. J. Hill, C. J. M. Edwards, John Prouse, J. M. Clarke and Harold (later Sir Harold) Beauchamp:

The programme usually consisted of a Christy Minstrel first part (of prime vocal quality with John Prouse, Charley Edwards, and Ted and Jack Hill contributing sentimental songs and concert numbers) and a musical comedy 'sketch' as an afterpiece. In the sketch the ladies' parts were sustained, and well sustained, by Messrs Beauchamp, Gant and Holiday amateur actresses not being readily available in those Victorian days. ${ }^{7}$

There is a direct line between Harold Beauchamp's youthful experiences as a "nigger minstrel" and some of his daughter's later performances which illustrate her family's, and her own, omnivorous attitude to performance as a mix of "high" and "low" culture, which is significant in terms of her later ability to appropriate ideas and techniques from new media such as cinema. Her father wanted to learn the cornet in his youth. In an early notebook Mansfield playfully analysed them as a type and observed:

6 Harold Beauchamp, Reminiscences and Recollections, ed. Guy Scholefield (New Plymouth: T. Avery, 1937), 57.

Evening Post, 30 June 1930, 17. 
Players of the cornet should never attempt anything approaching what is commonly termed "Light music." They should stick to "Funeral Marches," "Lamentations," and a few of the average "Coronation Odes."

In the same piece, she acknowledges the catchiness of "light music":

I have nothing but the "Swannee River" on the brain, for weeks. I wake up with the "Swannee River," eat it with every meal I take, and go to bed eventually with "all de world am sad and weary" as a lullaby. ${ }^{8}$

"Swannee River" (also known as "Old Folks at Home") was written in 1851 for a New York blackface troupe, the Christy Minstrels. It is one of the earliest examples of a "coon song." Years after writing about "Swannee River" Mansfield is remembered performing at the Lady Ottoline Morrell's country estate, Garsington Manor:

she [Katherine] fetched her guitar and sang quaint old folk songs, negro spirituals, ballads of all kinds. She sang in a low, whispering voice, all caution momentarily forgotten, her quick expressive face rippled with light and fun, her humour bubbling over. ${ }^{9}$

Along with the piano and cello, which are well documented as instruments mastered by Mansfield, playing the guitar was another musical achievement. Mansfield's wider family group were also accomplished musicians and performers. Her uncle, Valentine Waters, was a Post Office official who played the church organ. He had a fine voice and was in demand for local opera and oratorio performances. He is considered the model for Jonathan Trout of "Prelude" and "At the Bay." Nora Crone mentions Valentine Waters organising the "family's charades and concerts." ${ }^{10}$ Antony Alpers illustrates his playful and exuberant nature:

Notebooks, $1,8$.

John Manchester, "Prologue" to Dorothy Brett's Lawrence and Brett: A Friendship (1974), 7. Cited in Jeffrey Meyers, Katherine Mansfield: A Biography (London: Hamish Hamilton, 1978), 203. Hereafter cited as A Biography.

10 Nora Crone, A Portrait of Katherine Mansfield (Ilfracombe: Arthur H. Stockwell, 1985), 15. Hereafter cited as Crone, Portrait. 
Uncle Val was certainly no Beauchamp, but there was something in him of the $\mathrm{Pa} \operatorname{man}^{11}$, which earned him the lifelong affection of his niece. For his garden, at the weekends, he used to clear the main road of its horse manure, and to the children he was everything an uncle ought to be. If shot with a popgun he could be relied upon to fall to the ground, moaning, "You've killed me, you brute.",

Uncle Val's two sons, Barry and Eric (Pip and Rags in "Prelude") contribute to the performative family culture. Eric, who became a music teacher, was an accomplished pianist and composer who wrote the scores for Tutankhamen (1923) and The Abbess of Whitby (1925), two acclaimed Auckland Amateur Operatic Society productions. Mansfield's sketch "By Moonlight” (1921) uses musicality within a family to demonstrate character differences. A daughter is playing the piano: “And the worst of it was Meg was practising. She'd just begun learning the piano, you remember. She was playing Rousseau's Dream". The banal superficiality of the mother is contrasted with the intense emotion of her daughter in the following dialogue:

There came a long soft chain of sound from the music room as though Meg had flung a bright loop \& snared the dreaming piano. We're going to try over Francie's new song, she said. This Life is Weary.

This Life is Weary, cried Mother. Oh dear - is it another tragic one? I can't understand why all these modern songs are so depressing. It seems so unnecessary...

Oh but it's fascinating, said Meg. And softly she played over This Life is Weary. You can't say you like Cupid at the Ferry better than that.?

I do, said Mother. I like songs about primroses \& cheerful normal birds and - spring and so on. ${ }^{13}$

The Beauchamp-Waters families were demonstrably performance-oriented and they would have been each others' audience. But family-as-audience has its limitations, as Claire Tomalin has pointed out:

Mansfield's term for loud, confident men like her father.

Alpers, Life, 11.

Notebooks, 2, 221. 
Katherine was always a performer. She needed to enchant an audience, but there was no-one in her family on whom she could successfully cast a spell. They simply did not wish to see her as she wished to be seen. ${ }^{14}$

Mansfield herself uses this in "Miss Brill," (1920) to illustrate the difference between performing for family and for others:

For although the band played all year round on Sundays, out of season it was never the same. It was like someone playing with only the family to listen, it didn't care how it played. ${ }^{15}$

The presence of playful, musical adults in a child's life is encouraging, enriching and imaginatively stimulating. It has been common to characterise Harold Beauchamp in an unsympathetic light as a business bore, who religiously jotted down the tonnage of the ships leaving Wellington in a notebook. Mansfield's account of his 1919 visit to her at Ospadaletti in Italy, in contrast, conveys a theatrically flamboyant character:

I didn't dare speak hardly because it was so wonderful, and people laughing and silly Pa talking Maori down the whistle to the chauffeur. Very silly - but very nice somehow...Pa and I talked and the sun streamed into the car...He made the running, talking French, telling stories, producing spectacles. (He had four pairs of them. Connie had three, and Jinnie had three.) At one moment they were all trying each other's on - in this little room. It was like a dream. ${ }^{16}$

Harold Beauchamp's theatricality (and that of his father, Arthur Beauchamp) is conveyed by the verbal playfulness with which Mansfield characterises Stanley Burnell, the "Pa man" in her Wellington stories, who is based on her father. In "Prelude" as Stanley Burnell carves the duck, he says:

"My father would say," said Burnell, "this must have been one of those birds whose mother played to it in infancy upon the German lute. And the sweet strains of the dulcet instrument acted with such effect upon the infant mind"17

14 Claire Tomalin, Katherine Mansfield: A Secret Life (London: Viking 1987), 14.

15 Katherine Mansfield, The Collected Stories (London: Penguin, 2007), 331. Hereafter cited as $K M C S$.

16 To JMM, 12 November 1919, Letters, 3, 90.

17 KMCS, 50. 
Also in "Prelude" is Stanley Burnell's daydream of a performance in church:

In fancy he heard himself intoning extremely well: "When thou did overcome the Sharpness of Death Thou didst open the Kingdom of heaven to all Believers."18

The italics are Mansfield's, writing the way in which Burnell would intone. It is Burnell's producer's note to himself, and Mansfield's to the reader. Throughout her life, Mansfield at times scorned her parents as materialistic philistines, calling them "thoroughly commonplace and commercial"19 but Harold Beauchamp's business ventures combined culture with commerce: Bannatyne \& Company, the importing firm of which he was head, was an agent for Dresden Piano Co. of Dunedin. As well as being Chair of the Board of the Bank of New Zealand, he also chaired the New Zealand Piano Co. "Culture" was clearly good business.

Her family's wealth, prominence and cultural receptivity afforded her close contact with first-class performers, especially musicians, whom the Beauchamps entertained in their homes. They also employed professional musicians as entertainment. The story "Sun and Moon" (1920) recalls musicmaking in a family home. In it, the preparations for a concert and party in a grand residence are viewed through the eyes of two young children, a boy and a girl. A piano tuner goes about his business:

He had a bag of tools on the piano and he had stuck his hat on a statue against the wall. Sometimes he started to play and then he jumped up again and looked inside. Sun hoped he wasn't the concert. ${ }^{20}$

The children are allowed to come downstairs and be "seen" by the guests before the Nurse takes them off to bed. The guests are described:

The drawing-room was full of sweet-smelling, silky rustling ladies and men in black with funny tails on their coats - like

KMCS, 36.

Notebooks, 1, 49.

KMCS, 154. 
beetles. Father was among them, talking very loud, and rattling something in his pocket. $^{21}$

Most of the adult Mansfield's known male partners (Garnet Trowell, George Bowden, Floryan Sobienowski, Francis Carco) were singers and/or musicians. Her father can be viewed as the genetic template for them: theatrical, musical and a performer to his bones.

In the time of Mansfield's Wellington and earlier, there was a great deal of local music-making. The Wellington Choral Society had been giving concerts since about 1860, an orchestral society was formed in 1871, the Amateur Operatic Society followed in 1888, the Liedertafel in 1891, and the Musical Union in 1895. Yet Mansfield's sister, Charlotte (known as 'Chaddie') wrote to a cousin:

Well dear it is absolutely devoid of art and so naturally the people are most uninteresting. Take my advice dear \& never come to the Colonies to live in, remain in England, how I wish I was there too. I would give the world to be back. I can't tell you how miserable it is as we have absolutely no friends. All the girls we used to know have grown up \& got married and don't seem the least interested in us, so it is a rather sad state of affairs, n'est-ce pas? ? $^{22}$

We can probably assume that by 'art' Chaddie meant to include, in a broad flourish, the fine (visual) arts, theatre and opera. Joanna Woods stated in her preface to Facing the Music: Charles Baeyertz and the Triad that her book's origins were her research of Mansfield's early life in Wellington:

My focus was on her cultural environment and as I combed the newspapers and journals of the period for evidence of artistic activities, I soon realised that contrary to what Mansfield would have us believe, the cultural life of early twentiethcentury New Zealand was remarkably vigorous.

At a professional level, theatrical performances and concerts abounded, often featuring international stars who were ably supported by local actors and musicians. At an amateur level, orchestras and art societies flourished in all the main centres

$21 \quad K M C S, 157$.

22 Chaddie Beauchamp to Sylvia Payne, early January 1907. Cited by Alpers, Life, 42. 
and almost every settlement boasted a choir or a play-reading group. ${ }^{23}$

Similarly, Peter Harcourt gave an overview of the development of musical performance in New Zealand in his book, Fantasy \& Folly, showed that modest theatrical performances in New Zealand began almost as soon as the colony was established and cited the development of amateur performance as particularly significant:

Some actors and performances were professional but generally speaking the drama was sustained at first by amateur groups, especially while British army officers were stationed in garrison towns during the land wars of 1845-1872. Those who were not participants made an enthusiastic audience. Amateur theatricals continued to be a favourite pastime, although they were for many years treated with kindly condescension as a vastly inferior alternative to professional theatre. This was particularly so once a genuine touring circuit had been created and overseas companies built it up as a distant but possibly profitable branch of international show business. ${ }^{24}$

The gold rush of the 1860s and the commensurate influx of immigrants created a commercial opportunity in providing them with entertainment and in the 1870 s theatres were built or spaces were converted in the main centres and most of the provincial ones. Professional performance in Wellington was mainly restricted to visiting companies, including that "bizarre and beloved theatre form, pantomime." ${ }^{25}$ At the 1988 Katherine Mansfield centenary conference held at Victoria University of Wellington, Professor John Thomson and a PhD student presented a compilation, "Entertainment in Wellington":

[It was] a reading of snippets from newspaper reviews of plays, music and other entertainments provided to Wellingtonians in the 1890s (and, though I forget, probably into the early 1900 s)...it was well received. ${ }^{26}$

It was designed to illustrate the cornucopia of theatrical and musical entertainment available during Mansfield's years in Wellington. The

23 Joanna Woods, Preface, Facing The Music: Charles Baeyertz and the Triad (Dunedin: Otago University Press, 2008), 9.

24 Peter Harcourt, Fantasy \& Folly (Wellington: Steele Roberts, 2002), 14.

25 Ibid. 15.

26 John Thomson, email to author, 13 April 2016. 
conference presentation doesn't exist as a text, but Thomson's book ${ }^{27}$ lists the professional and amateur dramatic and musical productions staged in New Zealand from 1891 to 1900. In 1900, when Mansfield was 12 and might possibly have been taken to some of these events, five professional touring companies visited Wellington, each staging between three and 12 productions. On the lighter side, Pollard's Opera Company offered: The Geisha; The Belle of New York; The Gay Parisienne; The French Maid; Olivette; Paul Jones; In Town; La Fille Du Tambour Major and The Gondoliers. Walter Bentley and the Ancelon Dramatic Company produced: The Silver King; David Garrick; My Life For His; The Bells; Hamlet; The Merchant of Venice; Cramond Brig; A House of Mystery; Dr Bill; Othello and The Christian. Musical offerings were also frequent. Pupils at Miss Swainson's school, which Mansfield attended from June 1900 to December 1903, were supported and encouraged to take advantage of these diverse and rich offerings, particularly those involving the school's own staff:

Mr Parker [the school's music master] conducted most of the great oratorios given for the first time in Wellington, and he encouraged the girls to go and hear these; over the years the girls saw him conduct, amongst others, The Creation, Elijah, The Messiah, Israel in Egypt, Dvorak's cantata, The Spectre's Bride, Sullivan's choral work, The Golden Legend and Mendelssohn's symphonic cantata, Lobgesang...a surprising number of overseas artists came to Wellington and Miss Swainson [daughter of the school principal and a music teacher] escorted her girls to their recitals, and also to the concerts given by Mr Parker's Glee Club and the Liedertafel. ${ }^{28}$

Some of the overseas artists who visited Wellington were entertained by the Beauchamps, which gave Mansfield access to them. Such access provided her with experiences she determined to use in her writing. The Polish violinist Leopold Premyslav visited Wellington in June 1907. Mansfield's journal entry of the time recounts their interaction:

27 John Thomson, The New Zealand Stage 1891-1900 (Wellington: Victoria University Press, 1993).

28 Tosti Murray, Marsden: The History of a New Zealand School for Girls (Christchurch: Marsden Old Girls' Association, Caxton, 1967), 206. Hereafter cited as Murray, Marsden. 
This afternoon a man is coming to see me, to bring his 'cello, to hear me play, and now that the moment est arrivé I do not want to see him. He is bloated, lover of a thousand actresses, roamer of every city under the sun, wealthy, bachelor, and yesterday when I met him I behaved like a fool - simply for no reason...now he comes. Kathie you are a hideous lunatic. He has such a miserably unintellectual head. No - I'm glad about the whole affair. I shall pervert it, make it fascinating. ${ }^{29}$

The extravagance of her description " $\mathrm{He}$ is bloated, lover of a thousand actresses" displays a visceral distaste for a celebrity's lifestyle and, equally, her unthinking response to it. It is an early example of what was to become a Mansfield motif: that any experience was worth having in order to create "copy" for her writing. It was both a way of justifying her behaviour and, at the same time, laundering its seediness into something worthwhile. Also worth noting is that she felt enough of a musician to play for him.

It is evident that the musical culture that Wellingtonians were exposed to was predominantly European and classical. The first production of a New Zealand written and performed work came with Tapu, written by Alfred Hill, which premiered at the Wellington Opera House on 16 February 1903. It was well reviewed:

For the first time on any stage there was produced an opera which essentially belongs to New Zealand - it is entirely of New Zealand in its scenery and local colour, and it is the work of two New Zealanders...

Also written by Alfred Hill, The Moorish Maid, opened in Wellington on 25 November 1905 and the Evening Post boomed: "Messrs Hill and Birch have produced a genuine comic opera of a high standard of merit...the author has written lyrics, and the composer has set them to music which rises superior to comic opera standard; and yet again the popular liking for musical comedy is catered for." 31 Mansfield didn't see these early illustrations of an emerging national musical and cultural identity. She was at Queen's College in London. Music was for her, as for many New Zealanders, a direct link to her cultural

Notebooks, 2, 101.

New Zealand Times, 17 February 1903, 23.

Evening Post, 26 September 1905, 18. 
heritage back "Home" in England and Europe. The examples above illustrate that there was, in fact, an abundance of cultural entertainment to be enjoyed in the Wellington of Mansfield's time, both home-grown and from "Home."

Music, in varying degrees of significance, features in 48 of the 88 short stories Mansfield wrote, mainly with reference to the piano, in descriptions of lessons, performances, practising, accompanying singers and simply as a piece of furniture. Piano playing was one of the accomplishments that prosperous parents expected their daughters to acquire. As it had been for earlier colonial settlers, the piano was the instrument of choice for the Beauchamps. Harold and Annie Beauchamp's children all learned to play it and, later, Mansfield also learned the cello.

Several critics, most notably Delia da Sousa Correa, ${ }^{32}$ have focused on the role of music in Mansfield's writing style. Sydney Janet Kaplan correlates Mansfield's training as a musician to her understanding of what it takes to develop a style, quoting the writer: "Out of technique is born real style, I believe...There are no short cuts." ${ }^{, 33}$ Mansfield's first performance-based ambition was to be a musician and it was only after her parents extinguished that ambition that she turned her attention to writing as her main means of expression:

A great change has come into my life since I saw you last. Father is greatly opposed to my wish to be a professional 'cellist or to take up the "cello to any great extent - so my hope for a musical career is absolutely gone ... But I suppose it is no earthly use warring with the Inevitable - so in the future I shall give all my time to writing. ${ }^{34}$

Her known musical training ceased when she left Wellington in 1908, other than a brief flirtation with opera singing:

32 Delia da Sousa Correa, "Katherine Mansfield and Nineteenth Century Musicality", Chapter 6, Words and Notes in the Long Nineteenth Century (Suffolk: Boydell, 2013) and "Musical Performance in Katherine Mansfield's Stories," Katherine Mansfield Studies 3 (September 2011): 21-34.

33 Sydney Janet Kaplan, Katherine Mansfield and the Origins of Modernist Fiction (New York: Cornell University Press, 1991), citing a letter to Richard Middleton Murry, 3 February 1921, Letters, 4, 173.

34 To Sylvia Payne, 24 April 1906, Letters, 1, 18. 
Katherine also met the woman who lived in the flat above: Madame Alexandra, who trained opera singers. She had heard Katherine singing and, coming down like a ship in full sail, had tried to persuade her to train for the opera. Katherine started lessons but then found that it meant giving herself completely to Madame Alexandra and stopped the lessons. ${ }^{35}$

An intrinsic part of musical accomplishment is performing to an audience and receiving recognition for the accomplishment. The recognition confers status on the performer's family, as Mansfield illustrates in Juliet ${ }^{36}$ when the father says: "Now is the time. What have I got for my money? Come along - deck yourself out, show the world you are expensive." In "An Ideal Family" (1921) Mansfield described such an attitude:

Hobbies couldn't pay for their horses...the sixty-guinea gramophone in the music-room for them to dance to...No, they were smart, good-looking girls...it was natural for them to be in the swim. As a matter of fact, no other house in the town was as popular as theirs; no other family entertained so much [old Mr Neave] had listened to praises of his wife, his girls, of himself, even. "You're an ideal family, sir, an ideal family. It's like something one reads about or sees on stage." 37

Harold Beauchamp was rewarded for his investment by the society pages of Wellington's newspapers and various periodicals such as the New Zealand Graphic and Ladies Home Journal, Weekly Press, Auckland Weekly News and Free Lance glowingly writing up these performances. "Ophelia," the ladies' correspondent for New Zealand Graphic and Home Journal, wrote:

Friday was the afternoon of Mrs Beauchamp's At Home, which proved particularly enjoyable. The hostess was assisted in entertaining by her clever daughters, who gave a really capital musical programme, including songs, together with solo and concert items on the violin, the cello and the piano. ${ }^{38}$

And "Iolanthe" reported in the Weekly Press:

LM, Memories, 60.

Notebooks, 1, 65.

KMCS, 370.

New Zealand Graphic and Home Journal, 11 May 1907. 
On Tuesday afternoon the Misses Beauchamp gave a girls' tea.

After tea, which was served in the dining room, songs were sung by Misses Beauchamp, Fulton, McTavish and Seddon. ${ }^{39}$

At a nurses' dinner in 1908 the hundred guests were entertained "with a brilliant duet for piano and cello by the Misses Beauchamp."40 The "success" of this musical education can be gauged by the confidence and competence necessary for Vera Beauchamp to compose two pieces of music with lyrics by her sister Kathleen: "Night" and "Love's Entreaty." These represent Mansfield's first published work. A verse from the latter gives the flavour:

If thou wouldst take my heart, my life

If I thy slave might be

I'd reek not for the world's hard strife;

Oh my love, I would live for thee - for thee. ${ }^{41}$

These compositions came about following a visit to Bollendorf in Germany in the summer of 1904, where they met up with the musical Trowell brothers. The pieces were published in Berlin, sponsored by the New Zealand Piano Company, of which, as mentioned earlier, their father was Chair. Their uncle, Valentine Waters, sang them at a Wellington Harbour Board dinner, to his brother-in-law, Harold Beauchamp, who was by then Chair of the Harbour Board. The songs are dedicated "To Our Darling Parents."

For Mansfield, music was not merely an accomplishment to be paraded on social occasions to enhance her family's reputation and her own chances of securing a suitable husband. It was a deeply felt affinity and a theme in her earliest writing, illustrated by the last verse of her poem "Music.",42

All the world is music

Wist ye not the music of the sea

The music of the birds, the winds, the flowers

'Tis all in all to me. ${ }^{43}$

Weekly Press (Christchurch), 8 July 1908, cited in Alpers, Life, 42.

Crone, Portrait, 49.

Alpers, Life, 35.

Notebooks, 1, 18

Notebooks, 1, 37 
The last line, in particular, while displaying the same pantheistic passion about music, is maidenly in comparison with one of her journal entries:

Talk of Art!! Ah! I am in Heaven. I have been with Fritz Rupp the Opera Singer. He has played, sang, acted, spoken. My sadness is gone, is a thing of the past. While such men live I am happy. O man you give me life. I felt my body vibrate to his singing. He is a true Musician. His eyes, his face, his look, he plays everything - Rigoletto, Wagner, Walkure, SaintSaens. Life, life is playing past me in a torrent of divine melody. Keep me at it. Keep me at it. Let me too become a great Musician. They are my people, by a glance we understand each other. There is fresh impetus. I adore them. ${ }^{44}$

Mansfield had piano lessons with Robert Parker at Miss Swainson's school when she was 12 . Two years later she met Tom Trowell, a young cellist, and persuaded her father to let her have cello lessons from his father. The timing of her musical training, and in particular her learning the cello, coincided with the hormonal surge now known as adolescence. Mansfield herself explicitly correlated music and sexuality:

All Musicians, no matter how insignificant, come to life emasculated of their power to take life seriously. It is not one man or woman but the complete octave of sex they desire. ${ }^{45}$

In her first piece of sustained fiction, the abandoned manuscript Juliet (1906) Mansfield describes the effect of the male character "David's" cello playing on Juliet in terms that convey an intensely sexual experience:

Juliet watched him with great pleasure and curiosity. A bright spot came into her cheeks, her eyes opened - but when he drew his bow across the strings her whole soul woke and lived for the first time in her life. She became utterly absorbed in the music. The room faded, the people faded. She saw only his sensitive inspired face, felt only the rapture that held her fast, that clung to her and hid her in its folds, as impenetrable and pure as mists from the sea ${ }^{46}$

Earlier in the story, Juliet had complained: "I have never heard a cello." In the above passage Mansfield describes a possession by music in language that

Notebooks, 1, 101.

Journal, 5.

Notebooks, 1, 52 
conveys a deflowering: Juliet is full of "great pleasure and curiosity." Her colouring changes and her eyes are "opened." When "David" "drew his bow across the strings her whole soul woke and lived for the first time in her life." After hearing her first cello, she experiences "rapture."

That Mansfield learned the cello bears closer inspection. When she started instruction, it had long been considered a masculine instrument, in part because the movements required to play it were thought antithetical to Victorian notions of grace associated with women:

The obvious impediment to [the cello's] acceptance for women was physical: anything held between the legs - whether horse, bicycle or cello - engendered discussion as to its suitability for women. $^{47}$

Being person-sized and positioned between the legs, its sexual connotations were obvious. The anatomical terms used to describe its parts add to the comparison: "belly", "neck" and so on. It was described in explicitly sexual terms by Marie Corelli, the best-selling novelist known to Mansfield, in a brief article she wrote:

Still when I look at Hollman and his big friend, and note how they love each other, how eloquently they converse together, how they whisper and laugh and murmur, how they fondle and caress each other...from the strings of the heavy, cumbrous thing, which, in the hands of a master, becomes a living, talking being - a being that laughs and weeps, and is capable of quick pulsations of joy and strong shudders of passion near akin to pain. ${ }^{48}$

Male critics writing later about female cellists were just as explicit:

At times...she [Suggia] seems crucified to the instrument, with arched eyebrows raised there is almost an expression of torture on her face, one seems to detect a writhing movement, that only self-mastery of art controls and one scarcely knows whether it is across the belly of the instrument between her

47 Beth Abelson Macleod, Women Performing Music: The Emergence of American Women as Instrumentalists and Conductors (Chicago: University of Illinois Press, 2004), 239.

48 Marie Corelli, "His Big Friend," The Theatre, 1 August 1884. 
thighs or across her own entrails that the bow is drawn to evoke the slow, deep music of these singing tones. ${ }^{49}$

There were examples of female cellists in a Venetian orchestra in the $18^{\text {th }}$ century, but they would have played it 'side-saddle.'As late as 1898, there were other ways in which women were instructed to play the instrument:

which are more graceful, and therefore more frequently followed. The first and best is to turn both legs to the left, bending the right knee and placing it under the left one. The left edge of the back should rest against the left knee, and the instrument against the chest, in a slanting position. The second is, to rest the right knee on a cushion or stool concealed by the back of the instrument, the latter leaning against the left knee. ${ }^{50}$

The invention of the endpin in the mid-half of the $19^{\text {th }}$ century helped male and female cello players, but it remained an 'unladylike' instrument, requiring the player to straddle it, legs apart. Orchestras were reluctant to have female cellists in the early $20^{\text {th }}$ century even when they were agreeable to women playing other instruments. The BBC Symphony Orchestra found female cellists problematic as late as the 1930s.

Mansfield's clothes of the time would have prevented any glimpses of ankle or calf, let alone thigh, but the fundamental playing position remains one that is suggestive of sexual engagement. That Mansfield began learning the cello as an adolescent from Tom Trowell, whose musical sons were the first (male) objects of her desire gives it a parallel role in the development of her sexual awareness and her early defiance of social and sexual norms and she characterised the instrument as her lover:

And that is my 'cello, my all in all

Ah, my beloved, quiet you stand

If I let the bow ever so softly fall

The magic lies under my hand. ${ }^{51}$

This poem demonstrates not only her profound attachment to the instrument but also possibly alludes to a common interpretation of women playing the

49 Havelock Ellis, Impressions and Comments, (2 ${ }^{\text {nd }}$ series) (London: Constable, 1921), 169 [describing a concert given by the Portuguese cellist, Suggia].

50 E. S. J. van der Straeten, The Technics of Violincello Playing (London: 1898), 107.

$51 \quad$ Notebooks, 1, 29. 
cello as masturbatory ("The magic lies under my hand") as the bow is stroked directly over the player's lap area. Mansfield described the importance to her of Trowell's instruction:

Never have I loved Mr Trowell so much, or felt so in accord with him, and my cello expressing everything. This morning we played Weber's Trio - tragic, fiercely dramatic, full of rhythm and accent and close shade...to hear that "Bravely done - you've a real good grip of it all - very good." I would not have exchanged those words for all the laurel wreaths in existence. ${ }^{52}$

She studied and played cello during her three years at Queens College, and her friend Ida Baker recalls:

Another friend was a rather wild young New Zealander, Ruth Herrick. She was younger than Katherine but shared her comings and goings in number 41. They went to concerts together in large, floppy black ties and wide, soft felt hats and assumed a rather slouching walk, imagining themselves to be young bohemian musicians. ${ }^{53}$

Mansfield was attracted to the idea of being a musician, so she dressed the part, walked the part, and talked the part. If accurate, this would be the earliest example of Mansfield exploring gender through a cross-dressing "performance." Whether or not this was the case, it is an early illustration of her willingness to become the part and the typically theatrical means she used to achieve it. Mansfield's use of costume and costume changes is explored in the next chapter. Mansfield also read herself into the lives of musicians:

And deeply I pored over the books of Youthful Musicians. Splendid - and tragic - and prophetic their faces gleamed at me - always with that strange haunted look. They had taken Life to them, and sung a Scarlet Song that had no ending and no beginning. And I read of all their resolves - and of their feverish haste, and the Phantastic Desires that sang themselves to birth ${ }^{54}$

This is not to undermine the seriousness of her study of music. Melissa Reimer illustrated how lists were an important part of Mansfield's modus operandi and

Notebooks, 1, 109.

LM, Memories, 26.

Notebooks, 1, 196. 
"provide further insight into the fiction she subsequently produced, and an unexpected way of accessing the contrary and elusive character of the woman herself." 55 One early diary ${ }^{56}$ has a list of "Books I have read" which includes How Music Developed by Henderson and another list "Music I have studied", which includes: Caprice (Noel Johnson); Warum (David Popper); Le Désir (part only) by Servais and Variations Symphoniques (part 2) by Boëllman.

A study of these composers illustrates that seriousness, but also the way in which Mansfield "mixed it up" when it came to her consumption of musical culture. Of the four composers, three are "serious" music and one "light" or popular. Noel Johnson (1863-1916) wrote songs that were popular and sung long after they first appeared, such as "Weep No More Ye Sad Fountains" and several others with German words. David Popper (1843-1913) was one of the $19^{\text {th }}$ century's great cellists and composed for the instrument; Adrien-François Servais (1807-1866) was another influential cellist and composer and Leon Boëllman (1862-1897) was a post-Romantic composer. The Variations Symphonique Mansfield alludes to was written for cello and orchestra. None of these names are well known now, but that is not to diminish their stature in Mansfield's time. Another list shows Mansfield analysing famous musicians' work:

In the music of Wagner there is that breadth \& universality by which emotion ceases to be personal and become elemental. He stood, as the music seemed to foam about him, as a rock against which the foam beats. The music of Wagner has human blood in it. What Wagner tried to do is unite mysticism and the senses...that insatiable crying out of a carnal voice... and the trilling of Chopin - the dew as well as the rain has a sound for him...Strauss Don Juan - passion \&...All the notes of the music evaporated like bubbles... Mozart Music sans le désir, content with beauty. ${ }^{57}$

This may be but one of Mansfield's many lists, but it shows her exercising her writerly 'chops' as she analyses major composers, using arresting imagery: "human blood in it"; "the music evaporated like bubbles."

55 Melissa C. Reimer, "Her Father's Daughter? Katherine Mansfield's Lists," Commonwealth Essays and Studies, 29, 2 (Spring 2007): 29.

56 Notebooks, 1, 31

$57 \quad$ Notebooks, 1, 214. 
Mansfield's immersion in music and musical culture shines through in her descriptions of music and musicians, such as in her early, unpublished story "Maata":

White smoke floated up from somewhere \& hung below the station roof like mist fires, dissolved, came again in swaying wreaths. Wonderfully beautiful, though Philip...He pointed it out to Maisie. "Look, girlie, look at that smoke. That is how the high note on a fiddle played pianissimo ought to sound." 58

Similarly, in "Bank Holiday" (1920) she describes a fiddler: "and a tall thin fellow with bursting over-ripe button boots, draws ribbons - long, twisted, streaming ribbons-of tune out of the fiddle." ${ }^{, 59}$ Music never ceased being part of her method. Seven months before she died, she wrote: "There is a really superb professional pianist here. He plays nearly all day \& one writes to his music." 00

Music is a pattern of sounds and Mansfield's expressed interest in performing work in which "Tone should be my secret - each word a variety of tone" ${ }^{~} 61$ is using the essence of musical composition to create a spoken work. This was then developed into a technique of writing in which she chose "not only the length of every sentence, but even the sound of every sentence..."I chose the rise and fall of every paragraph to fit...I read it aloud - a number of times - just as one would play over a musical composition",62 [Original emphasis.]

When mulling over The Oxford Book of English Verse in 1915, Mansfield complained about some poets, using her appreciation of music as a metaphor:

[hardly anyone] seems to understand "what the middle of the note is ... It's not that they are even 'sharp' or 'flat' - It's something much more subtle - they are not playing on the very note itself ${ }^{63}$ [Original emphasis.]

Notebooks, 1, 258.

KMCS, 364

[Draft] To Ida Baker, 3 May 1922, Letters, 5, 172.

To Garnet Trowell, 2 November 1908, Letters, 1, 84.

To Richard Murry, 17 January 1921, Letters, 4, 165.

To JMM, 9 December 1915, Letters, 1, 205. 
Mansfield was 'the middle note' in her family. She existed between two older sisters, Vera and Charlotte, and two younger siblings, Jeanne and Leslie. A sister, Gwen, immediately younger than her, had died in early infancy and she never forgot the sense of being excluded from her grandmother's arms by the dying infant:

Her name is Gwen, said the grandmother. Kiss her. I bent down and kissed the little goldy tuft. But she took no notice. She lay quite still with her eyes shut. Now go and kiss mother, said the grandmother. But mother did not want to kiss me. Very languid, leaning against some pillows, she was eating sago. ${ }^{64}$

She experienced her parents as emotionally absent. Her father was a busy man on the make and her mother seemed exhausted by childbirth and maternity. Fat, by her mother's description, bespectacled and with an intense sense of never receiving enough attention, the youthful Mansfield considered herself apart. $^{65}$ In "Juliet" (1906), an early attempt at fiction, albeit clearly autobiographical, she wrote: "Juliet was the odd man out of the family - the ugly duckling. She had lived in a world of her own, created her own people, read anything \& everything which came to hand, was possessed with a violent temper, and completely lacked placidity." ${ }^{, 66}$ A child who considers themselves the "odd one out" often becomes an observer, and powers of observation are fundamental to a writer:

According to the Waters' [her aunt and uncle's family] "ladyhelp", Rose Ridler, she (Mansfield) had a penetrating gaze which disconcerted grown-ups. She would stare at them with those keen brown eyes, take them in, and go to someone else with a too-revealing comment. [An almost identical observation was made much later by Bertrand Russell.] Her mother had no affection for her, or so it appeared to Rose. She preferred her other daughters. ${ }^{67}$

Mansfield struggled to be noticed and performing, to family, friends and herself, was one way to do it: Her youngest sister [Jeanne] recalled Kathleen 
coldly setting out to make an elderly friend weep with her recitation of "Evelyn Hope" $(1855)^{68}$ In one of her adolescent notebooks she wrote about a fictitious character who was, like her, a third child: "She had vague notions that it was always, would always be the third who was the favourite of the gods. The fairy tales that she devoured voraciously during her childhood helped to stimulate the thought". ${ }^{69}$ In "The Garden Party" (1921) Mansfield describes a daughter somewhat desperately seeking maternal approval for performance:

[Jose's] face changed. She clasped her hands. She looked mournfully and enigmatically at her mother and Laura as they came in. "This Life is Wee-ary...But at the word "Good-bye" and although the piano sounded more desperate than ever, her face broke into a brilliant, dreadfully unsympathetic smile. "Aren't I in good voice, mummy?" she beamed.

In "All Serene" (1917) Mansfield switches the viewpoint of the child seeking approval for performance to the smugness of a child who is acknowledged by her mother: "she detected that morning just the very faintest showing-off. Children who know they are admired look like that at their mother." ${ }^{, 71}$ Clearly, Mansfield's early family and local environment were hospitable and encouraging to those who participated in performance.

Next to family, schooling would provide the most significant step in Mansfield's experience and participation in performance. Mansfield attended three schools in Wellington. When the family lived at Chesney Wold, the children went to Karori Primary School; on their return to Thorndon in 1898 she started at Wellington Girls' High School (now Wellington Girls' College) and in 1900 she and her sisters moved to Mrs Swainson's ${ }^{72}$ private school at Fitzherbert Terrace. Karori Primary School and Wellington Girls' College were state schools.

68 Vincent O'Sullivan, Introduction, Letters, 1. "Evelyn Hope" the poem by Browning, has a theme of youth and death. Its first verse: Beautiful Evelyn Hope is dead!/Sit and watch by her side and hour/That is her book-shelf, this her bed/She plucked that piece of geranium flower/Beginning to die too, in the glass/Little has yet been changed, I think/The shutters are shut, no light might pass/save two long rays through the hinge's chink.

69 KM's MS notes in ATL. Cited in Claire Tomalin's A Secret Life (London, Penguin, 1988), 14.

70 KMCS, 251

$71 \quad K M C S, 477$. 
By the time Mansfield started school, the hotch-potch of missionary schools and private establishments in different provinces had been ironed out by the abolition of provinces in 1876. That ushered in the Education Act of 1877 which made schooling compulsory, free and secular. The following year, 1878, a national curriculum was devised:

A national syllabus was prescribed for the 'Standards.' In order to be promoted from one standard to the next, pupils were required to pass an examination, supervised by an inspector, in reading, spelling and dictation, writing, composition, arithmetic and, at Standard VI level, geography and drawing. ${ }^{73}$

Such a syllabus would not seem to encourage experience or appreciation of performance, other than what individual teachers may have been able to introduce into their classrooms.

The Beauchamp girls spent one term at Wellington Girls' High School before moving to Miss Swainson's school on Fitzherbert Terrace. Its original prospectus states "Mrs Swainson" ${ }^{74}$ receives Young ladies as Boarders and Day Pupils" and goes on to list the costs per term. Featured under "Extras" are:

Music Lessons; Singing Lessons (private lessons); Singing Lessons in class; Music lessons, every day or two lessons a week; Drawing Lessons; French Lessons and Dancing Lessons. $^{75}$

The "Extras" were in addition to a curriculum based on that of the early 19th century-denominational schools in England and in content it differed little from Marianne and Jane Williams' school at Paihia, the first European girls school in colonial New Zealand, which opened in May, 1927:

73 J. Simon, "Historical Perspectives in Schooling," The Politics of Learning in Aotearoa New Zealand, eds. E. Coxon, K. Jenkins and J. Marshall, L. Massey (Palmerston North: Dunmore Press, 1994), 63.

74 For clarification: Mansfield went to "Miss Swainson's" school. Miss Swainson's mother, Mrs Mary Ann Swainson started a school in 1870 after her husband died and she had five young children. The school outgrew its premises on the Terrace and she set up Mrs Swainson's school on Fitzherbert Terrace, off Hobson St, in 1878. This is where Mansfield went for three years from 1900. Her daughter, Miss Mary Swainson, taught music at the school and took over the running of it a few years before her mother's death in 1897.

75 Murray, Marsden, 48. 
There was the same emphasis on religious instruction, the 'classics', and the basic subjects: reading, writing, arithmetic, history and geography. But there was room and staff now for the more advanced teaching of French, music, and drawing. ${ }^{76}$

The staff member Mrs Swainson recruited to teach music was Mr Robert Parker, a remarkable asset from any perspective. He taught Mansfield and her sisters piano and singing. Robert Parker arrived in New Zealand in 1869 and was appointed organist and choirmaster at St Paul's in Wellington in 1878. His experience and background were impressive:

Born in London, he studied as a boy with the organists of All Saints, Margaret Street, Exeter College, and the Chapel Royal. He took violin and piano lessons, and choral work with the choirmaster of St Paul's Cathedral who was also professor of singing at the Royal Academy of Music. He intended to take Holy Orders, and won a scholarship to Queen's College, Cambridge, but ill health prevented him from studying... Robert Parker would certainly have been one of Britain's foremost organists and choirmasters if his health had not got progressively worse, which caused him to come to New Zealand to seek its restoration. ${ }^{77}$

His health was restored by the change of climate and he lived to be 90 . Sixty of those years were associated with Miss Swainson's school and, as it later became, Samuel Marsden Collegiate. He was what Mansfield would later call a first-chop musician and was her first "master." His influence on the school and its pupils is evident in one old girl's letter written when he died:

Those of us who were privileged to be his pupils and friends have cause to be grateful that our lives have come under his influence. Not only was our education musically developed, but he taught us to appreciate and look for the beauty both in literature and art. He did his best to help our minds grow in all directions and there cannot be one of us who does not cherish the refining and creative influence that still lingers ${ }^{78}$

His influence on Mansfield was not only musical. In her story "The Wind Blows" (1915) she conjures the atmosphere of a piano lesson in a drawing room with "Robert Bullen":

Murray, Marsden, 50.

Murray, Marsden, 205.

Te Kura [Samuel Marsden Collegiate school magazine], 1937, 53-54. 
It smells of art serge and stale smoke and chrysanthemums ... there is a big vase of them on the mantelpiece behind the pale photograph of Rubenstein ... à mon ami Robert Bullen ... Over the glittering black piano hangs "Solitude" - a dark, tragic woman draped in white, sitting on a rock, her knees crossed, her chin on her hands ... [The teacher opens an album and says] "Let's have a little of the old master" [and as she played] the crotchets and quavers [danced] up and down the stave like little black boys on a fence.

The "stale smoke," the chrysanthemums (a flower often used by Mansfield for its charming smell, which is a puzzle to contemporary readers) the use of French and the "glittering" black piano convey an atmosphere of adult sophistication and a cultivated sensibility. It describes a glimpse into a world that Mansfield wished to enter.

The ability to hold people's attention is fundamental to teaching and to performance. Much of this has to do with physical presence and voice. In two stories, Mansfield uses a school classroom as a stage setting and a teacher as the central character and performer. "The Singing Lesson" (1920) concerns a singing teacher, Miss Meadows, who has received a note from her fiancé breaking off their engagement. She takes her lesson and Mansfield makes the story "perform" the text, with the class singing a lament at the beginning of the lesson, which mirrors Miss Meadows' despair and then, later, when she receives notice that the engagement is back on, a more joyous song reflects her elevated mood:

We come here Today with Flowers o'erladen With baskets of fruit and ribbons to boot, To-oo Congratulate ${ }^{79}$

And Miss Meadows' response:

Stop! Stop! cried Miss Meadows. "This is awful. This is dreadful." And she beamed at her girls. "What's the matter with you all? Think, girls, of what you're singing. Use your imaginations. With Flowers o'erladen, with Baskets of Fruit and Ribbons to boot. And Congratulate." Miss Meadows broke off. "Don't look so doleful, girls. It ought to sound warm,

$79 \quad K M C S, 349$ 
joyful, eager. Congratulate. Once more. Quickly. All together. Now then!"

And this time Miss Meadows' voice sounded over all the other voices - full, deep, glowing with expression. ${ }^{80}$

The critic Delia da Sousa Correa comments on this ending:

And thus the story ends with a moment of ironic linguistic performativity, in its most exact sense, as the sung lyrics perform the act of congratulation upon Miss Meadows' continued engagement. ${ }^{81}$

Another story, "Carnation" (1918), focuses on two pupils in a French class, one of whom has a sexual experience while listening to her French teacher and observing a workman outside the classroom. It is set at Queen's College in London and is more fully analysed in Chapter Three.

Robert Parker was not the only experience of a "first-chop" practitioner for Mansfield at Miss Swainson's. Mrs Henry Smith, who famously wrote of her famous pupil, Kathleen Beauchamp, that she was "a surly sort of girl" whose compositions were "too prolific, poorly written, poorly spelled and careless," and that she "put herself in too much" " 82 as an outstanding teacher. A colleague of Smith, Fanny Irvine-Smith, referred to her as being "one of the ablest literary scholars and critics that the city [Wellington] possessed, and like her cousin, Charles Kingsley, ever an ardent humanitarian." 83 An old girl wrote:

She had the gift - new to me then - of holding her listeners, no matter what the subject (even French verbs!) and instead of waiting for the hour to strike we were always sorry when the lesson was over. Her literature and scripture lessons were models of what teaching should be. She first wakened me to the wonders of Shakespeare, and I remember with what keen appreciation we grappled with Coriolanus ${ }^{84}$

\footnotetext{
$80 \quad$ Ibid.

81 Delia da Sousa Correa, "Musical Performativity in the Fiction of Katherine Mansfield," Word and Music Studies, 12 (2011): 71-86.

82 Murray, Marsden, 66.

83 F.L. Irvine-Smith, The Streets of My City (Wellington: A.H \& A.W. Reed, 1949), 186.

84 Murray, Marsden, 59.
} 
Miss Swainson herself was a musician and taught piano to the junior classes and singing at the school. She may also have endeared herself to Mansfield for reasons other than her musicality:

[The boarders] said they could certainly smell cigarette smoke when Miss Swainson kissed them goodnight ... [they had] a half-shocked admiration that Miss Swainson dared to smoke in an age when smoking was considered 'fast." 85

The influence of teachers and school culture cannot be under-estimated. At Miss Swainson's, Mansfield was embedded in female culture (Robert Parker aside), with role-models such as Miss Swainson herself and her staff offering a wide range of intellectual stimulation that included a dedication to performance. As mentioned earlier, teaching itself involves performance and memorable teachers often employ dramatic techniques to hold the attention of their pupils:

When the headmistress reads Dickens aloud there is something fascinating in her voice that I could listen to for years and years. She is reading David Copperfield. ${ }^{86}$

The appearance of teachers also plays a part on impressionable minds. Miss Swainson was talented, energetic, young and musical and usually dressed in a

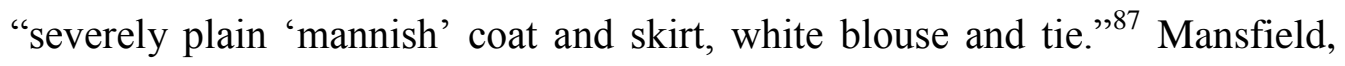
who became known for her fashion performances and everyday costume changes, said she "liked a line around her" ${ }^{\prime \prime 8}$ and one of her husband's early memories of her recalled her boyish appearance:

She was ready to go out, dressed in a tailored suit of dark blue serge, with a small cream-coloured straw hat trimmed with a tiny bunch of gay flowers - there was something almost boyish about her. ${ }^{89}$

Another teacher at the school, Miss Eva Butts, would apparently arrive at work on horseback wearing purple tweed and appears in the school's history as a

\footnotetext{
85 Murray, Marsden, 57.

$86 \quad$ Notebooks, 2, 26.

87 Murray, Marsden, 54.

88 Virginia Woolf, 16 January 1923, ed. Anne Olivier Bell, The Diary of Virginia Woolf (London: Hogarth, 1978), 2, 226.

89 JMM, Between Two Worlds, an Autobiography (London: Jonathan Cape, 1935), 194.
} 
keen hockey player. Miss Butts also receives special mention as giving "outstanding service in the games, dramatic and musical entertainments in the school." $" 90$ The earliest play known to have been produced at the school was $A s$ You Like It in 1890. Records are patchy but in 1897 scenes and choruses from The Geisha were put on; followed by Sappho (1898); Cinderella (1899) and in 1900, Miss May Taylor produced Alice in Wonderland. This was a break-out year for Mansfield's experience of performing to an audience larger than her family. She and her sister Charlotte were Tweedledum and Tweedledee in Alice in Wonderland, with a pupil named Gladys Rhind as Alice. This was followed by her being given the lead role by Miss Butts in a series of impersonations, Mrs Jarley's Waxworks. Mrs Jarley is a character in Charles Dickens' The Old Curiosity Shop who so captured the public's imagination that "Mrs Jarley" performances began as community and charity entertainments all over the English-speaking world. In her 1941 novel, Little House on the Prairie, Laura Ingalls Wilder described one:

After some moments of gazing on those waxen figures, Mrs. Jarley stepped from behind the drawn-back curtain. No one knew who she was. She wore a sweeping black gown and a scoop bonnet, and in her hand she held the teacher's long pointer. In a deep voice she said, "George Washington, I command thee! Live and move!" and with the pointer she touched one of the figures. The figure moved! In short, stiff jerks, one arm lifted and raised from the folds of white cloth a wax-like hand gripping a hatchet. The arm made chopping motions with the hatchet. Mrs. Jarley called each figure by name, touched it with the pointer, and each one moved jerkily. Daniel Boone raised and lowered a gun. Queen Elizabeth put on and took off a tall gilt crown. Sir Walter Raleigh's stiff hand moved a pipe to and from his motionless lips. One by one all those figures were set in motion. They kept on moving, in such a lifeless, waxen way that one could hardly believe that they were really alive. When finally the curtain was drawn to, there was one long, deep breath, and then wild applause. All the wax figures, naturally alive now, had to come out before the curtain while louder and louder grew the applause. ${ }^{91}$

\footnotetext{
90 Murray, Marsden, 183.

91 Laura Ingalls Wilder, Little Town on the Prairie (New York: Harper, 1941), 97.
} 
Presumably performances varied from place to place and country to country, with the wax figures changed to achieve relevance to the performance's specific location.

The works of Dickens feature in another account of a performance of sorts. In one of her journals Mansfield recalled: "Jinne Moore was awfully good at elocution. Was she better than I? I could make the girls cry when I read Dickens in the sewing class - and she couldn't"92 Mansfield's ambitions as a performer clearly did not include being an understudy. Mansfield's educational experience supported and encouraged performance and performative skills such as recital, musical training and dramatic productions.

This chapter demonstrates that Mansfield's familial, societal and educational background all supported and contributed to the development of her performative personality. Chapter Two examines how that translated into employment as a performer in a city which had been an epicentre for the performing arts for centuries.

Notebooks, 2, 24. 


\section{CHAPTER TWO: LATER CULTURAL CONTEXT}

"Were I perfectly sincere I'd have to confess that I was always acting a part in my old palmy days."

$$
\text { Katherine Mansfield }{ }^{1}
$$

The previous chapter has outlined Mansfield's youthful experiences of performance and performance culture. The purpose of this chapter is to illustrate the cultural context of the London she returned to in 1907 and how persistent a performer Mansfield was from the time she left New Zealand to her death. Four months after landing in London in 1908, Mansfield was articulating ambitious plans for performance:

I have a strange ambition - I've had it for years...It is to write - and recite what I write - in a very fine way - you know what I mean...Revolutionise and revive the art of elocution - take it to its proper plane... and express in the voice and face and atmosphere all that you can say. Tone should be my secret each word a variety of tone...I should like to do this - and this is in my power because I know I possess the power of holding people $^{2}$

It is interesting to explore Mansfield's lofty ambition to "revive the art of elocution." Elocution developed as a field in the early 18th century. It grew out of theories about voice qualities and attempts to classify them into 35 distinct categories under four different kinds of voice such as Whispering; Natural; Falsette and Orotund. ${ }^{3}$ According to Andrew McCann, it burgeoned in the late- $18^{\text {th }}$ and early $19^{\text {th }}$ centuries:

it was directly related to the codification of class differences in styles of speech, such that "talking proper" became a sign of

To Dorothy Brett, 10 June 1919, Letters, 2, 328.

Letters, $1,84$.

James Rush, The Philosophy of the Human Voice (1827), cited by Giles Wilkeson Gray, "The 'Voice Qualities' in the History of Elocution," The Quarterly Journal of Speech, 29, 4: 1943. 
distinction with much broader social and political implications than it had previously had. ${ }^{4}$

McCann's subject, the early elocutionist John Thelwall, wrote his own definition of it:

Elocution is the Art, or the Act, of so delivering our own thoughts and sentiments, or the thoughts and sentiments of others, as not only to convey to those around us (with precision, force and harmony) the full purport and meaning of the words and sentences in which those thoughts are cloathed (sic) but, also, to excite and impress upon their minds - the feelings, the imaginations and the passions, by which those thoughts are dictated; or with which they should naturally be accompanied. $^{5}$

It evolved into the performative art of public speaking and recitation as well as speech improvement. The surge of professional theatre and music hall entertainment from the mid- $19^{\text {th }}$ century meant it lessened in influence, which Mansfield refers to in the letter above. By referring to its pedigree, she shows an early awareness of the power of voice, which is a recurring motif in her stories and examined more fully in Chapter Three. There is evidence that her ambition to perform her work never left her. Less than a year before she died, she wrote:

I intend next Spring to go to London, take the Bechstein Hall and give readings of my stories - I've always wanted to do this ... it would be a great advertisement. Dickens used to do it. He knew his people just as I know old Ma Parker's voice and the ladies (sic) maid.

Mansfield's confidence in her ability as a performer is illustrated in the letter above. The Bechstein Hall opened in 1901 with a seating capacity of 550. It is now known as the Wigmore Hall. The influence of Dickens on Mansfield has been explored by Angela Smith in her paper, "Mansfield and Dickens: I am not

4 Andrew McCann, "Romantic Self-Fashioning: John Thelwall and the Science of Elocution," Studies in Romanticism, 40, 2 (Summer, 2001): 215-232. Hereafter cited as McCann, Self-Fashioning.

5 McCann, Self-Fashioning, 218.

To Ida Baker, 30 April 1922, Letters, 5, 160. 
reading Dickens idly" and others, concentrating primarily on theme and style. But Mansfield also inhabited a performance culture he was part of 50 years earlier, particularly with regard to music hall. In 1865, the song that was on everyone's lips was the exuberantly nonsensical "Slap bang, here we are again!" In Dickens' journal, All the Year Round, he wrote:

Everybody, old and young, male and female, grave and gay, lively and severe, sang it or hummed it... Well might the philosopher observe 'Let me write the songs of my country and I do not care who makes the laws.' What influence do our lawmakers exercise at the present moment compared to that which is wielded by the author of "Slap bang, here we go again"?

Dickens' first choice of career was acting and was only abandoned following the extraordinary popularity of Pickwick Papers. He retained a lifelong love of theatre, exercised through household entertainment and amateur theatricals. His reading tours, where he read from his work and which Mansfield is referring to, were enormously popular, with his enactment of the death of Bill Sykes a tour de force.

When Mansfield departed from Wellington in 1907, she had enough competence and confidence in her abilities to start earning money as an entertainer shortly after she settled in London. To call this the beginning of a career would be to overstate the case but, put together, the known episodes represent a constant and recurring involvement with performance of one kind or another. The allowance of NZ£100 a year that her father gave her in 1907 is the equivalent of NZ $\$ 16,098^{9}$ in today's money. It is understandable that Mansfield sought to augment it with earnings from other sources. Mansfield's known performances include both paid and unpaid. For the purposes of demonstrating the significance of performance in her experience, both are included in this chapter.

Angela Smith, "Mansfield and Dickens: I am not reading Dickens idly," Katherine Mansfield Society Annual Birthday Lecture, 1, 2010.

$8 \quad$ Richard Anthony Baker, British Music Hall (Gloucestershire: Sutton, 2005), 83.

9 Reserve Bank of New Zealand: rbnz.govt.nz/monetary-policy/inflation-calculator Accessed September 3, 2016. 
For several centuries London had been the epicentre for musical and theatrical "high culture." Opera, orchestral music, chamber music, Shakespearean performances and establishment theatres provided endless opportunities for the avid consumer of such offerings. Mansfield's education and life experiences were immersed in high culture and by the time she was 18 , she had a confident grasp of London's theatre, literature and music. Mansfield attended such events ${ }^{10}$ but other, more popular, forms of entertainment had evolved which Mansfield enjoyed immensely: music hall and cinema.

There is evidence that, unlike her contemporary Virginia Woolf, Mansfield was intensely interested in her work being widely known and recognised, and she understood that theatre was the most important art form at the turn of the century: "If you really want to be known in literature, you have to be on the stage, because the theatre is all the literature a lot of people know," wrote Edmond de Goncourt in $1892 .{ }^{11}$ He was referring to popular theatre: the theatre of the boulevards. Half a million Parisians (out of three million) went to a play once a week, and twice that number, writes Eugen Weber, went once a month: "The stage provided the primordial subject of conversation in society." 12 The potential audience was exponentially larger than those that read books. Whilst Weber referred to Paris, the same applied to London.

All of this Mansfield understood. She wrote in a letter to Garnet Trowell: "[I want] to write - and recite what I write - in a very fine way [it] would help popularise my work." ${ }^{\prime 3}$ In a later letter to Ida Baker, she revels in her success and aspires to become better known:

My agent has sold every single story of my new book in advance \& I have not written one. That's pleasant! My book has been a complete success, really. It has made it possible for me to publish stories anywhere I like, it seems...I intend to go

10 Notebooks: 1, 77-78. [Describes waiting for admission to a concert by violinist Fritz Kreisler.]

11 Eugen Weber, France Fin De Siècle (Cambridge, Mass: The Belknap Press of Harvard University, 1986), 272. Hereafter cited as Weber, France.

12 Weber, France, 159.

13 To Garnet Trowell, 4 November 1908, Letters, 1, 84. 
to London, take the Bechstein Hall and give readings of my stories... it would be a great advertisement. ${ }^{14}$

Music hall was the primary, popular expression of entertainment that Mansfield is known to have enjoyed, as did a significant cross-section of London's population. Quite how popular music hall singers were is illustrated by an 1872 obituary for an early music hall star, Harry Clifton:

The popularity which his songs attained is best denoted by the fact that even now they are whistled by every street-boy, played by every barrel-organ and sung in every town and hamlet in the United Kingdom. ${ }^{15}$

Brigid Brophy, relating two of Mansfield's experiences as a performer, wrote of her: "The obvious - indeed dazzling - talent...for multiple impersonation, through sketches whose form must be derived partly from her music hall turns." "Whether or not she did 'a turn' in one of them professionally has yet to be established, but she was clearly an enthusiastic attendee. Her diary entry of 26 February, 1915 reads:

In the evening went to the Oxford and saw Marie Lloyd who was very good [and the next day] Had supper with Kot and went to Pavilion after. Mlle Devanter sang. She is very good. [The day after that] Went to dinner and to the Chelsea Palace. ${ }^{17}$

Mansfield's desire for her work to be popular, as illustrated by the letter to Ida Baker mentioned in the first section above, makes sense of her use of many of the features of music hall and the dramatic arts, the primary popular entertainment of her time. These are explored in detail in Chapter Three, but what follows is an analysis of its appeal for her and other modernists, which gives context to her experience.

Singing had always been the mainstay of the music hall and in a letter to her husband, Mansfield wrote: "I did smile to find our song in your review."18 The

To Ida Baker, 30 April 1922, Letters, 5, 159-160.

The Era, 21 July 1872, cited by Baker, Music Hall, 13.

16 Brigid Brophy, "Katherine Mansfield's Self-Depiction” Michigan Quarterly Review, 5 (Spring 1966): 89-93.

$17 \quad$ Notebooks, $2,7$.

18 To JMM, 28 October 1919, Letters, 3, 54. 
song she alludes to is a music hall ditty which Murry referred to in a theatre review:

It's only a knockabout shanty

And furnished as plain as can be;

'Twas built with an axe and a hammer,

A bagful of nails and a tree.

The walls are not hung with old masters

Or furnished with fine tapestree;

It's only a knockabout shanty,

But it's home, sweet home, to me.

By the time Mansfield returned to London in 1908, song was still the core of music hall entertainment but it had evolved into a fluid and diverse offering which also incorporated dancing, male and female impersonators, aerial acts, juggling and illusionists. To give some idea of the variety, a poster for an evening in 1923 at the Empire of Newcastle-on-Tyne advertised:

Power And Bendon (The gaffer and his apprentice 'Mendin' a door,"; J.W. Rickby (Burlesque Character Comedian); Percy Honri (A concert in a turn); Marie Kendall (Versatile comedienne in her latest successes); Archie \& Gertie (In a few hard knocks); Bruce Green (The most talked of of dames, in latest songs and burlesques); Renee and Godfrey (England's leading young dancers.) ${ }^{19}$

In London, even more exotic fare was available:

If you wanted to see how London draws into its throbbing centre all the splendour, and wealth, and beauty in the world, you could not do better [than visit] one of the great music halls. All the wonders of the world are there, Indian jugglers, American cowboys, singers from Paris, dancers from St Petersburg, and Moscow and Berlin and the East. ${ }^{20}$

The origins of music hall were thought by some to be more ancient than theatre itself. Elizabeth R. Pennell, an art critic and scholar, published an essay in 1893 which made this claim:

19 Baker, Music Hall, 178.

20 G.H. Mair,"The Music Hall," The English Review, 1916. Cited by Barry J. Faulk, "Modernism and the Popular: Eliot's Music Halls," Modernism/Modernity 8 (2001) 612. Hereafter cited as Faulk, "Modernism and the Popular." 
Before the Miracle Play was invented, the people of England had clamoured for variety entertainment, and been given it. There was not a castle throughout the land that had not its own special London Pavilion or Alhambra in miniature...And the other turns boast a pedigree as illustrious and long. Acrobats and jugglers, bears and dogs, by the same feats and the same tricks - you can see them in illuminated manuscripts. ${ }^{21}$

As in the café-chantant in France, music hall was a working-class cultural form. The growth of each mirrors the other and was fuelled by the characteristics of the 20th century's "shrinking globe and new technologies for war, travel and information." 22 The liveliness and vigour of music hall was celebrated by eminent critics of the day, such as Max Beerbohm, ${ }^{23}$ who replaced George Bernard Shaw as critic for the Saturday Review. A little later, T.S. Eliot was also a fan of music hall and, like Pennell and Beerbohm before him, praised it as an expression of national character, the very "stuff of Englishness. ${ }^{, 24}$ Following the death in 1922 of Marie Lloyd, referred to earlier, Eliot wrote a eulogy:

Marie Lloyd was the greatest music-hall artist in England: she was also the most popular. And popularity in her case was not merely evidence of her accomplishment; it was something more than success. It is evidence of the extent to which she represented and expressed that part of the English nation which has perhaps the greatest vitality and interest. ${ }^{25}$

Modernist practitioners of all art forms borrowed from what was current and popular. As Barry J. Faulk pointed out:

It is commonplace to note that modernist works of art were tireless in citing items drawn from the popular, whether it was Picasso's inclusion of popular song titles (e.g. 'Ma Jolie'), Joyce's complex reworkings of music hall in Ulysses, or

21 Elizabeth Robins Pennell, "The Pedigree of Music-hall" (1893). Cited by Faulk, "Modernism and the Popular", 607.

22 Faulk, "Modernism and the Popular", 614.

23 Beerbohm wrote a series of essays for the Saturday Review, one of which, "The Older and Better Music Hall" (1903), lamented the commercial success of the form. Cited by Faulk, "Modernism and the Popular", 609.

24 T.S. Eliot, "London Letter" The Dial. Cited in Faulk, "Modernism and the Popular", 611. 25 Ibid. 
Weill's adaptations of contemporary jazz in Die Dreigroschenoper. ${ }^{26}$

Mansfield conflates both ideas in "Je ne Parle pas Français (1918) where she appropriates a popular song and makes it function as an emblem of nationality. Dick Harmon's song about hardship ("One Fishball"27) is used to illustrate Englishness:

"It seemed to hold, in its gravity and muffled measure, all those tall grey buildings, those fogs, those endless streets, those sharp shadows of policemen that mean England," says Raoul. "How profound these songs are! There is the whole psychology of a people; and how un-French - how unFrench!"28

An important part of music hall and of Marie Lloyd's act in particular was double entendre:

Lloyd, the legend goes, was once called before the Licensing Committee of the London County Council and asked to perform a song whose lyrics had caused complaint. She proceeded to perform the number without elaboration and won the committee's approval. Then she immediately launched into the innocuous parlour ballad, "Come into the garden, Maud" by Alfred Lord Tennyson, giving it a thoroughly lascivious rendition. $^{29}$

Double entendre was a talent Mansfield also enjoyed and deployed. Frederick Goodyear, in one of his letters to Mansfield, mentioned how "he greatly missed her talent for double entendre, which made conversation with her one of the consolations of life." 30 An example of Mansfield's use of double entendre in her work is the final word of "The Man Without a Temperament" (1920):“"Rot!' he whispers." "31 The reader can interpret this as meaning "Nonsense!" or, more sinisterly, an instruction to his ailing wife to let herself decay. Mansfield employs double entendre but wrests it from the vulgarities of

26 Faulk, "Modernism and the Popular", 603.

27 In fact, "One Fishball" was composed by George Martin Lane (1823 -1987) who was a Professor of Latin at Harvard University and based it on a personal experience. Cited in Harvard Magazine, "Song for Hard Times" by Primus, May-June 2009.

28 KMCS, 70.

29 Faulk, "Modernism and the Popular", 616.

30 Letter from Frederick Goodyear to KM, 14 February 1916, ATL.

$31 \quad K M C S, 143$. 
music hall sexual innuendo and forges it into something powerful and threatening, making the word itself perform twice over. Music hall was not the only inspiration for the use of double entendre. Oscar Wilde, whose influence on Mansfield is the subject of one of Vincent O'Sullivan's critical works ${ }^{32}$ used it as part of his word play. Others writers, such as Rudyard Kipling, were also skilled practitioners of this form of punning.

The most famous and popular music hall singers did not necessarily have beautiful voices. ${ }^{33}$ The skill of Marie Lloyd and similar performers, like Florrie Forde and Elsa Lanchester, was their ability to create a character for each of their songs and to create a voice for that character. It was a skill that evolved from a long tradition of musical theatre. When Elsa Lanchester sang "When a Lady has a Piazza," she sounded like a rather exhausted, depressed gentlewoman, causing a critic to comment: "There is a desperate quality about her art; in some curious way, she takes her listeners out of a close, tidy world and into a disquieting place filled with sharp winds and unsteady laughter."34 This immediate, deft and dramatic ability to convey character through voice, music, lyric, gesture and innuendo can be seen in Mansfield's technique, explored in Chapter Three.

Mansfield and Eliot shared an appreciation of other features of music hall, such as accents, which they used in their work. The imitation of exotic accents and renditions of various British ones was a staple of music hall songs and comedic sketches. According to Ida Baker, ${ }^{35}$ the skits Mansfield performed at West End soirées were delivered in an Irish or Cockney accent and these were her first paid performances, which are detailed in the next section. Her frequent use of accents in her stories will be analysed in the following chapter. Mansfield named her cat, Wing Lee, after the title of one of her favourite music hall songs, "Wing Lee's Ragtime Clock," the lyrics of which manage to offend

\footnotetext{
32 Vincent O’Sullivan, “The Magnetic Chain: Notes and Approaches to KM,” ed. Pilditch, Critical Response, 137.

33 Elsa Lanchester, A Gamut of Girls: Memoir "I am not first and foremost a singer." Cited in "Elsa Lanchester, a Cause of Lasciviousness in Others," Max Sparber, ukuleleking.diaryland.com/copyright. Accessed July 23, 2016.

34 Ibid.

35 LM, Memories, 39.
} 
today's sensibility regarding not only one, but two racist stereotypes and which illustrates the use of accents:

1st line: Wing Lee bought a clock the other day, just because it kept ragtime Wing Lee bought a clock the other day, he considered it no crime

$I^{\text {st }}$ line, chorus: No like ragtime, no like coon, all lookee same to me, shouted poor Wing Lee. ${ }^{36}$

Eliot uses a cockney accent in a section of The Waste Land: When Lil's husband got demobbed, I said/ I didn't mince my words, I said to her myself/ HURRY UP PLEASE ITS TIME/ Now Albert's coming back, make yourself a bit smart. ${ }^{37}$

Mansfield might also have appreciated another aspect of music hall which Eliot also outlines in the eulogy to Marie Lloyd:

The working-man who went to the music hall and saw Marie Lloyd and joined in the chorus was himself performing part of the work of acting; he was engaged in that collaboration of the audience with the artist which is necessary in all art and most obviously in dramatic art. ${ }^{38}$

Participating as an audience member is clearly performative, but for Mansfield observing an audience was also like observing a performance, which is illustrated by a journal entry:

Went to Hippodrome. The audience - their heads and hands were the only thing worth watching. In the gloom they seem so remote, so infallible in movement. Went to Pantomime. Very interesting. Began to think of Panto tradition. Would like to write in it. ${ }^{39}$

In the tradition of British pantomime, audience participation is a fundamental part of the experience. In Mansfield's story "Daphne" (1921) the young male

\footnotetext{
36 “Wing Lee's Ragtime Clock," Al Trahern (composer) (New York: Myll Bros, copyright 1899).

37 T.S. Eliot, The Waste Land (London, Faber \& Faber, 1975), 56 [First published in 1922.]

38 T.S. Eliot, "London Letter." Cited in Faulk, "Modernism and the Popular", 611.

39 Notebooks, 2, 3.
} 
narrator describes an evening at the theatre in "Port Willin" (Wellington) which conveys the performative power of an audience itself:

I found it, for some reason, fearfully exciting. The inside smelt of gas, of glue and burnt paper...In the intervals long ripples of laughter sounded from the stalls, from the dress-circle. And I leaned against a pillar that looked as though it were made of wedding-cake icing - and fell in love with whole rows at a time $^{40}$

Relating to an audience is an intrinsic part of performance and being a performer. In the two examples above, she describes audiences attending a performance as a performance itself. Mansfield's engagement with music hall and theatre offered her a model of the ways in which an audience can be made to feel part of the action. The "mash-up" quality of the music hall experience, where one comic act using a Cockney accent was followed by a song of great sincerity and sweetness, has parallels in the construction of her stories. Her use of more mechanical devices, such as sound effects (music, voice, accents, song and onomatopoeia) and dialogue, as well as visual effects such as costume changes and costume props, are fully explored in Chapter Three.

As outlined at the beginning of this chapter, accounts of Mansfield's performances include those that were both paid and unpaid and both form the basis of this thesis. That said, the fact that she was, at times, employed as a performer does strengthen the credibility of the argument that performance played a significant role in her life. It demonstrates that it was more than whimsy on Mansfield's part and her talent was sufficiently robust to be recompensed. In this section, both her paid and her unpaid performances will be examined. The instances where it is reasonable to assume that Mansfield was paid to perform include: West End society hostesses' soirees; the chorus of the Moody Manners Opera Company and her appearances at the Cave of the Golden Calf and the Cave of Harmony. The most likely unpaid, but public performances with her husband, George Bowden, are covered as well as her performances with friends at private homes. Her work as a film extra is analysed in a separate section.

$40 \quad K M C S, 462$ 
Like Colette, whom she admired and whose talent for scandal outdid her own, Mansfield started working as a performer in private salons and subsequently moved into public performance spaces. Mansfield's performances at West End society soireés came about through her lodgings. Despite her parents' veto of a musical career, they had approved her living at Beauchamp Lodge in Paddington, a hostel for young female music students run by two professional musicians, Miss Ann Muckle and Miss Rosabel Watson. She described the environment:

\begin{abstract}
Above me a woman is practising the drums - not an inspiring instrument. It sounds like the growling of some colossal dog, and I know I shall have dreadful nightmares ... Oh, dear, next door someone has started scales on the trombone - curiously like a Strauss Tone Poem of Domestic Snoring. ${ }^{41}$
\end{abstract}

She had, however, accepted her family's stricture that a professional musical career was out of the question. To become a writer was her professed ambition and one that was seemingly acceptable to her parents, but performance also appealed. LM described the early forays:

Katherine was able to use her great gift for recitation, mimicry and music, as in those days hostesses often provided entertainment for their guests. When Katherine's gift was discovered through the friends she had made at the lodge, she was soon offered professional invitations, at a guinea an evening. These were tempting propositions and she accepted a number of them. ${ }^{42}$

Mansfield was not only performing, but also writing her own work. The audience was initially small. Margaret Wishart, a friend from Beauchamp Lodge days, recalled Mansfield writing "masses of short stories, which had to be read aloud to me for criticism., ${ }^{43}$

To Garnet Trowell, 23 September 1908, Letters, 1, 62.

LM, Memories, 40.

Crone, Portrait, 69. 
The West End engagements took place from August 1908 to March 1909, when Mansfield was resident at Beauchamp Lodge. She married George Bowden on 2 March 1909, left him that night, quit Beauchamp Lodge and from $10^{\text {th }}$ to $28^{\text {th }}$ March joined Garnet Trowell who was touring with the Moody Manners Opera Company as a violinist in its orchestra. Various sources corroborate that this episode was Mansfield's second known spell as paid performer. First, LM:

Quite soon an opportunity came for Garnet to get paid temporary work with a small touring opera company. He could obtain a little part for Katherine in the chorus, but, because of accommodation difficulties, only by saying she was his wife. ${ }^{44}$

Mansfield also entertained John Middleton Murry with accounts of this time of her life, telling him:

How [she and Garnet] used to cook themselves kippers over a fishtail gas flame in their boarding house, and how she sang in the opera chorus, and learned all the absurd gestures that an opera chorus had to make in those days. ${ }^{45}$

Mansfield's presence in the chorus of the Moody Manners Opera Company cannot be discounted as a high-spirited frolic of little performative significance. Despite the somewhat comedic quality of its alliterative name, the Moody Manners Opera Company was the precursor of the English National Opera. Its founders, Charles Manners and his wife Fanny Moody, were professionals of influence. The opera historian, Harold Rosenthal, has written of the company that: "it was the principal training ground for British artists in the years before World War I."46

Mansfield's brother-in-law, Richard Middleton Murry recounted how one day, when he was visiting his brother and sister-in-law at Portland Villas in Hampstead, a neighbour brought his gramophone out into his garden and played operatic recordings. Mansfield knew all the material, went to the

\footnotetext{
$44 \quad$ Baker, Music Hall, 44.

45 Alpers, Life, 92.

46 Harold Rosenthal, "Mood-Manners Opera Company", Oxford Music Online (requires subscription). Accessed July 23, 2016.
} 
window and mimed along to the music. She struck Richard as: "a true entertainer and extrovert...very enmeshed with life."

Rebecca West recalled that in 1913 she saw Mansfield perform at the Cave of the Golden Calf and Vera Brittain ${ }^{48}$ noted that Mansfield also gave performances at a club, the Cave of Harmony. Both these places serve to illustrate how avant-garde Mansfield was and the circles in which she socialised and performed. Rebecca West wrote to Anthony Alpers about her experience:

I saw KM only once, when she was commère at a cabaret show in Regent St, run by one of Strindberg's wives. She looked very pretty in a Chinese costume. She was very attractive, with her beautiful dark hair [and] introduces the acts and performs some of her own sketches. ${ }^{49}$

The Cave of the Golden Calf was situated in Heddon St, off Regent St, and was opened in 1912 by Frida Strindberg, a wealthy bohemian who had been married to the playwright, August Strindberg. She envisioned it as the London equivalent of the Kabarett Fledermaus of her native city, Vienna, bringing the European concept of cabaret to London. Its manifesto stated:

Our aims have the simplicity of a need. We want a place given up to gaiety, to a gaiety stimulating thought rather than crushing it. We want a gaiety that does not have to count with midnight. We want surroundings, which after the reality of daily life, reveal the reality of the unreal. ${ }^{50}$

Philip Hoare in his book, Oscar Wilde's Last Stand, described how this manifested itself:

Up in Regent Street young men wearing tight suits and nail varnish were sipping crème de menthe in the Café Royal, while down a dark cul-de-sac lurked a new and devilish sort of place where Futurists cavorted: a 'night club' profanely named 'The Cave of the Golden Calf...the backstreets harboured all manner of such places, attended by members of the social elite. Such intimations confirmed all the suspicions of her class. At the root

47 Richard Murray, "Katherine Mansfield," Radio Times, 4 July 1973.

48 Vera Brittain, Radclyffe Hall: A Case for Obscenity? (London: Barnes, 1959), 95.

49 Meyers, A Biography, 37.

50 Richard Cork, "The Cave of the Golden Calf," Artforum, XXI (December 1982): 55-68. 
of these evils lay the name of Oscar Wilde, still unspoken in polite households. He may have been dead for more than a decade, but Wilde's decadence endured. ${ }^{51}$

Strindberg hired Jacob Epstein and Wyndham Lewis to decorate the club, which they did with "primitive" murals, in the manner of Gauguin of Tahiti. The club attracted the wealthy, the artistic and the bohemian along with "the mad, bad and decadent." 52 Some of its eclectic scope is conveyed by a preview in The Times:

On the opening night there will be dances from Goya's 'Caprichos', Morris and hieratic dances, and a scene from a Breton 'Wake' of quite Hogarthian character. Spanish gypsies will sing their old mysterious lore - a feature entirely new to any English stage. The reigns of Charles II and the Georges will supply each their particular quota of mirth and song. The more serious note will be struck in works by Bantock, Delius, Lapara, Fried, Mistral, Moret and in the form of modern English poetry drama and satire.

The opening night performances [will also include] songs by the Norwegian singer Bokken Larsson. ${ }^{53}$

The clientele could enjoy a variety of performances including song, music and dance and drink until dawn. It closed due to bankruptcy in 1914. In 1915, Margaret Morris and her partner, Scottish painter J.D. Fergusson (Creative Editor of Rhythm), founded the Margaret Morris Club in Flood Street in Chelsea. It quickly became the focus for the remnants of the avant-garde in London, including Mansfield, but there is no evidence of her having performed at it.

$51 \quad$ Philip Hoare, Oscar Wilde's Last Stand (New York: Arcade, 1997), 217.

52 Jaap Harskamp, "Underground London: From Cave Culture Follies to the Avant-Garde," British Library Journal, 7 (2009). Also the source for material on the Cave of Harmony. Hereafter cited as Cave Culture.

53 The Times, June 1912. 
It has been mentioned that Vera Brittain noted that she saw Mansfield performing at a club called the Cave of Harmony ${ }^{54}$ (a $19^{\text {th }}$ century euphemism, more literary than colloquial, for the vagina). It was started by female impresario Elsa Lanchester after World War I. Lanchester is best known as the "Bride of Frankenstein" in the film of the same name, which was made in 1935. She was the daughter of unmarried parents who were active socialists and non-conformists. Her nightclub featured cabaret-style turns and semiimprovised modern plays. Lanchester herself specialised in reviving Victorian songs, such as "Please Sell No More Drink to My Father"; "He Didn't Oughter"; "Don't Tell My Mother I'm Living in Sin" and "The Ladies Bar." Like Marie Lloyd, she revelled in double entendre, with songs such as "If You Peek In My Gazebo" and "Fiji Fanny." A song was written about her, which illustrates the hectic nature of her personality and enterprise:

I may be fast, I may be loose, I may be easy to seduce.

I may not be particular

To keep the perpendicular.

But all my horizontal friends

Are Princes, Peers and Reverends.

When Tom or Dick or Bertie call,

You'll find me strictly vertical! ${ }^{55}$

After her time with the opera company and following her subsequent eight months in Bavaria, Mansfield returned to London and, for a brief period, lived with her husband, George Bowden. Anthony Alpers' biography of Mansfield provides an outline of the relationship. ${ }^{56}$ Bowden, eleven years Mansfield's senior, was a singing and elocution teacher. He had been at King's College, Cambridge on a choral scholarship and was a contemporary of E.M. Forster there. Murry later dismissed him:

He had advanced into the profession by the flowery path of a choral scholarship at Cambridge. He had education and refinement; he was the gentleman artist with the bedside

$54 \quad$ www.sex-lexis.com/Sex-Dictionary/Cave, Accessed September 12, 2016.

55 In her posthumously published A Gamut of Girls: Memoir (1988), Lanchester attributes the song to a local (unnamed) journalist. Cited in Cave Culture, 7.

56 Alpers, Life, 85-105. 
manner of the type afterwards depicted with subtle understanding in "Mr Reginald Peacock's Day."57

There is nothing particularly "flowery" about a choral scholarship to Oxford and Cambridge, then or now. Choral scholarships are a longstanding tradition which seeks to usher students with musical gifts onto an academic pathway. In an unpublished letter, Bowden himself rejected this portrayal, writing to Murry after the Mantz-Murry biography had appeared, that he thought: "she found in me a congenial and sympathetic response to her literary enthusiasms and ambitions." singing and speech training at the London College of Divinity, and also gave singing lessons in a studio in Bond St. This was his situation when he met Mansfield and her interest in elocution, already outlined, may have been part of the attraction. She found his voice "caressing." 59 During the couple of months that she co-habited with him, he arranged for her to perform:

She went to his studio in Bond Street once or twice, and "sang a little." She collaborated with him in a concert he gave at one of the institutions where he lectured, "delighting a large audience by her recital of some of her sketches." 60

Ida Baker, herself musically trained, said Mansfield had a "pure, high soprano." 61 It is unknown whether she was paid for any performances with her husband. What is noteworthy is that, as a professional himself, it seems unlikely Bowden would have organised for her to perform if he did not think her abilities were of a professional standard. That she was able to achieve this standard, without any training other than that she received at school, is indicative of her inherent talent. George Bowden also suggested the New Age as a vehicle for the stories she had written. The first she submitted, "The Child Who Was Tired" (1910), was accepted. Her career as a published writer began and performance was relegated to a secondary role. It was still the default option if she needed to earn more money.

\footnotetext{
57 Ruth Mantz and John Middleton Murry, The Life of Katherine Mansfield (London: Constable, 1933), 319.

58 Cited in Alpers, Life, 107.

59 Alpers, Life, 106.

60 Alpers, Life, 105. Citing Bowden, "A Biographical Note on Katherine Mansfield." (1948).

61 LM, Memories, 36.
} 
The social circle she and Murry developed with friends and colleagues after meeting in 1911 was literary but also theatrical, and none was more so than the artist Mark Gertler, as Beatrice Campbell wrote:

Gertler was a great source of entertainment to us with his wonderful story-telling. He loved to act with his stories, imitating everyone...Gertler would go out of the room and return as Lady Ottoline Morrell, then as one of the Stracheys or Sitwells or Maynard Keynes or some other, making himself fat or tall, short or thin, while we all laughed helplessly...He loved music-halls and would give imitations of the turns that he saw there. ${ }^{62}$

Murry himself wrote a play, "Cinnamon and Angelica,"63 as did Clive Bell, "Love and Liberty." 64 Using their social circle as material for characters in their novels, plays or simply as fodder for gossip characterises Bloomsbury and its outreaches more than most identifiable literary groups. They also entertained each other with charades and performed in little plays. Accounts of these occasions often occur around Christmas time, and Gertler was at the centre of one of Mansfield's best known life performances in 1914. Christmas Eve was spent with the Lawrences:

Katherine "with a long ridiculous face" sings some music hall songs which Frieda loves, but Lawrence condemns as "too fast". 65

At a Christmas party at Gilbert Canaan's Mill House that year, the guests performed a play that dramatised the difficulties of Katherine and Murry. Mark Gertler was cast as Murry's rival, and when they reached the moment when Katherine was supposed to leave Gertler and return to Murry, she refused to follow the script and remained with Gertler. The painter wrote to Lytton Strachey and Dora Carrington:

62 Beatrice Campbell, Lady Glenavy, Today we will Only Gossip (London: Constable, 1964), 79. Hereafter cited as Glenavy, Gossip.

63 JMM, Cinnamon and Angelica (London: Cobden-Sanderson, 1920).

64 A farcical comedy in three acts. It was unpublished and unperformed. Mentioned in a letter from Virginia Woolf to Clive Bell, 9 April 1921, The Letters of Virginia Woolf, (London: The Hogarth Press, 1976), 2, 519.

65 Tomalin, A Secret Life, 132. 
I got so drunk that I made violent love to Katherine Mansfield! She returned it, also being drunk. I ended the evening by weeping at having kissed another man's woman and everybody trying to console me ... No one knew whether to take it as a joke or a scandal. ${ }^{66}$

As outlined at the beginning of this chapter, Mansfield viewed theatre as a way of becoming well known, and, as evidenced by this journal entry, as a way of making good money. In March 1914, she wrote:

Jack would think me really important if I brought him L.S.D. [pounds, shillings and pence.] He thinks he's far and away the first fiddle. How he'd love to boast of what I got out of a play. That's why I'm going to start one today. I'll sweat my guts out till I bring it off too. ${ }^{67}$

In June 1917 Mansfield gave a reading of Eliot's poem "The Love Song of J. Alfred Prufrock" at Garsington:

Clive Bell came back from town with several copies, which he handed round (he mistakenly says it was Easter) "like so many Good Friday buns." "Prufrock" itself caused a stir, he says, and much discussion, and of one thing he was sure: "It was Katherine Mansfield who read the poem aloud."68

Mansfield later made the observation to Virginia Woolf that she didn't think of Eliot as a poet, because "Prufrock is, after all, a short story.", 69

Eliot's work The Waste Land was not published until 1922. The Waste Land, with its multiple voices, accents and rhythms contains elements of dramatic form. Its original title He Do The Police in Different Voices was taken from Dickens' Our Mutual Friend. An interesting idea which links Eliot and Dickens more deeply has been raised by German scholar Ludwig Borinski, who thinks Our Mutual Friend can be seen as Ur-Modernist text:

Everywhere at that time strict realism is in vogue, depicting with exactitude the minutest details of everyday life (in England, in the work of George Eliot and Trollope, for example). By contrast Dickens strides forward at this point to

Mark Gertler, cited in Alpers, Life, 77-8.

Notebooks, 1, 282.

Alpers, Life, 239.

Cited in Alpers, Life, 239. 
full-blown Impressionism [...] Dickens' surrealistic animation of things and comparisons that boldly but most powerfully bring together non-logical incongruities, as in the art of T.S. Eliot and James Joyce. ${ }^{70}$

Katherine Mansfield can be added to Eliot and Joyce. Mansfield wrote to Brett about Christmas, 1918:

it had been...superb - stockings - a tree, decorations, crackers, pudding, drink - most potent and plentiful - parcels pouring in and out. Murry seemed to wear a paper hat (a large red and yellow butterfly) from Christmas Eve until after Boxing Day We gradually, under the influence of wine and Chinese mottoes gave a party - Charades - Kot, Gertler, Campbell etc. Oh, I did love it so - loved everybody...the red chairs became a pirate ship. Koteliansky wore a muff on his head and Campbell a doormat tied under his chin. ${ }^{71}$

Such a description reinforces the sense that Mansfield's milieu was theatrical: they acted charades; dressed up (in what sounds like absurd, rather than enhancing costumes) and played, for the sheer fun of it. In an unpublished letter to a friend in New Zealand, Frances Cornford, the poet and granddaughter of Charles Darwin, referred to a "performance" of Katherine's:

My sister Fredegond described to me once meeting KM in her earlier Bloomsbury days at a tea party [c.1917]. KM came in late and described most brilliantly how she'd been shopping acting the whole conversation with the shop woman. But yet it was just a little vulgar, a little vain \& strung up, a little unkind. ${ }^{72}$

Lady Glenavy recounted another instance of Mansfield's readiness to "play":

70 Ludwig Borinski, "Dickens' Spätsil, [Dickens's late style]" (1957). Cited in Introduction, The Reception of Charles Dickens in Europe, ed. Michael Hollington (London: Bloomsbury, 2013), 5.

71 Crone, Portrait, 234.

72 Frances Cornford to Irene Wilson, 1 September 1929, Cornford MS papers 269, ATL. 
Katherine and I found ourselves wandering round the large drawing room examining pictures and furniture, and she said softly to me "Do you feel that we are two prostitutes and that this is the first time we have ever been in a decent house?" I knew she was acting a part and wanted me to join in the game. It had been raining on our way there and we were rather damp and bedraggled, which helped the illusion. ${ }^{73}$

Accounts of Mansfield as a performer, public or private, cease from early 1918, when she was diagnosed with tuberculosis. There is one, however, from 1922, when she was at The Gurdjieff Institute for the Harmonious Development of Man. A young Lithuanian woman, Adela Kafian recounted:

Then came Christmas. We all gathered around a huge illuminated Christmas tree. There were many children in the house as some of the inmates had families. Mrs. Murry came down into the drawing rooms, looking very attractive in a dark purple taffeta dress, embroidered with tiny flowers; the dress was simply cut with shoulder straps as young girls wear. Her short hair was smoothly combed over her high forehead. With great interest she watched the children receiving presents, and afterwards recited some character-scenes in an English dialect. I did not understand the words, but it was interesting to hear the sharp changes in her voice, suggesting peasants quarrelling among themselves. The whole company surrounded her; the children without understanding the words, smiled at the expressions of her face, and the changes in her voice. ${ }^{74}$

At the end of her life, Mansfield demonstrated the rightness of her statement in her letter that she had "the power of holding people" and that "Tone should be my secret - each word a variety of tone."75 In Kafian's account, the words, aren't understood by many in the audience. It was her expressions and tone, the "changes in her voice," that conveyed meaning.

In life Mansfield also "performed" and there are various accounts from contemporaries of Mansfield describing her performance qualities. Aldous Huxley wrote:

Glenavy, Gossip, 80.

Adela Kafian, "The Last Days of Katherine Mansfield," New Adelphi, 1946. Cited in Alpers, Life, 382.

To Garnet Trowell, 23 September 1908, Letters, 1, 62. 
She was an unhappy woman, capable of acting any number of parts but uncertain of who she really was...she was a series of points and arcs on the circumference of a circle that was uncertain of the location of its centre. ${ }^{76}$

Huxley evidently brought out her sense of drama. In a letter to Lady Ottoline Morrell, who, having received a letter from Huxley about the Café Royal incident, ${ }^{77}$ asked for Mansfield's account:

Heavens! His letter (Huxley's) makes me feel so old - and inclined to dress up, alone in the studio here - Tie my head up in a turban, make myself fat, don a fur coat with lace frills slightly spotted for tea, and act Lady Mary Wortley Montagu receiving a morning leg from - Swift perhaps ${ }^{78}$

Leonard Woolf was a more receptive audience:

I don't think anyone has ever made me laugh more than she did in those days. She would sit very upright on the edge of a chair or sofa and tell at immense length a kind of saga, of her experiences as an actress... There was not a shadow of a gleam of a smile on her mask of a face, and the extraordinary funniness of the story was increased by the flashes of her stringent wit. $^{79}$

Edmund B. d'Auvergne, a contributor to the New Age, recalled that after inviting its editor, Arthur Orage, Beatrice Hastings and Mansfield to dinner that summer, he felt that Katherine "was like an actress trapped in comic roles - she had to sustain the part she had created in her sketches." 80 This suggests Mansfield's dramatic persona was an unwitting by-product of her creative work. Conversely, the next chapter illustrates the crux of this thesis: that how she created her sketches was due in large part to her using her skills and experience as an "actress."

76 To Allan J. Crane, 27 January 1963, Grover Smith collection of Aldous Huxley correspondence, 1908-1985, MS 462, Woodson Research Center, Fondren Library, Rice University.

77 Mansfield, offended by people at a nearby table mocking the poetry of D. H. Lawrence, went over to them, asked for the book, and without another word, left. Alpers, Life, 216.

78 To Lady Ottoline Morrell, Letters: 1, 280 [Montagu was an $18^{\text {th }}$ century bluestocking famous for her travels in the East.]

79 Leonard Woolf, Beginning Again 1911 - 1918 (London: Hogarth Press, 1964), 203-4.

80 Interview 5 July 1954, Edmund B. d'Auvergne with Anthony Alpers. Cited in Life, 116. 
From 1913 to 1917 Mansfield occasionally acted in the cinema. From the information we have, it seems that she was employed as an extra. In her 1915 journal there is reference to meeting "a woman who had been in the cinema with me - her old yellow teeth and pink roses in her hat \&...lovely eyes and battered hair. I shall not forget her $-\underline{\text { no }} \underline{\text { no" }}$, and Ida Baker recalled:

She became particularly anxious to earn. I remember going with her for an audition to some agent who was offering small walking-on parts in the films. It all seemed very sordid and I don't think Katherine even tried it; the pay, too, would have been negligible. I waited for her at the entrance and when she came out she was discouraged and tired and her description of the man at the desk made him sound entirely unpleasant. ${ }^{82}$

However unpleasant the incident referred to might have been, there are further references to her working in cinema. Early in 1917 she wrote to Bertrand Russell: "Tomorrow I am acting for the movies - in 'exterior scene in walking dress", ${ }^{83}$ In another letter to him not long after she added: "My last day with the 'movies' - walking about a big bare studio in what the American producer calls 'slap-up evening dress' has laid me low ever since.",84

Anne Estelle Rice remembered meeting Mansfield looking "strangely different". ${ }^{85}$ Rice was told that she [Mansfield] had been acting in a film, had just jumped off the Battersea Bridge and was rescued by the hero of the film. Such a role could have been that of a stunt double for a lead actor. What gives this story some credibility is that Mansfield was a proficient swimmer, having spent many hours in the Thorndon Baths in Wellington. Looking "strangely different" was a forte of Mansfield's and illustrates how she employed costume changes in real life situations. Rice met Mansfield in 1906 in Paris when she was working there as an illustrator and recalls Mansfield appearing at the Closerie de Lilas in Paris on different nights in wildly varying guises: "now a coat covered in cherries, another time a cloak and a white fez, or a

Notebooks, 2, 217.

LM, Memories, 86.

To Bertrand Russell, 16 January 1917, Letters, 1, 291.

To Bertrand Russell, 21 January 1917, Letters, 1, 293.

All references by Anne Estelle Rice are from "Memories of Katherine Mansfield" Adam International Review, 300 (1965), 84. Hereafter cited as Rice, "Memories of KM". 
turban, with a bright, red-lipsticked mouth." They resumed contact in London and Rice recalled that: “"The Tigers' [Katherine and Murry] used to go down the Strand in cowboy shirts and a swaggering gait pour épater les bourgeois $" 86$ and that Mansfield would creep up behind New Zealand soldiers in London and let out a Maori war cry.

All the experiences outlined in this section illustrate the breadth of Mansfield's experience and her identification with performance culture. There was another, visible identification that is worthy of note: her wearing of make-up. The popularity of theatre and actresses led to the trend of young women seeking to emulate them by wearing makeup. ${ }^{87}$ There are several references to Mansfield wearing makeup and she would have been more familiar with it than many of her contemporaries because of her theatrical experiences. An early adopter in many ways, her use of it clearly stood out, as this account from Anne Estelle Rice conveys:

I well remember the impact of a compelling and vivid personality. Unforgettable was the round, oval face like ivory, the nose, full face - how shall I describe it? Two dots indicating the nostrils gave its position, and her mouth was a blob of cosmetic scarlet. ${ }^{88}$

The wearing of such make-up provoked heated reactions. Rupert Brooke recounted the following in a letter to his patron, Eddie Marsh:

Katherine [Tiger] Mansfield is in the country. She got turned out of an omnibus the other day for calling a woman a whore. She really ought to remember that she's a lidy (sic). The provocation was that the woman said all suffragettes should be trampled to death by horses. Katherine tho' not a suffragette protested, and the woman said "You with your painted lips". Rather a squalid little story. ${ }^{89}$

Virginia Woolf also commented on Mansfield's make-up in a letter to Violet Dickinson:

Rice, "Memories of KM", 89.

Linda M. Scott, Fresh Lipstick (New York: Palgrave Macmillan, 2005), 204.

Rice,"Memories of KM", 87.

Christopher Hassall, Edward Marsh: Patron of the Arts, (London: Longmans, 1959), 226. 
You thought her too painted and posed for your more Spartan taste I think. But she is all kinds of interesting things underneath, and has a passion for writing, so that we hold religious meetings together praising Shakespeare. ${ }^{90}$

Put together, her known experience encompassed: solo professional appearances singing and delivering sketches in various accents; working in a professional opera company's chorus (which combines both acting/miming and singing); appearing both as $\mathrm{MC}$ and performer in the avant-garde clubs of London; singing and recital performances with her first husband, who was a professional elocution and singing teacher; many instances of impromptu and rehearsed performances amongst her social and professional circle and working as a film extra. In the context of Mansfield's brief life, this constitutes a significant body of work. Other than writing, she had no other known paid, or unpaid work. It is a persistent and dominant thread and its influence is examined in the next chapter.

90 The Letters of Virginia Woolf, 12 August 1919 (London: The Hogarth Press, 1976), 2, 382-3. 


\section{CHAPTER THREE: MANSFIELD'S USE OF STAGECRAFT}

"I want lights, music, people"1

In 1911, Mansfield wrote a piece which illustrates how avid a theatregoer she was at this time and how theatre stimulated her performative senses. The theatrical event "Sumurun" opened in January at London's Coliseum for six weeks. Leopoldine Konstantin was the name of the actress who played the key role of the Dancing Girl in German director/producer Max Reinhardt's adaptation of the Arabian Nights. His inherently Symbolist outlook is evident in a dictum which expressed Mansfield's own modus operandi: "Always act the part - and you can become whatever you wish to become!"2 and this production represented the apogee of his Symbolist work. "Sumurun" had international success, greatly helped not only by its exotic and sensual content, but also by it being a virtually wordless spectacle, employing pantomime, music and dance. It took London by storm and Mansfield with it. Mansfield's work was titled: "SUMURUN" by KM - An impression of Leopoldine Konstantin."3 Mansfield's text is essentially a partial description of the production, its first paragraph setting the scene:

She opens the iron barred window and leans out. Below her the hunchback sits on the stage thrumming his guitar, and the old comic woman, the snake charmer, and the little, fantastic audience, stir and cry aloud with the gestures and voices of dolls. $^{4}$

Mansfield goes on to observe the lighting and staging techniques:

The room behind her is quite dark but a bright light shines on her dusky face and hair, on her shimmering green dress and bare, brown arms. ${ }^{5}$

And her own interpretation of the actor's intent:

Glenavy, Gossip, 71.

www.azquotes.com/author/49209-Max_Reinhardt. Accessed August 22, 2016.

ATL, MS-Papers-11327-048.

Ibid. 1.

Ibid. 
One thinks of a bird quivering a moment in the open door of a cage - there is just that wild eagerness about her ${ }^{6}$

Followed by another, powerful response to the work and the idea of theatre itself:

From some unseen place - some dark corner you know nothing of $-\mathrm{a}$ whistle is heard. Her body stiffens - she lifts her head, triumphantly smiling, and at her smile you feel like a child who is at the theatre for the very first time and that everything wonderful and glorious is going to happen ... you feel she is perfectly justified in wanting to kill that old, sleeping figure you want to cry "hush" yourself when she is alarmed - you refuse to believe that the hunchback could be so cruel. ${ }^{7}$

Such a powerful response was not confined to expression only in writing but also to acting. Performance of all kinds captivated Mansfield, whose taste ranged from music hall to opera, jazz and ragtime to classical music. She used performative imagery in her letters to illuminate ideas about life, people, and their situations, such as one to Lady Ottoline Morrell in which she declared herself:

quite overcome, for the $n$th time by the horror of life - the sense that something is almost hopelessly wrong. What might be so divine is out of time - or the instruments are all silent and nobody is going to play again. There $i$ s no concert for us. Isn't there? Is it all over? Is our desire and longing and eagerness, quite all that's left? Shall we sit here forever in this immense wretched hall - waiting for the lights to go up which will never go up. ${ }^{8}$

Her viewpoint in this letter is that of a third party observing 'us' as a group including herself, Lady Ottoline, their friends and, more widely, their generation, as spectators, or an audience. In another letter, she called her stories "regular performances."

ATL, MS-Papers-11327-048, 1.

ATL, MS-Papers-11327-048, 2.

To Ottoline Morrell, 24 July 1921, Letters, 4, 235.

Notebooks, 2, 226. 
Given the argument that theatrical experience influenced her writing, it needs to be noted that any evidence of her writing a full play is scant. She wrote to Lady Ottoline Morrell:

My play, which is called "A Ship in the Harbour", is at its Third Act. I hope it will be good; I know the idea is good. But there is an unthinkable amount of pruning to be done before one can liberate one's people in a play. I hadn't realised it before. It is very hard work. ${ }^{10}$

This was published later as "Toots." Other than this, there is only one manuscript of a play written by Mansfield. Morrell had invited her to stay at Garsington for Christmas in 1916. Her fellow guests included Bertrand Russell, Maria Nys, Dora Carrington, John Middleton Murry, Lytton Strachey, Dorothy Brett, Aldous Huxley and Clive Bell. On Boxing Day, Mansfield wrote "The Laurels," a playlet for the house party to perform. It was performed on Boxing Day evening. Dora Carrington told her brother it was "marvellously witty, and good," 11 and Aldous Huxley wrote to his brother, Julian: "We performed a superb play invented by Katherine, improvising as we went along. It was a huge success, with Murry as a Dostoevsky character and Lytton as an incredibly wicked old grandfather." 12 It would appear to be a case of having had to be there to appreciate how "marvellously witty" it was. The fragment that exists involves no less than two illegitimate children and the sudden return of the mother of one of them and is sketched in burlesque, faux drawing-room style. It is interesting that, when wishing to impress and entertain Bloomsbury, that intimidating combination of aristocrats, sprigs of Victorian academia, writers and thinkers, Mansfield chose to write a play.

Her chosen form, the short story, is defined by its brevity. Jenny McDonnell outlined its evolution:

The development of the modern short story form in Britain in the nineteenth century is perhaps best understood in relation to

10 To Ottoline Morrell, 24 April 1917, Letters, 1, 306.

11 Dora Carrington to Noel Carrington, 26 December 1916, Country Life, 23 December 1971, 1794.

12 Aldous Huxley to Julian Huxley, Grover Smith collection of Aldous Huxley correspondence, 1908-1985, MS 462, Woodson Research Center, Fondren Library, Rice University. 
changing publication practices...the exponential growth of the periodical press and the popular press throughout the nineteenth century contributed to the emergence of the short story form." 13

The short story was appropriated by experimental writers as part of the avantgarde characterised by The Yellow Book and their work spanned two axes, the popular and literary high art. The short story's brevity became a motivation for literary writers to alter their techniques, as Adrian Hunter pointed out:

[They developed] more artful and strategic economies, cutting away the kinds of material we normally depend upon for narrative continuity and coherence, for example, and working with these tactical omissions to suggest and imply meaning, rather than stating it directly. ${ }^{14}$

Hunter elaborates that this "literary" short story helped "to pave the way for its absorption into modernism in the early decades of the 20th century." ${ }^{15}$ It is this brevity that is of particular relevance to this thesis, which argues that Mansfield's use of performance-based techniques assisted her ability to rapidly convey character, theme and atmosphere in her stories. Quite how rapidly she works is what Anthony Alpers meant when he referred to her ability to capture character "at the speed of an electronic flash...on her high-speed film"16 and is illustrated by the opening paragraph of "Pictures" (1920):

Eight o'clock in the morning. Miss Ada Moss lay in a black iron bedstead, staring up at the ceiling. Her room, a Bloomsbury top-floor back, smelled of soot and face powder and the paper of fried potatoes she brought in for supper the night before. ${ }^{17}$

In three sentences we know Miss Moss isn't at work at eight in the morning and possibly isn't at work at all. Her staring at the ceiling may indicate low spirits. Her lodgings are impoverished and squalid and the mention of face

Jenny McDonnell, Introduction, Katherine Mansfield and the Modernist Marketplace (Hampshire: Palgrave Macmillan, 2010). Hereafter cited as McDonnell, Marketplace.

14 Adrian Hunter, The Cambridge Introduction to the Short Story in English (Cambridge: Cambridge University Press, 2007). Cited in McDonnell, Marketplace, 10.

15 McDonnell, Marketplace, 9.

16 Alpers, Life, 244.

17 KMCS, 119. 
powder hints at stage work. The main thrust of the story is sketched: an out-ofwork actress is poor and perplexed.

As a professional writer tailoring her work to a medium designed for timepressed commuters, she was acutely aware of the need for concision. In an unpublished letter, Wyndham Lewis called her the "lady mag writer." discipline imposed by the short story's brevity also spoke to her own, personal tastes and aesthetic sense. She wrote that she was as "fastidious as if I wrote with acid" and disliked the "sort of licence that English people give themselves - to spread over and flop and roll about." ${ }^{, 19}$ A stage or cinematic performance requires visual shorthand to establish both setting and character, conveyed by a set, a few props, with voice and tone being crucial in terms of character. There must be no superfluous actions or words to distract an audience. According to his brother, ${ }^{20}$ Chekhov's writing of his first play, Ivanov, resulted in a transformational moment to his own intellectual development and literary technique, expressed by a dramatic principle ("Chekhov's Gun") that requires every element in a narrative to be necessary and irreplaceable and everything else is superfluous:

Remove everything that has no relevance to the story. If you say in the first chapter that there is a rifle hanging on the wall, in the second or third chapter it absolutely must go off. If it's not going to be fired, it shouldn't be hanging there. ${ }^{21}$

Specific theatrical imagery (of an actual theatre) is frequently used by Mansfield. "Miss Brill" (1920) has been read closely by Delia da Sousa Correa $^{22}$ for its musical performativity and it is also rich in specific theatrical imagery:

Oh, how fascinating it was! How she enjoyed it! How she loved sitting here, watching it all! It was like a play. It was

18 Wyndham Lewis to Violet Schiff, c. 20 September 1922, British Library. Cited in Kathleen Jones, Katherine Mansfield The Story-Teller (North Shore: Penguin, 2010), 461. Also cited in Alpers, Life, 372.

19 To JMM, 19 May 1913, Letters, 1, 124.

20 From the biographical sketch, adapted from a memoir by Chekhov's brother Mikhail, which prefaces Constance Garnett's translation of Chekhov's letters, 1920.

21 Donald Rayfield, Anton Chekhov: A Life (New York: Henry Holt, 2000), 203.

22 Delia da Sousa Correa, "Performativity in Words: Musical Performance in Katherine Mansfield's Stories," Katherine Mansfield Studies 3 (2011): 21-34. 
exactly like a play. Who could believe the sky at the back wasn't painted? But it wasn't till a little brown dog trotted on solemn and then slowly trotted off, like a little 'theatre' dog, a little dog that had been drugged, that Miss Brill discovered what it was that made it so exciting. They were all on the stage. They weren't only the audience, not only looking on; they were acting. Even she had a part and came every Sunday. ${ }^{23}$

"Je ne Parle pas Français" (1918) uses similar imagery:

There does seem to be a moment when you realise that, quite by accident, you happen to have come onto the stage at exactly the moment you were expected. Everything is arranged for you - waiting for you. Ah, master of the situation! You fill with important breath. At the same time you smile, secretly, slyly, because Life seems to be granting you these entrances, seems indeed to be snatching them from you and making them impossible, keeping you in the wings until it is too late, in fact $^{24}$

Within these stories Mansfield's use of stage techniques can be grouped: the use of stage directions; dramatic dialogue; dramatic monologue; sound effects (onomatopoeia, voice, accents, music, song) and visual effects, including costume changes and costume props. This chapter will examine these one by one, using several stories to illustrate the technique. Mansfield's work uses music, voice and visual effects to create for the reader a sense of having seen and heard them as performances. That their immediacy and liveliness is due to these techniques is part of the central argument of this thesis.

Stage directions tell us when and where the action takes place and what the setting looks like. Their necessary brevity imposes upon a writer an economy and removes the need for further description. "At the Bay" (1921) has three simple words "Very early morning" to set the scene of one day in the lives of the Burnell family and their community. ${ }^{25}$ The story "New Dresses" (1912) is in two parts, with the second starting: "A brilliant Sunday morning. Henry and Anne, quite reconciled, sitting in the dining room waiting for 
church time". 26 "The Lady's Maid" (1921) combines both a stage direction and sound effects, beginning:"Eleven o'clock. A knock at the door". ${ }^{27}$ "Late at Night" (1917), which began as an internal monologue for New Age and also appears as a short story, is the lengthiest example of stage direction:"Virginia is seated by the fire. Her outdoor things are thrown on a chair; her boots are faintly steaming in the fender" ${ }^{28}$ There are stories in which the stage direction appears in the middle of the story, such as "Pension Seguin" (1913):"Exit Helene, with her apron over her head". ${ }^{29}$ As mentioned earlier, "Pictures" (1920) begins:"Eight o'clock in the morning. Miss Ada Moss lay in a black iron bedstead, staring at the ceiling". As a final example, in "Je ne Parle pas Français," Mansfield writes:

(Soft music. Mouse gets up, walks the stage for a moment or so before she returns to her chair and pours him out, oh, such a brimming, such a burning cup...) $)^{30}$

The paragraph starts with a stage sound direction and then goes onto explicitly refer to the space they are in (the hotel which the narrator, Raoul Duquette, has arranged) as "the stage." A recurring motif in the story is that of Duquette casting himself and other characters as performers and alluding to their performances, which has the effect of creating a distance between the reader, the characters and the narrator.

Dialogue is obviously a widely used writerly device. What follows is an analysis of Mansfield's dramatic sketches which are dialogue-only and form a part of her early apprenticeship as a writer. Her use of other stagecraft sets her apart from other writers who use dialogue or monologue but do not employ the range of techniques she did. A glance at almost any page of a Mansfield story demonstrates the dominance of dialogue and the use (arguably, overuse) of exclamation marks, which give the work a declamatory appearance. Elizabeth Bowen, writing of Mansfield in 1956, stated:

KMCS, 543.

KMCS, 375.

KMCS, 637.

KMCS, 582

KMCS, 85. 
Words had but one appeal for her, that of speakingness. (In her journal we find, noted, "The panting of a saw.") She was to evolve from noun, verb, adjective, a marvellous sensory notation hitherto undreamed of outside poetry; nonetheless she stayed subject to prose discipline. ${ }^{31}$

Mansfield's first published work in England, "The Child Who was Tired," appeared in the New Age on 4 February, 1910. This weekly periodical was a significant force in the early 20th century, publishing writers such as Shaw, Chekhov, Bennett, Arnold and others. This was followed by "Germans at Meat" on 3 March and, a little later, by other Bavarian sketches. It was not until June the following year that a work using dramatic dialogue was published, "The Festival of the Coronation (with apologies to Theocritus)." It is this work, and the subsequent publication of more dramatic sketches, that form the segment of the Mansfield canon that is unequivocally dramatic in execution. Later stories that will be examined in this chapter also use dramatic dialogue augmented with other stage techniques, but, as Elizabeth Bowen observed in the quotation above, they are works "subject to prose discipline" and are not in the overtly theatrical format of the New Age sketches.

The subtitle of "The Festival of the Coronation," "with apologies to Theocritus" is significant, as T.O. Beachcroft has written:

For centuries before the days of print, the short story was dominated by the presence of the story teller. The living narrator was essential: he could moralise, explain, cover years in a moment...However, throughout the long development of the short story there existed in the XVth Idyll of Theocritus an almost perfect model of the short realistic short story that is intended for reading and reveals itself without a personal narrator. $^{32}$

Mansfield's knowledge of Theocritus would have given her an example of a narrative without narrator, which allows a writer to let characters, literally, speak for themselves and reveal their personalities through that speech. "The Festival of the Coronation" features two main characters, Gwennie and Tilly. They have planned to go into central London to see the procession of the

31 Elizabeth Bowen, "A Living Writer," ed. Pilditch, Critical Response, 73.

32 T.O. Beachcroft, "Katherine Mansfield's Encounter with Theocritus," ed. Pilditch, Critical Response, 120. 
coronation of King George V and their dialogue is a combination of somewhat facile, gossipy interchange and more significant communication. To illustrate the former, a hat is the subject:

Gwennie: Pop on your things and let's start. I read in the Daily Mail the procession will be wonderful.

Tilly: In the Daily Mail everything is wonderful. Do you think I dare risk my best hat?

Gwennie: Doubtful. I've come out in rags. Trimmed this hat before I got into bed last night. The red velvet's off a cushion cover, my dear, and I picked up the cornflowers for $23 / 4 \mathrm{~d}$ a bunch years and years ago.

And after this, a theme Mansfield explored in her work, the nature of relationships between women:

Tilly: It's raining again. I'll tell you an unromantic fact. I've got a corn on my little toe, and this weather simply makes it shoot ... Isn't it a comfort to be with a woman and feel able to say those things? I'd just as soon go about with a woman as a man.

The essence of the method is an adaptation of the scriptwriting maxim: "Show, don't tell" into "Say, don't describe or explain." It was 18 months later that the New Age published: "Stay-Laces" (4 November, 1915) and another 18 months after that before a slew of Mansfield's dramatic efforts were published: "Two Tuppeny Ones, Please" (3 May, 1917); "Late at Night" (10 May, 1917); “The Black Cap" (17 May, 1917); “In Confidence” (24 May, 1917); “The Common Round" (31 May, 1917); and "A Pic-Nic" (7 June, 1917). Several of the dramatic works were subsequently published as short stories: "Late at Night"; Two Tuppeny Ones, Please"; and "The Black Cap," keeping in the stage directions. "The Common Round" was re-worked as the story "Pictures." What this illustrates, above all else, is the ease with which Mansfield could transform her dramatic dialogues into stories and the effect this aural orientation had on the construction of her writing that didn't start as a dramatic dialogue. Jenny McDonnell illustrated this with examples from "Pictures," the story about the out-of-work performer, Ada Moss. McDonnell commented: 
"Pictures" keeps this dialogue intact, presenting it in quotation marks as Miss Moss's direct speech, and also maintains stage directions, incorporating them into the text as a form of exposition...in recasting the dialogue into a prose form, Mansfield has successfully "combine[d] the animation of the mime with a story intended for reading", a fusion of dramatic and narrative techniques that Beachcroft argues is central to her mature writing. ${ }^{33}$

An example of Mansfield's use of dialogue in a later story is the rather fey "An Ideal Family" (1921). After setting the scene, the story is, essentially, dialogue:

"The food altogether was too appalling," came from Marion. "Still, it's rather early for ices," said Charlotte easily.

"But why, if one has them at all ..." began Ethel.

"Oh, quite so, darling," crooned Charlotte.

Suddenly the music-room door opened and Lola dashed out. She started, nearly screamed, at the sight of old Mr Neave.

"Gracious, father! What a fright you gave me! Have you just come home? Why isn't Charles here to help you off with your coat?"34

This passage, like many in Mansfield's work, can be seen as a small dramatic vignette within the larger story, employing dialogue which is enhanced by the description of the sounds of the voices: "easily"; "crooned"; "screamed," and which serve as stage directions to the reader's understanding of the scene in lieu of an actor's performance.

33 McDonnell, Marketplace, 96.

KMCS, 371. 
The dramatic monologues Mansfield wrote include: "Stay-Laces" (1915); “Two Tuppenny Ones, Please" (1917); and "Late at Night” (1917).

A story, "The Lady's Maid" (1920) is also a dramatic monologue. In it Ellen, the maid, tells the story of her life and thwarted ambitions. As mentioned earlier, it is one of the stories Mansfield wrote in a letter she would have liked to perform herself: "I intend next Spring to go to London, take the Bechstein Hall and give readings of my stories" ${ }^{35}$ Ellen's story is one of abuse and self-abasement. She recounts cutting off her hair as a child and her hairdresser grandfather shutting her fingers in hot hair tongs for punishment, "It was a fearful burn. I've got the mark of it today." ${ }^{36}$ She goes on to recount going into service aged 13, "not so very" young, and into a relationship with a manipulative mistress that leads her to deny herself the opportunity of love and independence. Unlike most Mansfield stories, “The Lady's Maid” doesn't use stage techniques to animate it because it is itself a one-person vocal performance. The effects used are the narrator's vignettes, which are sharply visual: her mistress's mother "laid out" with a bunch of pansies; herself as a child hiding under a table in her grandfather's hairdressing shop, playing with dolls; her grandfather burning her with the tongs; her running outside "with my hand rolled in my pinny and my hair sticking out"; the seaside donkeys she craved to have a ride on and finally, rejecting her male friend and running outside "in my apron and my house shoes." 37 The phrase: "People must have laughed if they saw me," used after the similar childhood incident, is repeated.

A technique Mansfield employs is one Colette used in her literary mimes, that of an interlocutor as a silent voice, which renders the writing a monologue. An example is Mrs Bone in "Stay-Laces," where an ellipsis is employed to convey the silence:

Sweet Thing: Corsets, madam?

Mrs Busk: Yes. I want to see some corsets that fasten down the front.

Mrs Bone: ...!

To Ida Baker, 30 April 1922, Letters, 5, 160.

KMCS, 377.

KMCS, 377. 
Mansfield's dramatic monologues are interesting as experiments in literary technique, but they are not numerous. They do, however, illustrate her working in a specifically performative format.

The intensely auditory quality in many, if not most, of Mansfield's stories is remarkable. Her use of sound effects can be divided into three main categories: the use of onomatopoeia, voice and accents, song and music. In a dramatic production, sounds and music can motivate actions onstage and indicate events taking place offstage; establish the time of day, season and weather; locate the action in a specific place; create mood and changes in mood; stimulate audience expectations of what is to come; provide information about the characters and build transitions between scenes and offer shortcuts that rapidly advance the plot or recall past events.

“Ole Underwood" (1913) is a vivid and early example of Mansfield's use of sound effects, employing mainly onomatopoeia. Its staccato tempo emphasises its auditory quality. Its main character, Ole Underwood, barely speaks, yet the story a cacophony of noise, raucous with sound effects and, ironically, the effect of sound. This tough, uncompromising story literally screams into life:

The pine trees roared like waves in their topmost branches, their stems creaked like the timber of ships..."Ah-k! shouted Ole Underwood..."Ah-k!" shouted the wind a hundred times as loud. ${ }^{38}$

The noisy, abrasive wind is linked with Ole Underwood throughout the story. Sound and a lack of sound define Ole Underwood:

Something inside Ole Underwood's breast beat like a hammer. One, two - one, two - never stopping, never changing. He couldn't do anything. It wasn't loud. No, it didn't make a noise - only a thud. One, two - one, two - like someone beating on an iron in a prison, someone in a secret place - bang - bang bang - bang - trying to get free. Do what he could...he couldn't stop the noise. Stop! Stop! Stop! Stop! ${ }^{39}$

\footnotetext{
$38 \quad$ KMCS, 562.

39 Ibid.
} 
Ole Underwood's heart is broken and it, too, is noiseless: “it didn't make a noise - only a thud" but it keeps beating, all the same, relentlessly driving him onwards. He is a terrifying sight to children:

When she saw Ole Underwood she let the clothes prop fall and rushed to the door, beating it screaming "Mumma! Mumma!" That started the hammer in Ole Underwood's heart. ${ }^{40}$

The screaming reels him back to his own mother witnessing him being taken to prison: "he pulled a face as if he wanted to cry." wordless letting go of emotion. Going into a pub for a drink is just as fraught: "A great jar of red pinks stood on the bar counter. Ole Underwood stared at them as he drank and frowned at them. Red-red-red-red! Beat the hammer.",42 He crushes the red (colour of blood and life) flowers and is loudly rebuked: "Uh-Uh! You ole beast! Uh! You ole swine!" screamed the girl, leaning across the counter and banging him with a tin jug. 'Get art! Get art! Don' you never come 'ere no more!" ${ }^{43}$ Ole Underwood walks through the Chinese quarter and, opening a door, disturbs a group of men: "In rushed the wind with him, scattering the cards." The Chinese also can't speak his language but make themselves clear: "'Ya-Ya! Ya-Ya!' screamed the Chinamen, and Ole Underwood rushed off, the hammer beating quick and hard." 44 A little grey cat comes up to him:

The hammer in Ole Underwood's heart beat madly. It pounded up into his throat, and then it seemed to half stop and beat very, very faintly. "Kit! Kit! Kit!" That was what she [the wife he killed for having an affair with another man] used to call the little cat he brought her off the ship - "Kit! Kit! Kit!",5

The only words Ole Underwood utters are "I will! I will! I will!" before he hurls the kitten into a sewer opening. After this: "The hammer beat loud and strong. He tossed his head, he was young again." 46

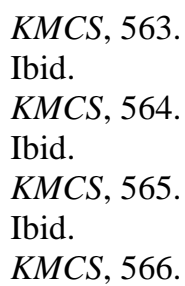


Ole Underwood has no voice, which is unusual in a Mansfield story. Voices and their tone are an essential part of characterisation in most of her stories, which is made all the more significant if we understand the stories are to be read aloud, as she herself did when writing Miss Brill: "I chose not only the length of every sentence, but even the sound of every sentence...I read it aloud...just as one would play over a musical composition." ${ }^{47}$ Ida Baker described the sound of Mansfield's voice: "There was a bell-like quality in her low rich voice ${ }^{, 48}$ and she clearly believed in her own vocal capacity to hold an audience, expressing in her letter to Garnet Trowell ${ }^{49}$ her desire to appear on stage, using only voice to convey stories and impressions:

to study tone effects in the voice - never rely on gesture though gesture is another art and should be linked irrevocably with it - and express in the voice and face and atmosphere all that you say. Tone should be my secret, each word a variety of tone... ${ }^{50}$

In "A Truthful Adventure" (1911) Mansfield references the role of voice and performance:

I coughed and cleared my throat in that unpleasant and obtrusive way of strange people in next-door bedrooms. It acted like a charm, their conversation sifted into a whisper for female voice only! $!^{51}$

Her composition is of words, but it is voice that makes words musical and conveys character. Mansfield also uses voice to emphasise a theme, such as the tacit solidarity of women. In "At the Bay" (1921) the departure of Stanley Burnell elicits a vocal response from the women:

Oh, the relief, the difference it made to have the man out of the house. Their very voices were changed as they called to one another; they sounded warm and loving and as if they shared a secret. $^{52}$

To Richard Middleton Murry, 12 August 1918, Letters, 4, 165

LM, Memories, 233.

To Garnet Trowell, 2 November 1908, Letters, 1, 84.

To Garnet Trowell, 2 November 1908, Letters, 1, 84.

KMCS, 532.

KMCS, 213. 
Another example is "Prelude" (1917) where the tone of Linda Burnell's and Mrs Fairfield's voices conveys both intimacy and isolation:

and she spoke to her mother with the special voice that women use at night to each other as though they spoke in their sleep or from some deep hollow cave. ${ }^{53}$

Equally, in "Prelude" there is another female to female exchange, but one in which voice is not an instrument of empathy but, from the servant Alice's point of view, one of class control:

She wasn't one to mind being told, but there was something in the way Miss Beryl had of speaking to her that she couldn't stand. Oh, that she couldn't. It made her curl up inside as you might say, and she fair trembled. But what Alice really hated Miss Beryl for was that she made her feel low. She talked to Alice in a special voice as though she wasn't quite all there. ${ }^{54}$

Voice is often an instrument of desire for Mansfield. The male character in "A Dill Pickle" (1917) says:

"another thing about you that hasn't changed at all - your beautiful voice - your beautiful way of speaking... you have only to say one word and I would know your voice among all other voices. I don't know what it is - I've often wondered what makes your voice such a - haunting memory..."55

In "Late at Night" (1917) one of the New Age dramatic monologues, the female protagonist says: "He has a most fascinating voice. I think it was his voice that attracted me to him."56 "Carnation" (1918) is an explicitly sexual story, with arousal by sound (onomatopoeia) and voice at its centre. It is partly drawn from Mansfield's experiences as a student at Queen's College. In Notebook 45, she wrote:

And why didn't I learn French with M. Huguenot? What an opportunity missed! He lectured in a long narrow room that was painted all over... Below the windows, far below, there was a stable court paved in cobblestones - one could hear the faint clatter of carriages coming out or in, the noise of water 
gushing out of a pump into a big pail, some youth clumping about and whistling. ${ }^{57}$

The story revolves around two female students in a French class taken by M. Hugo. Eve is the more flamboyant of the two, bringing flowers to class and describing them as "simply divine" or asking "Isn't it a darling?" Katie is wary of Eve: "But how cruel her little thin laugh was! It had a long sharp beak and claws and two bead eyes, thought fanciful Katie" and doesn't know enough French to understand M. Hugo, unlike Eve. Eve's omnivorous sexual appetite is described in the opening paragraph, with a literal description of deflowering:

On those hot days Eve - curious Eve - always carried a flower. She snuffed it and snuffed it, twirled it in her fingers, laid it against her cheek, held it to her lips, tickled Katie's neck with it, and ended, finally, by pulling it to pieces and eating it, petal by petal. ${ }^{58}$

The rest of the class is completely impervious to the sexualised atmosphere in the classroom, "dead at the first shot" 59 as M. Hugo begins to recite French poetry. Katie, (a name by which Mansfield herself was known, amongst many others) not being able to understand the French language, is experiencing it only as sound:

He would begin, softly and calmly, and then gradually his voice would swell and vibrate and gather itself together, then it would be pleading and imploring and entreating, and then rising, rising, triumphant until it burst into light, as it were and then-gradually again, it ebbed, it grew soft and warm and calm and died down into nothingness.

In the above passage M. Hugo's voice is described in terms of male arousal: "rising, rising" to a climax followed by the organ becoming "soft and warm and calm and died down into nothingness." ${ }^{\circ 0}$ Katie listens to M. Hugo as described above, but also to what is going outside the classroom, which is, for her, equally provocative and also caused by sound: "Now she could hear a man clatter over the cobbles and the jing-jang of the pails he carries. And now Hoo-

Notebooks, 2, 31

KMCS, 653.

KMCS, 655.

KMCS, 655 . 
hor-her! Hoo-hor-her! as he worked the pump."61 The sound and noise reaches a climax, with the image of a male orgasm, "a great gush of water followed."62 Sound effects continue with "all the while he worked the man kept up a high, bold whistling that skimmed over the noise of the water as a bird skims over the sea." ${ }^{\prime 63}$ The working man outside is described in terms of virile, masculine attractiveness:

She saw him simply - in a faded shirt, his sleeves rolled up, his chest bare, all splashed with water - and as he whistled, loud and free...Hugo-Wugo's voice began to warm, to deepen, to gather together, to swing, to rise - somehow or other to keep time with the man outside (Oh, the scent of Eve's carnation!) until they became one great rushing, rising, triumphant thing, bursting into light, and then - The whole room broke into pieces. $^{64}$

Katie's climax is caused by the combination of sounds from inside the room (M. Hugo's voice, speaking a language she doesn't understand) and outside (the sounds of the man working: the clatter on the cobbles, the jingle of his pail, the gushing water, his whistling). None of this is related to words and their meaning, but rather to sounds and their effects. Most of the class do not respond, certainly not in the way Katie does. But they understand enough not to enjoy it:

The great difficulty was, of course, if you felt at all feeble, not to get the most awful fit of the giggles. Not because it was funny, really, but because it made you feel uncomfortable, queer, silly, and somehow ashamed for old Hugo-Wugo. ${ }^{65}$

But for Katie, the sight of the half-naked working man, pumping and whistling, combined with the teacher's voice, results in a sexual experience provoked by voice, sound (whistling) and noise. The onomatopoeic Hoo-horher! Hoo-hor-her! can also be read as a pun: Who-whore-her! Who-whore-her! The story ends suggestively, with Eve flirting with Katie: "'Souvenir tendre,' [she said] and she popped the carnation down the front of Katie's blouse." Eve

Ibid.

Ibid.

KMCS, 656.

Ibid.

KMCS, 655 
is sexually knowledgeable from the beginning of the story, and Katie becomes sexually aware during it. The implication of the ending is that Eve realises this and will take advantage of it, as Katie's climax "to swing, to rise - somehow or other to keep time with the man outside" is combined with "Oh, the scent of Eve's carnation!" ${ }^{66}$ The story works as an illustration of Mansfield's earlier expression of wanting to explore "the whole octave" of sex, with M. Hugo's recital of French poetry standing in for the aesthetic, literary life; the workman representing a life more warm, free and physically sensual; and Eve there also, the original woman with her own knowledge of desire.

For Mansfield, "the born actress and mimic,"67 accents were a means by which to inject humour and character by means of sound into her work. As a New Zealander in London, Mansfield's own accent may have been subject to mimicry, as Angela Smith pointed out: "[Rupert] Brooke [...] may have been mocking Mansfield's accent when he writes 'lidy." "68 Equally, Brooke could have been referencing Mansfield's own frequent use of a cockney accent. Mansfield used accents to give character and comedic value. The most famous is Mrs Samuel Joseph's asthmatic wheeze in "Prelude" (1917) which can also be read as a form of stage Yiddish, the "Samuel Josephs" being based on the Beauchamps' Jewish friends, the Nathans:

Why nod leave the chudren with be for the afterdoon Brs Burnell? They could go on the dray with the storeban when he comes in the eveding. ${ }^{69}$

She mimics American accents in "The Man Without a Temperament" (1920)

And she knoo it was there - she knoo it was looking up at her just that way. ${ }^{70}$

And uses the same word effect in "The Dove's Nest"(1921): [he had] a strong American accent..."I should very much like to renoo our - well - I venture to

KMCS, 656.

LM, Memories, 233.

68 Angela Smith, Katherine Mansfield: A Literary Life (Basingstoke, New York: 2000), 2. Hereafter cited as Smith, A Literary Life.

KMCS, 12.

KMCS, 129. 
hope we might call it a friendship."71 But also mittel European, as in "Father and the Girls": "I can let you ave very naice rooms on de firs floor wid a lif. Two rooms and bart and dressing-room for de chentleman. Beautiful rooms wid sun but nort too hot.,"72 Or "The Little Governess" (1915):“'Ow-do-you-do. Please vich is ze vay to Leicestaire Squaare?" ${ }^{, 73}$ Mansfield skewers not only accent by nationality but also pretentious, British ones. In "The Daughters of the Late Colonel" (1920) an achingly pretentious tone is rendered:

"When I was with Lady Tukes," said Nurse Andrews, "she had such a dainty little contrayvance for the buttah. It was a silvah Cupid balanced on the-on the bordah of a glass dish, holding a tayny fork." $" 74$

Mansfield's use of accents enhances the sense of "speakingness" of her words which Elizabeth Bowen referred to and which is quoted earlier in this chapter under Dramatic Dialogues.

Mansfield's proficiency as a musician was demonstrably of a high standard (as illustrated in Chapters One and Two) and there is evidence in her letters and stories that it was important to her. Music is a motif running throughout her work, even in a description of seeking a place to stay in "Pension Seguin" (1913):

At the start I flew up innumerable stairs as though they were major scales - the most cheerful things in the world - but after repeated failures the scales had resolved into the minor. ${ }^{75}$

The image of scales, which are an octave-based means of practising fingering and which are played up and down repeatedly, is well suited to the ascent and descent of a staircase. Song and music are both musical effects threaded throughout many stories. Obviously music can be described but not "heard" in a story, whereas words can be juxtaposed against a narrative, in the same way a composer uses counterpoint. In music: "Counterpoint is the relationship between voices that are harmonically interdependent (polyphony) yet 
independent in rhythm and contour." ${ }^{, 76}$ Specifically song-oriented stories are "Mr Reginald Peacock's Day" (1917) and "The Singing Lesson"(1920) in which both singing and the teaching of singing are the basis of the stories. Another story, "Honeymoon"(1922) which explores the effect of song without the author using any lyrics, will be used later in this chapter to illustrate a less complex, but more purely musical idea of response to beauty.

Mansfield often has her characters burst into song: Beryl in "Prelude" (1917); the young men on the train in "The Little Governess" (1915); the old man in "Honeymoon"(1922); the servant girl in "The Man Without a Temperament"(1920) and the female character in the monologue "Late at Night"(1917) to name but a few. Singing is usually associated with the blitheness of youth and romance and the lyrics of their songs are usually ironic juxtapositions to a character's mood or situation. In "Prelude," Beryl sings two songs and Mansfield uses the lyrics of Beryl's songs to comment on both Beryl and Linda's stage of life and their resultant attitudes. She speaks to her sister of her sense of isolation in the new house:

"Oh, well at any rate it won't kill us," she said dryly ... "I am going to hang curtains." And she ran away singing:

"How many thousand birds I see

That sing aloud from every tree ..."

But when she reached the dining room she stopped singing, her face changed; it became gloomy and sullen. "One may as well rot here as anywhere else," she muttered savagely. ${ }^{77}$

The contrast of the blithe, flowery lyrics and Beryl's bitter sense of isolation is stark. Also stark is the contrast with her sister's earlier dream of a bird swelling in size and devouring her. Beryl's singing announces her to the servant girl, Alice: “'How many thousand birds I see.' Oh, life. There was Miss Beryl." ${ }^{, 78}$ And after telling Alice what to do: "Miss Beryl had finished. 'That sing aloud from every tree ...' she sang as she left the kitchen, very

76 Steven G. Laitz, The Complete Musician (New York: Oxford University Press, 2008), 96. Aldous Huxley's novel, Point Counter Point, in which Mansfield is satirised as Susan Burlap, uses this musical term as its overarching metaphor.

KMCS, 31.

KMCS, 48. 
pleased with her firm handling of Alice." ${ }^{, 79}$ Beryl's second song is part of her performance: "She played and sang half to herself, for she was watching herself playing and singing. The firelight gleamed on her shoes, on the ruddy belly of the guitar, and on her white fingers...

Nature has gone to her rest, love,

See, we are alone

Give me your hand to press, love

Lightly within my own. ${ }^{80}$

The next line is: "Even the moon is aweary ..." For Linda, in another room and fearful of pregnancy and childbirth, the moon isn't a romantic object. It represents the cycle of fertility which she dreads. For Beryl, love is holding hands and the moon can be weary.

Singing, and then not singing, is also used in "The Man Without a Temperament" (1920): "The servant girl was in their room, singing loudly... When she saw him her small, impudent eyes snapped and her singing changed to humming." 81 The suffocating nature of the servant-master relationship combined with the possible deadliness of the male protagonist of the story, suppresses the spontaneity and joyousness illustrated by song. In "Feuille d'Album" (1917) not singing is again significant: "She never sang or unbraided her hair, or held out her arms to the moon as young girls are supposed to do." 82 In "Honeymoon" (1922) Mansfield explores the effect of song without lyrics as a means of revealing character, in the way that "Carnation" used voice without an understanding of the words. "Honeymoon" is one of Mansfield's stories about a young couple and their fundamental misunderstanding of each other's emotional landscapes. George and Fanny are two young honeymooners and in the first paragraph Mansfield alerts the reader to George's possible insensitivity by means of his voice:

George stood on the pavement edge, lifted his stick, and gave a loud "Hi!" Fanny sometimes felt a little uncomfortable about 
the way George summoned cabs, but the drivers didn't seem to mind, so it must have been all right. ${ }^{83}$

They settle into a café: "It was in that heavenly moment that Fanny heard a twing-twing-tootle-tootle, and a light strumming. There was going to be music, she thought, but the music didn't matter just then. Nothing mattered except love." Instead of enjoying the moment, Fanny is prompted to be serious about the nature of their relationship: “'Do you feel,' she said softly, 'that you really know me now? But really, really know me?' George, in his amiable, foppish way replies: "I should jolly well think I do." ${ }^{84}$ Fanny, justifiably, "felt he hadn't quite understood" and persists:

"So often people, even when they love each other, don't seem to - to - it's so hard to say - know each other perfectly. They don't seem to want to. And I think that's awful. They misunderstand each other about the most important things of all." Fanny looked horrified. "George, we couldn't do that, could we? We never could." 85

Mansfield then goes on to describe exactly that happening. As in "Carnation," another language is employed, so the story's axis tilts on sound alone:

that quiet figure, which clasped its hands, and still with that faraway look, began to sing... Nothing was heard except a thin, faint voice, the memory of a voice singing something in Spanish. It wavered, beat on, touched the high notes, fell again, seemed to implore, to entreat, to beg for something, and then the tune changed, and it was resigned, it bowed down, it knew it was denied. ${ }^{86}$

George and Fanny have profoundly different responses to the plangent tones of the singer. For Fanny, it elicits an understanding of the paradox of beauty and suffering's coexistence:

Is life like this too? thought Fanny. There are people like this. There is suffering. And she looked at that gorgeous sea, lapping the land as though it loved it, and the sky, bright with 
the brightness before evening. Had she and George the right to be so happy? Wasn't it cruel? ${ }^{87}$

But George experiences it differently:

The old boy's voice was funny in a way, but, God, how it made you realise what a terrific thing it was to be at the beginning of everything, he and Fanny! George, too, gazed at the bright, breathing water, and his lips opened as if he could drink it. How fine it was! There was nothing like the sea for making a chap feel fit! ${ }^{88}$

The fatuous George's response ends the story: "The band began to play. 'Oh, God!' almost groaned George. 'Let's go before the old codger begins squawking again." ${ }^{89}$ Mansfield uses sound as the vehicle by which to portray the emotional truth of her characters. The depth of feeling conveyed by the singer leads Fanny to an oceanic experience of love and acceptance, whereas for George it is mere "squawking." George, a man who is casually arrogant in the way he summons a cab, is further tone deaf to his young wife's seeking of emotional understanding, and then to the profundity of the singer's message.

Katherine Mansfield was a dedicated follower of fashion. Much of her fascination lay in the ability of clothes to allow her to adopt another persona, attract attention and affect people's perceptions. Her visual and sensory appreciation of clothes (as well as a bisexual flirtiness, using clothes as a kind of Dance of the Seven Veils) is illustrated in a letter to Dorothy Brett:

I wonder if you will take your velour hat. It suits you marvellously. When I am rich you shall have velour hats by the dozing[sic] and a Persian lamb jacket made like your jazz velvet coat, lined with pale yellow brocade. A pinky pigeon grey very soft pleated skirt to go with it, crocodile shoes, thick grey silk stockings. And inside the coat a straight tunic of silver jersey de soie. I confess I am quite ravished away by you in the Persian lamb coat. I have just been with you to a concert - you wearing it. Everybody turned round; the orchestra stopped; the flute fainted and was carried out. A dark 
gentleman stepped forward and presented you with the Order of the Sun and Moon; it was the Shah of Persia. ${ }^{90}$

Her own appearance was important to her and often theatrical. Her brother-inlaw, Richard Middleton Murry, wrote that:

Katherine was a head-turner. The mode from Paris; the brown velvet jacket with silver buttons, the short skirt; the coloured stockings, the Spanish-Japanese hair-do, the high heels, the immaculate turnout. $^{91}$

Her friend Anne Estelle Rice provided the clearest illustration of quite how dramatically Mansfield presented herself:

Katherine appeared at the Closerie des Lilas on different nights in clothes so different they seemed almost disguises, now a hat covered in cherries, another time a cloak and a white fez, or a turban [On another occasion] only the yashmak was missing... she assumed the character of the costume she wore, dressing up was a very important part of Katherine Mansfield's imaginative nature. ${ }^{92}$

Angela Smith has interpreted the costume changes as an indication of Mansfield's personal exploration of social boundaries:

Implicit in these disguises, Maori, Japanese or cross-dressing, is an awareness of multiple selves, and perhaps of the difficulty of deciding what aspect of the 'soul' to reflect in one's clothes, since the changes of costume indicate ambivalence about race, gender and social position. ${ }^{93}$

Evidently clothes also mattered to John Middleton Murry. In a letter to Anne Drey ${ }^{94}$ Mansfield used the form of dialogue to describe it:

[He just had a new suit made $\&$ is standing in front of me]

J.M: "Are the trousers full enough?"

K.M: "Quite full enough!"

J.M: "You're sure?"

K.M: "Certain!"

90

91

\section{Biography, 61.}

92 Rice, "Memories of KM", 87.

93 Smith, A Literary Life, 47.

94 To Anne Drey, 28 August 1922, Letters, 5, 259. 
J.M: "They're not too full?"

K.M: "Not in the least!"

J.M: "You're sure?"

K.M: "Certain!"

I must run and get a Bible and swear on it. "Those trousers are PERFECT!!!”

Their shared enjoyment and appreciation of costume is equally well conveyed in a letter that Mansfield wrote to Richard Middleton Murry:

I wish you could see him. He wears a blue helmet, you know the kind - airman's helmet, a leather jacket, huge fingerless gloves...breeks, three pairs of stockings and ski boots. He would earn enormous sums on the pictures in this get up \& all covered in snow. I can hear a deep 'A-Ah' go round the dark theatre as he leapt on to the screen. ${ }^{95}$

For Mansfield, clothes held a magical capacity to transform in life in the same way they transform characters on stage. In a letter to her Russian friend, Koteliansky, she wrote:

Last night I wore my dress. You cannot think how much I liked it. It is very lovely and there is something almost fairy in it. It makes me feel that wonderful adventures might happen if only one is dressed and ready. ${ }^{96}$

The above extracts and anecdotes all illustrate Mansfield's personal penchant for using clothing in a performative sense, to disguise, pique interest, or underline difference in an oblique and ironic way. It can also be viewed as a development of the earlier influence of Oscar Wilde on her outlook, as Clare Hanson and Andrew Gurr remarked: "The Symbolist belief in the artist's ability to create himself, to become his mask, sustained her throughout her career." 97

The purpose of stage costumes is to provide audiences with information about character, such as occupation, social status, gender, age, sense of style and tendencies towards conformity or individualism. Costumes can also reinforce the mood and style of the production; distinguish between major and

95 To Richard Middleton Murry, 2 January 1922, Letters, 5, 4.

96 To S.S. Koteliansky, 26 February 1915, Letters, 1, 151.

97 Clare Hanson and Andrew Gurr, Katherine Mansfield (London: Macmillan, 1981), 11. 
minor characters; suggest relationships between characters; change an actor's appearance; suggest changes in character development and age and be objects of beauty in their own right. The eminent stage designer Robert Edmond Jones summarised the main factors in costume design:

A stage costume is the creation of the theatre. Its quality is purely theatrical and, taken outside of the theatre, it loses its magic at once...Each separate costume we create for a play must be exactly suited both to the character it helps to express and to the occasion it graces. ${ }^{98}$

The power of props is illustrated by Charlie Chaplin, a performer Mansfield admired: "have just seen Charlie in The Kid...He is a marvellous artist." 99 As sound was not widely used in cinema until the mid to late 1920s, Mansfield's experience of film was of silent productions, essentially mimes, which made the use of costume and props more important. Chaplin's character, the tramp, is instantly recognisable by his bowler hat, umbrella and moustache. Later in this chapter, Mansfield's use of hats and umbrellas will be looked at more closely. Costume design includes accessories such as canes, hats, gloves, shoes, jewellery or masks. Such costume props add a great deal of visual interest to the overall costume design and are often the items that truly distinguish one character from another. An example of what can be conveyed by costume is Mansfield's description of the young Edna in "Taking the Veil" (1922):

It is not easy to look tragic at eighteen, when you are extremely pretty...Above all, when you are wearing a French blue frock and your new spring hat trimmed with cornflowers. ${ }^{100}$

A reader immediately understands much about Edna: her frock is "French," suggesting sophistication and also the means to buy expensive, imported garments. Her hat is new for the season and by being trimmed with [blue] cornflowers, conveys a maidenly simplicity and naivety. A parasol is also treated as a symbol of spring and is described in the same way that asparagus

98 Cited in Trevor R. Griffiths, Stagecraft (London: Phaidon Press, 1982), 109. Hereafter cited as Griffiths, Stagecraft.

99 To Richard Middleton Murry, c.20 August 1922, Letters, 5, 250.

100 KMCS, 407. 
or strawberries are often referenced. The image of a peach to describe colour echoes the similarity: "Now she actually saw in the distance a parasol, peachcoloured, the first parasol of the year."101 Philip Keel Geheber has offered an interpretation illustrative of Mansfield's complex and performative use of costume in "An Indiscreet Journey," which centres on the main character wearing a Burberry coat. Geheber posited that Mansfield deploys the Burberry as camouflage and disguise as she moves through a war zone:

Mansfield's female character needs an article of clothing that would conceal her body to prevent recognition. She thinks the Burberry is "the sign and the token of the undisputed venerable traveller" and the aside ascribes romantic, adventurous qualities to the coat: "Lions have been faced in Burberry, ladies have been rescued from open boats in mountainous seas wrapped in nothing else." 102

A Burberry is also unisexual, in that both men and women wear essentially the same design.

Mansfield makes costume perform many functions in her stories. In some, costume itself is a complex, multi-layered performance which conveys much about character, such as "Je ne Parle pas Français," in which Duquette describes himself:

I wore a blue kimono embroidered with white birds and my hair was still wet; it lay on my forehead, wet and gleaming. "Portrait of Madame Butterfly," said I, "on hearing of the arrival of ce cher Pinkerton. "103

A kimono is traditionally a garment worn by Japanese women, and in comparing his image with that of Madame Butterfly, the ostensibly male (his first name is Raoul) Duquette is identifying not only with a famous, operatic, female victim of male callousness, but also with performance itself. He is performing the role of a female performer. Mansfield's profound appreciation

\footnotetext{
101 Ibid.

102 Philip Keel Geheber, "Nous ne suivons pas la même route': Flaubertian Objectivity and Mansfield's Representations of Travel," Katherine Mansfield and Translation, eds. Claire Davison, Gerri Kimber, Todd Martin (Edinburgh: Edinburgh University Press, 2015), 9697. KMCS, 74.
} 
of the ability of costume to alter perception is also expressed by Raoul Duquette:

He was looking the part, he was the part.

How can one look the part and not be the part? Or be the part and not look it? Isn't looking - being? Or being - looking? ${ }^{104}$

"Je ne Parle pas Français" is one of Mansfield's most highly-geared and consciously performative works. Raoul Duquette is aware of himself as an actor and casts others around him in performative terms. Mansfield uses both cinematic and stage imagery in a complex matrix to characterise him and her own response to performance and mass culture. She makes particular use of costume, with Duquette exploring it for its appearance and its ability to confer identity:

"Since you left Paris", said I, knotting my black silver-spotted tie in the (also unpaid for) mirror over the mantelpiece...I cried, seizing the clothes-brush and brushing the velvet collar of my new indigo-blue overcoat...It was impossible not to believe this of the person who surveyed himself finally, from top to toe, drawing on his soft grey gloves. ${ }^{105}$

Clothes are important to Duquette, and he describes an expensive collection of clothing items, conveying an appetite for and acquisition of luxury goods, which is in stark contrast to his evident penury: "I have quantities of good clothes, silk underwear, two evening suits, four pairs of patent leather boots with light uppers, all sorts of little things, like gloves"106 The key female character, Mouse, is also defined by her clothing and, in particular, clothing props. Mouse is characterised in the story by her muff, beginning with Duquette's first sight of her: "At that moment she caught sight of him and hailed him with her minute muff."107 Not long after: "She bent her head and began stroking her grey muff; she walked beside us stroking her grey muff all 
the way." The section of the story ends with: "And Mouse got in the black hole and sat stroking Mouse II [the muff] and not saying a word."108

"Muff" is a vulgar term for a woman's genitals, with its origins in the 17th century. ${ }^{109}$ Mansfield uses this costume prop to intensify the gender identification in this story. It is Mouse's gender which most threatens Duquette and his adoration of "Dick" Harmon. He may be "plump, almost like a girl, with smooth shoulders," but Dick is involved with a real girl, and Mansfield uses a costume prop as a visual aid to underscore the gender difference, as well as conveying timidity and victimhood. Another meaning of "muff" is to make a blunder, a stupid mistake. Dick Harmon is the Englishman who deceives both his former boyfriend, Raoul Duquette, and his girlfriend, "Mouse." "Dick" is a term for a man's penis that has its origins in the 18th century ${ }^{110}$ and can also mean "a stupid or contemptible man."

Costume and costume props as signifiers of national identity are explicitly referenced in the next section of the story, this time with Duquette implying Mouse as a self-aware wardrobe mistress of herself:

She wore a long dark cloak as one sees in old-fashioned pictures of Englishwomen abroad. Where her arms came out of it there was grey fur - fur round her neck, too, and her closefitting cap was furry. "Carrying out the mouse idea," I decided. $^{11}$

Duquette orders a whisky, even though he doesn't like it, because he was "going to write about an Englishman." He then conflates national stereotypes with clothing:

We French are incredibly old-fashioned and out-of-date still in some ways. I wonder I didn't ask him at the same time for a pair of tweed knickerbockers, a pipe, some long teeth and a set of ginger whiskers. ${ }^{112}$

\footnotetext{
108 KMCS, 79.

109 www.dictionary.com/browse/muff Accessed July 18, 2017.

110 www.oxforddictionaries.com/ Accessed July 18, 2016.

111 KMCS, 81.

112 KMCS, 82.
} 
"Je ne Parle pas Français" ends with fantastical costume changes:

I begin to dream things like...A little house on the edge of the sea, somewhere far, far away. A girl outside in a frock rather like Red Indian women wear...The same girl, the same boy, different costumes - sitting at an open window, eating fruit and leaning out and laughing. ${ }^{113}$

The phrase "A little house on the edge of the sea" sounds like the Beauchamp family seaside home in Wellington's Days Bay, and “a frock rather like Red Indian women wear" could be read as an allusion to the fringe qualities in Maori clothing. Mansfield ends these reveries with the ironic use of a prop and image she reiterated in other stories to convey togetherness and protectiveness, qualities Duquette has shown to be signally lacking: "A wet night. They are going home together under an umbrella. They stop on the door to press their wet cheeks together."114

In "The Little Governess" (1915) the young woman and the old man share an umbrella, but his umbrella protects her, traps her and conveys her pathetic gullibility. When she meets up with him, he appears: "beside her, more beautifully brushed than ever, with a rolled umbrella in one hand and yellow gloves instead of brown ones" And later:

when they came out of the picture gallery it was raining. The grandfather unfurled his umbrella and held it over the little governess. They started to walk to the restaurant for lunch. She, very close beside him so that he could have some of the umbrella too [and] he quite forgot to put down the umbrella even when the rain was long over ${ }^{115}$

Earlier in the story, we learn the little governess has her own: "when the boat stopped and she went up on deck, her dress-basket in one hand, her rug and umbrella in the other"116 This will serve her as a means of protection and comfort: "Then the window was pricked with long needles of rain...but it did not matter...it was outside... and she had her umbrella" ${ }^{117}$ By sheltering under 
the old man's umbrella, the little governess is abandoning her own means of independence and protection and the prop performs a role as a visual metaphor of her neediness. The use of a parasol in "Taking the Veil" (1922) has already been mentioned and in "Mr and Mrs Dove" (1921) a parasol is again a key prop. A room in Colonel Procter's house is described: "the big room, shadowy, with someone's parasol lying on the top of the grand piano." 118 The parasol is "someone's," but Anne, the object of Reggie's unrequited affection, who finds him absurd and compares him to the male dove "bowing, bowing" after the female, laughs and runs away from him: [Anne] "walked away from him over to the piano, and leaned against it, playing with the tassel of the parasol."119 Anne's casual spite is characterised by her "playing" with the tassel of "someone's" parasol in the same way she plays with Reggie. Ole Underwood has a black umbrella, which "he flourished like a herald staff."120 A herald staff, or caduceus:

was often depicted being carried in the left hand of Mercury (or the Roman Hermes) the messenger of the gods, guide of the dead and protector of merchants, shepherds, gamblers, liars, and thieves. It is said the wand would wake the sleeping and send the awake to sleep. If applied to the dying, their death was gentle; if applied to the dead, they returned to life. ${ }^{121}$

Mansfield freights Ole Underwood's umbrella with a profound symbolic meaning, which casts him as messenger/guide of the dead and increases the deadly irony of the story's last two sentences:

A man lay sleeping on a bunk - his bunk - a great big man in a seaman's coat with a long, fair beard and hair on the red pillow. And looking down upon him from the wall there shone her picture - his woman's picture - smiling and smiling at the big sleeping man. ${ }^{122}$

\footnotetext{
118 KMCS, 288.

119 KMCS, 289

$120 \mathrm{KMCS}, 563$.

121 Spawforth Hornblower, Oxford Classical Dictionary, (Oxford: Oxford University Press, $3^{\text {rd }}$ ed., 1996), 690-91.

122 KMCS, 566.
} 
Possibly the most recurrent costume prop used by Mansfield is the hat. On stage: "No costume is complete without the right accessories...hats, shoes, gloves, sunglasses...can be used to suggest important aspects of character and help to create an effective overall design. ${ }^{123}$ In "Je ne Parle pas Français" the narrator, alludes ironically to the allure of the right hat:

I've no patience with people who can't let go of things ... The moment it leaves you it's changed ... Why, that's even true of the hat you chase after; and I don't mean superficially - I mean profoundly speaking ${ }^{124}$

Hats serve as social and class indicators (and objects of frivolous desire) in Mansfield's stories and reflect the prevailing social codes of her time. She uses them for comic effect in "The Dove's Nest" (1922):

Mother had half decided to wear her hat at lunch...

[Milly says]"Your mushroom or the jampot?"

"Oh, not the jampot, dear." Mother was quite used to Milly's name for it. "I somehow don't feel myself in a hat without a brim. And to tell the truth, I am still not quite sure whether I was wise in buying a jampot. I cannot help feeling that if I were to meet Father in it he would be a little too surprised."

Mansfield makes the comic effect run deeper than the obvious playfulness of describing hats as "mushrooms" or "jampots." Mother's comment about her late husband being surprised by her choice of hat underpins the dominant theme of women's lives being defined by male attention. Its significance as a motif can be seen in the following analysis, in which all the stories pivot on the social order being disrupted by wearing the wrong hat. It is most evident in "The Black Cap" (1917) one of Mansfield's dramatic dialogues published in the New Age. In it, a married woman is planning to leave her insensitive, businessman husband. She meets her lover at a train station.

Who is this? That's not him! It can't be - yes, it is. What on earth has he got on his head? A black cap. But how awful! He's utterly changed. What can he be wearing a black cap for?

123 Griffiths, Stagecraft, 120.

$124 K M C S, 65$.

$125 \quad K M C S, 448$. 
I wouldn't have known him. How absurd he looks coming towards me, smiling, in that appalling cap! ${ }^{126}$

Caps (and straw hats) are for the working classes. The man explains that he has lost his hat and borrowed the black cap from another man, but this doesn't assuage her reaction, which illustrates her almost religious adherence to appearances and social norms:

I mean if he looked at himself in the glass, and doesn't think that cap is too ridiculous, how different our points of view must be ... How deeply different! I mean if I had seen him on the street I would say I could not possibly love a man who wore a cap like that. I couldn't even have got to know him. He isn't my style at all. (She looks round.)

Everybody is smiling at it. Well, I don't wonder! The way it makes his ears stick out, and the way it makes him have no back to his head at all. ${ }^{127}$

Later, when they are arranging for a room at a hotel, Mansfield uses the cap to convey quite how extreme her reaction is and her need to separate from all it implies: "I must have my own room." (To herself.) "You can hang your cap behind your own door!" (She begins to laugh hysterically.) ${ }^{128}$ Demonstrating a recurring Mansfield theme, the lover completely misinterprets this: "Ah! Thank God! My queen is her happy self again!"129 When separate rooms do not materialise, she asks him to leave. (He looks round, distracted.)She: "What is it?"He: "My heart - you are sitting on my cap." (She gives a positive scream and moves into the bedroom. He goes. She waits a moment, and then puts down her veil, and takes up her suit-case. $)^{130}$ In this dialogue, Mansfield equates the man's heart with the cap, and by rejecting the cap, the woman is rejecting his heart, squashing it. The dialogue concludes with the woman leaving the hotel and returning to her husband.

"The Black Cap" is thematically close to one of Colette's stories, "Képi," in which an older female lover of a soldier puts on his army hat after making 
love. The combination of her age and the jaunty angle with which she wears it causes the younger man to see her as absurd and he leaves her. In "Six Years After” (1921) the wife says to her husband: “'It's your cap'... 'I can never get used to you in a cap. You look such a thorough burglar.",131 The giving of a hat and thereby conferring social status is also used in "The Daughters of the Late Colonel" (1920):

"Do you think Father would mind if we gave his top-hat to the porter?"

“The porter?” snapped Josephine ...

"Because," said Constantia slowly, he must often have to go to funerals...I noticed...he only had a bowler...I thought then how very much he'd appreciate a top-hat."

"In Confidence" (1917) was a dramatic sketch published in the New Age in May, 1917. A group of intellectual young men converse in a pretentious manner. The two women present, Marigold and Isobel, leave the room and the piece becomes a dramatic monologue, with Marigold speaking to Isobel, who remains silent. She suggests they have a walk:

Marigold: I'll run and put on a hat, and you must, too, darling. The sun is so strong, and you are not to get any more freckles on your nose, you bad child! The freckles that you have got are very charming - very sweet; but you can have too many, don't you think? And I never can see why one should look like a milkmaid simply because one lives in the country; can you?

(They separate. Marigold goes up to her room, powders her face...Pins on an immense straw hat that looks to have been pelted with its little bunches of cherries, and ties it under her chin with some wide tulle. Says to the person in the glass: 'Emma, Lady Hamilton,' and then bends her head forward and shoots out her under-lip a little, and murmurs: 'Mrs Siddons. ${ }^{133}$

The hat is the key to the ability to step into character, in this case the roles of two women connected by acting ability. Emma, Lady Hamilton was a famous

KMCS, 458

KMCS, 262.

"In Confidence", New Age, 24 May 1917, Katherine Mansfield - Dramatic Sketches, ed. David Drummond (Palmerston North: Nagare, 1988), 81. 
courtesan and the mistress of Horatio Nelson who was earlier known for what she called her "Attitudes," performances involving postures, dance and acting. It is the portraits of her by George Romney, always in a hat, that Mansfield is referring to in the above passage. Mrs Siddons, one of the most famous actors of all time, is remembered principally for her Lady Macbeth and her farewell performance of it, in which the audience refused to allow the play to continue after the sleepwalking scene.

Large black hats worn by women recur in several Mansfield stories and are a costume prop with a personal association. Ida Baker (again) recounts Mansfield spending an exorbitant sum on a large black hat to wear to greet her mother's arrival in London in 1909. According to Baker, Mrs Beauchamp initially ignored her daughter and then, noticing her, said: "Why, child! What are you wearing? You look like an old woman in that hat. As if you were going to a funeral." When they repaired to a hotel, Mrs Beauchamp instructed Mansfield to give the hat to the chamber-maid. "Then she went out and bought a charming fluffy tulle hat for Katherine."

In "The Garden Party" (1921) Laura's black hat is a motif which bears a narrative burden. Mrs Sheridan is trying on a new hat when Laura comes to tell her about the death of the carter's death. She gives it to Laura to distract her daughter from insisting the garden party be cancelled:

"Mother, isn't it really terribly heartless of us?" she asked.

"Darling!" Mrs Sheridan got up and came over to her, carrying the hat. Before Laura could stop her she had popped it on. "My child!" said her mother, "the hat is yours. It's made for you. It's much too young for me. I have never seen you look such a picture. Look at yourself!" And she held up her hand-mirror. ${ }^{135}$

Laura isn't able to look at herself in the mirror at that moment, but she goes into her own bedroom:

There, quite by chance, the first thing she saw was this charming girl in the mirror, in her black hat trimmed with gold

134 LM, Memories, 49.

KMCS, 255. 
daisies and a long black velvet ribbon. Never had she imagined she could look like that. ${ }^{136}$

Her brother, Laurie agrees: "My word, Laura! You do look stunning," said Laurie. "What an absolutely topping hat!"137 as do others at the garden party: "Darling Laura, how well you look!", 138 and "What a becoming hat, child!" ${ }^{139}$ When Laura agrees to take a basket of food from the garden party to the carter's family and begins to feel self-conscious about the hat: "How her frock shone! And the big hat with the velvet streamer - if only it were another hat! Were the people looking at her?"140 She tosses the velvet ribbon over her shoulder when she comes to the house. On seeing the dead young man, who ..."looks a picture"141 (the same words Laura's mother used to describe her in the hat) all Laura can say is "Forgive my hat." ${ }^{142}$ Laura, alone amongst her family, understands that the hat which was so charming and adult in the garden party setting is disastrously, frivolously inappropriate in the dead working man's cottage. Her recently acquired sophistication, courtesy of the hat, evaporates in the context of a real life experience. A black hat is again a significant costume prop in "The Tiredness of Rosabel" (1908). Rosabel works in a millinery store and an affluent young couple come in:

"What is it exactly that I want, Harry?" she had said, as Rosabel took the pins out of her hat, untied her veil, and gave her a hand-mirror.

"You must have a black hat," he had answered, "a black hat with a feather that goes right round it and then round your neck and ties in a bow under your chin, and the ends tuck into your belt - a decent-sized feather."143

KMCS, 256.

Ibid.

KMCS, 257

Ibid.

KMCS, 259.

KMCS, 261.

Ibid.

KMCS, 515 
Rosabel duly finds such a hat and tries it on, at the young woman's request:

"Oh, Harry, isn't it adorable," the girl cried, "I must have that!" She smiled again at Rosabel. "It suits you beautifully."

A sudden, ridiculous feeling of anger had seized Rosabel. She longed to throw the lovely, perishable thing in the girl's face, and bent over the hat, flushing. ${ }^{144}$

The hat allows Rosabel to be seen as beautiful in the eyes of the affluent young couple. Harry, with his partner out of the way, later says:

"Ever been painted?"

"No," said Rosabel shortly, realising the swift change in his voice, the slight tinge of insolence, of familiarity.

"Oh, well you ought to be," said Harry. "You've got such a damned pretty little figure." 145

The implication is sexual, that her "damned pretty little figure" should be painted nude and that she could make herself available to him. Rosabel understands the hat signifies the social divide between herself and the young woman and it makes her angry, which she has to hide. The hat performs as a central mechanism by which Rosabel, the young woman and the young man all interact.

Finally, a reading of a whole story which contains many dramatic devices will illustrate their occurrence as a coherent device in Mansfield's work. "A Married Man's Story" also provides the reader with an example of an overarching use of performativity and stage imagery, as the following analysis demonstrates. It was written in 1921, not finished, and remained unpublished until after Mansfield's death. John Middleton Murry told Ruth Mantz: "No-one could finish "The [sic] Married Man's Story" and live."146 [Original emphasis.] It is an unrelentingly disturbing work, with similarities to the overtly performative "Je ne Parle pas Français." The first person narrators of both stories are posers, liars and cynics and consciously use performance references

\footnotetext{
$144 \quad K M C S, 516$.

145 Ibid.

146 Ruth Elvish Mantz, "Katherine Mansfield: Tormentor and Tormented," ed. Pilditch, Critical Response, 127.
} 
to describe and explain themselves (or not to, as a Wildean, epigrammatic sentence in "A Married Man's Story," reveals: "That is how I long to write... just the plain truth, as only a liar can tell it." 147 This sentence is preceded by: "Why is it so difficult to write simply - and not simply only but sotto voce, if you know what I mean?...no fine effects - no bravura." 148 Sotto voce is a musical term for "under voice," and describes a hushed, tonal quality. "Bravura" is also a musical term, denoting a virtuoso performance and Mansfield can be seen to be expressing her own ambition and literary aesthetic as well as illustrating the profound irony of a narrator who from the opening sentences frames his story in theatrical and performance terms, starting with a stage direction:

It is evening. Supper is over. ${ }^{149}$

We never know the proper name of the narrator of "A Married Man's Story" (1921) who in a series of recollections recounts his life story of chilling loneliness, cruelty and trauma. He begins by describing the current situation of his marriage which, since the previous autumn, has for him become a hollowed-out shell, devoid of warmth and love. He then remembers his sinister chemist father mixing a potion for prostitutes, his mother telling him his father had poisoned her, and his miserable school days. The first paragraph, in setting the scene, employs the least used stage technique in Mansfield's stories, a lighting effect: "and as the fire quickens, falls, flares again, her shadow - an immense Mother and Child - is here and gone upon the wall"150 The effect juxtaposes the significance of the mother-child relationship with that of his wife and their child, whom he suspects: "that when she ties its bonnet she feels like an aunt and not a mother." 151 His own mother's health was so compromised by his birth after nine years of marriage that: "She never left her room again. Bed, sofa, window, she moved between the three."152 Mansfield

KMCS, 428.

Ibid.

KMCS, 422.

KMCS, 423.

KMCS, 425.

KMCS, 430. 
then uses sound effects to create an oceanic sense of memory linked to the sound and experience of water:

While I am here, I am there, lifting my face to the dim sky, and it seems to me it must be raining all over the world - that the whole earth is drenched, is sounding with a soft, quick patter or hard, steady drumming, or gurgling and something that is like laughing and sobbing mingled together, and that light, playful splashing that is of water ${ }^{153}$

The narrator then describes himself in a series of images that read as if they are a cinematic sequence:

And all at one and the same moment I am arriving in a strange city, slipping under the hood of a cab...I am conscious of the tall houses, their doors and shutters sealed...I am brushing through deserted gardens and falling into moist-smelling summer-houses...I am standing on the dark quayside giving my ticket...I am crossing the wet stackyard...And now I am walking along a deserted road ${ }^{154}$

Voice, another sound effect, is also used: "a mournful, glorious voice begins to sing in my bosom... What a voice! What power! What velvety softness! Marvellous!"155

The next section has a stage direction in its first paragraph: "Scene: The supper-table. My wife has just handed me the tea." ${ }^{\text {"156 }}$ Mansfield then uses the clichéd stage techniques of popular theatre:

And immediately there is that famous "blinding flash and deafening roar. Huge pieces of debris (I must say I like debris) are flung into the air ... and when the dark clouds of smoke have drifted away"157

The narrator describes himself as performing for his wife: "I played up...For some reason I feel it would be crude to stop my performance. It's simplest to play on. ${ }^{, 158} \mathrm{He}$ projects this image into the description of the room after his

\footnotetext{
153 KMCS, 423.

$154 K M C S, 423$.

$155 K M C S, 424$.

$156 K M C S, 425$

$157 K M C S, 426$.

158 KMCS, 428.
} 
wife's departure: “...the room changes too. It relaxes, like an old actor. Slowly the mask is rubbed off." ${ }^{159}$ His father is described: "His manner was discreet, sly, faintly amused and tinged with impudence." ${ }^{160}$ We learn that, like an actor, the narrator imitated him: "I even used to copy him in my corner, bending forward, with a small reproduction of his faint sneer." 161 The reference of him sneering is in his childhood, but as a married man, he also sneers at his wife: "Will she never grow accustomed to these simple-one might say-everyday little lies? Will she never learn not to expose herself - or to build up defences?" 162 The narrator is himself utterly defensive, caused by his miserable childhood. After seeing a badly beaten woman come into his father's shop, asking for a "pick-me-up," he recounts his reaction:

long after she had gone I crouched in my corner, and when I think back it's as though I felt my whole body vibrating - "So that's what it is outside," I thought. "That's what it's like out there." $" 163$

Like his father, he poisons his wife, not with chemicals but with the unexplained withdrawal of his love and affection. The above reading displays, in one story, Mansfield using stage directions, a lighting effect, sound effects and references to stage performance and acting. In conclusion, dialogue, sound effects, costume, costume props and stage references in "A Married Man's Story" all contribute to the argument that Mansfield used her experience and understanding of performance in her short stories. She referred to them as "regular performances"164 and wrote of wanting to perform them to large audiences. ${ }^{165}$ There is reference to her speaking them out loud, sounding every word and its effect ${ }^{166}$ in order to achieve the result she desired. The ability to transform several of her dramatic dialogues into stories without requiring much additional writing further illustrates how closely related her stories are to a dramatic form.

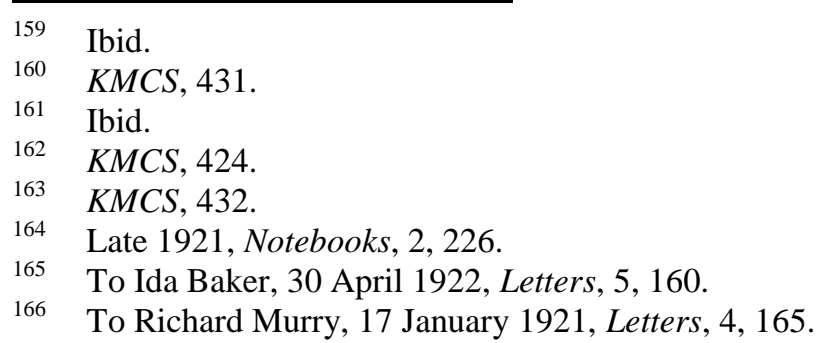




\section{CONCLUSION}

To prove the argument that Mansfield's experience as a performer was a profound influence on her work, this thesis has used three chapters to support and demonstrate the central idea. The first chapter deals with Mansfield's early life and cultural context: the performativity of colonial culture and of her family within that culture, as well as her education and, particularly, musical education. The second chapter examines her later cultural context: her work as a performer and the popular culture of the time. Both chapters emphasise what a cultural sponge Mansfield was both in general and with regard to performance. Panto, dance, film, music hall, classical music, mime - she was deeply attracted to them all. The third chapter sets out to demonstrate how Mansfield deliberately and consistently used explicit, identifiable dramatic techniques in her written work. There is another aspect that works behind the argument which further scholarship could explore. This thesis has concentrated on Mansfield's use of performative devices but there is evidence that the foundation of her method of writing was, itself, performative. There are several pieces of writing which support this idea. An early letter of Mansfield's reads: "Would you not like to try all sorts of lives - one is so very small - but that is the satisfaction of writing - one can impersonate so many

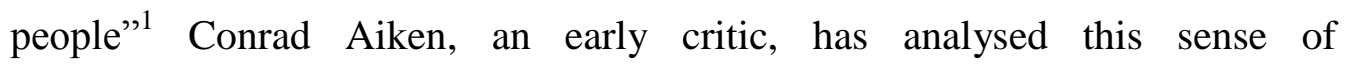
impersonation:

We perceive too clearly that it is all a beautiful, an exquisite, a diabolically clever masquerade, with the protean Miss Mansfield taking now the part of Beryl, now that of "The Young Girl," now that of both "Daughters of the Late Colonel," now that of Miss Brill...Yes these people are all Miss Mansfield, all speak with her voice, think as she thinks ....and represent...so many projections of Miss Mansfield's mind and personality into other people's bodies and houses. How exciting to disguise oneself, for a morning, as Ma Parker, or, for an afternoon, as the singing teacher! ${ }^{2}$

Mansfield herself corroborates this analysis of her process in various references, illustrated by the following letter:

To Sylvia Payne, 24 April 1906, Letters, 1, 19.

Conrad Aiken, "The Short Story as Colour," ed. Pilditch, Critical Response, 9-12. 
I've been this man, been this woman ... I've been out in the stream waiting to be berthed. I've been a seagull hovering at the stern...It is not as if one sits and watches the spectacle. That would be thrilling enough God knows. But one is the spectacle, for the time being. ${ }^{3}$

And in another:

When I write about ducks I swear that I am a white duck with a round eye ... In fact this whole process of becoming the duck $\ldots$ is so thrilling ... There follows the moment when you are more duck, more apple, or more Natasha than any of these objects could possibly be ${ }^{4}$

Elsewhere, Mansfield commented that when she wrote "The Voyage" (1921) she was on the boat, "going down those stairs, smelling the smell of the saloon," and emphasises that it was not a memory of a real experience; it was instead "a kind of possession." 5 What Mansfield describes in the quotations can be termed a form of "method writing" similar to what actors do with "method acting." She thought herself into her characters and her writing technique can be described as a form of ventriloquism, using the performative techniques described in Chapter Three. The following excerpt from a letter explains how she saw her writing as a performative act:

I dreamed a short story last night even down to its name, which was Sun \& Moon. [...] I didn't dream that I read it. No I was in it part of it and it played invisible round me. ${ }^{6}$

This thesis has argued that within Mansfield's work there is a wide-ranging use of performance-based techniques and references, which include specific dramatic techniques as well as motifs and themes that relate to performance. There is the prospect, based on the examples above, that further research could explore Mansfield's performative method of writing as opposed to her use of performative technique.

To John Middleton Murry, 3 November 1920, Letters, 4, 97.

To Dorothy Brett, 11 October 1917, Letters, 1, 330.

To William Gerhardi, 11 March 1922, Letters, 5, 101.

To JMM, 10 and 11 February 1918, Letters, 2, 66. 


\section{BIBLIOGRAPHY}

\section{WORKS BY KATHERINE MANSFIELD}

Dowling, David and Wilhelmina and David Drummond (introduction).

Katherine Mansfield: Dramatic Sketches. Third ed. Palmerston North: Nagare Press, 1989.

Kimber, Gerri and Vincent O'Sullivan (eds). The Edinburgh Edition of the Collected Fiction of Katherine Mansfield, 1898-191. (Volume 1) Edinburgh: Edinburgh University Press, 2012 and The Collected Fiction of Katherine Mansfield 1916-1922 (Volume 2).

Kimber, Gerri and Angela Smith. The Poetry and Critical Writings of Katherine Mansfield. Edinburgh: Edinburgh University Press, 2014.

Mansfield, Katherine. The Collected Stories. 1945. London: Penguin, 2007.

Middleton Murry, Introduction, The Journal of Katherine Mansfield London: Constable, 1927.

O'Sullivan, Vincent and Margaret Scott (eds). The Collected Letters of Katherine Mansfield. Oxford: University Press, Oxford, Volume I, 1903-17, 1984; Volume II, 1918-19, 1987; Volume III, 1919-20; Volume IV, 1920-21; 1996; Volume V, 1921-23, 2008.

Plumridge, Anna (ed.) The Urewera Notebook . Dunedin: Otago University Press, 2015.

Stead, C.K. (ed.) Katherine Mansfield, Letters and Journals. Harmondsworth: Penguin, 1977.

Scott, Margaret (ed). The Notebooks of Katherine Mansfield. Volumes 1 and 2, Lincoln University Press \& Daphne Brasell, Lincoln, 1997.

\section{TEXTS ABOUT KATHERINE MANSFIELD}

\section{Biographies}

Alpers, Antony. The Life of Katherine Mansfield. Oxford: Oxford University Press, 1980.

Baker, Ida. Katherine Mansfield: The Memories of LM. London: Michael Joseph, 1971.

Berkman, Sylvia. Katherine Mansfield: A Critical Study. Connecticut: Yale University Press, 1951.

Boddy, Gillian. Katherine Mansfield: The Woman and the Writer. Auckland: Penguin, 1988.

Brett, Dorothy. "Reminiscences of Katherine." Adam International Review 370-75 (1972-73). 
Rice, Anne Estelle. "Memories of Katherine Mansfield." Adam International Review 300 (1965).

Crone, Nora. A Portrait of Katherine Mansfield. Devon: Arthur H. Stockwell, 1985.

Friis, Anne. Katherine Mansfield Life and Stories. Copenhagen: Einar Munksgaard, 1946.

Jones, Kathleen. Katherine Mansfield the Story-Teller. North Shore: Penguin, 2010.

Kennedy, Julie. Katherine Mansfield in Picton. Auckland: Cape Catley, 2001.

Mantz, Ruth Elvish \& John Middleton Murry. The Life of Katherine Mansfield. London: Constable, 1933.

Meyers, Jeffrey. Katherine Mansfield: A Darker View. New York: Cooper Square, 2002.

Moore, James. Gurdjieff and Mansfield. London: Routledge and Kegan Paul, 1980.

Tomalin, Claire. Katherine Mansfield: A Secret Life. London: Penguin, 1988.

Woods, Joanna. Katerina. Auckland: Penguin, 2001.

\section{Critical Texts}

Ascari, Maurizio. Cinema and the Imagination in Katherine Mansfield's Writing. Hampshire: Palgrave Macmillan, 2014.

Bennett, Andrew. "Hating Katherine Mansfield.” Angelaki, 7:3 (2002): 3-16.

Brophy, Brigid. “Katherine Mansfield's Self-Depiction.” Michigan Quarterly Review, 5 (Spring 1966).

Brophy, Brigid. Don't Never Forget: Collected Views and Review. London: 1967.

Burgan, Mary. Illness, Gender \& Writing The Case of Katherine Mansfield. Maryland: The John Hopkin University Press, 1994.

Chatterjee, Atul Chandra. The Art of Katherine Mansfield: An Enquiry into the Meaning and Technique of the Short Stories of Katherine Mansfield. New Delhi: S. Chand, 1980.

Cork, Richard. "The Cave of the Golden Calf." Artforum, XXI, December 1982.

da Sousa Correa, Delia. "Musical Performance in Katherine Mansfield's Stories." Katherine Mansfield Studies, 3 (2011): 21-34.

da Sousa Correa, Delia. "Musical Performativity in the Fiction of Katherine Mansfield." Word and Music Studies, 12 (2011). 
da Sousa Correa, Delia. "Katherine Mansfield and Nineteenth-Century Musicality." Words and Notes in the Long Nineteenth Century. Eds. Phyllis Weliver, Katherine Ellis. London: Boydell, 2013.

Dunbar, Pamela. Double Discourse in Katherine Mansfield's Short Stories. Hampshire: Macmillan, 1997.

During, Simon. “Katherine Mansfield's World.” Journal of New Zealand Literature. JNZL, 33 (2015): 33-66.

Faulk, Barry J. "Modernism and the Popular: Eliot's Music Halls," Modernism/Modernity, 8 (2001): 603-618.

Ferrall, Charles and Jane Stafford (eds). Katherine Mansfield's Men: Perspectives from the 2004 Katherine Mansfield Birthplace lecture series). Wellington: Katherine Mansfield Birthplace Society in association with Steele Roberts, 2004.

Geheber, Philip Keel. “'Nous ne suivons pas le même route': Flaubertian Objectivity and Mansfield's Representations of Travel." Katherine Mansfield and Translation. Eds. Claire Davison, Gerri Kimber, Todd Martin. Edinburgh: Edinburgh University Press, 2015.

Gunsteren, Julia Van. Katherine Mansfield and Literary Impressionism. Amsterdam: Rodopi BV Editions, 1990.

Hankin, C.A. Katherine Mansfield and her Confessional Stories. London and Basingstoke: Macmillan, 1983.

Hanson, Clare and Andrew Gurr. Katherine Mansfield. London and Basingstoke: Macmillan, 1981.

Harskamp, Jaap. "Underground London: From Cave Follies to the AvantGarde." British Library Journal, 7 (2009): 1-10.

Kaplan, Sydney Janet. Katherine Mansfield and the Origins of Modernist Fiction. New York: Cornell University Press, 1991.

Kaplan, Sydney Janet. Circulating Genius: John Middleton Murry, Katherine Mansfield and D.H. Lawrence. Edinburgh: Edinburgh University Press, 2010.

Kimber, Gerri. Katherine Mansfield: The View from France. Bern: Peter Lang AG, 2008.

Kimber, Gerri and Janet Wilson and Susan Reid. Katherine Mansfield and Literary Modernism. London and New York: Continuum International, 2011.

Kimber, Gerri and Janet Wilson (eds.) Celebrating Katherine Mansfield: A Centenary Volume of Essays. Basingstoke and New York: Palgrave Macmillan, 2011.

Kobler, J.F. Katherine Mansfield A Study of the Short Fiction. Boston: Twayne, 1990. 
McDonnell, Jenny. Katherine Mansfield and the Modernist Marketplace. Hampshire: Palgrave Macmillan, 2010.

Michel, Paulette and Michel Dupuis (eds). Fine Instrument: Essays on Katherine Mansfield: Sydney: Dangaroo, 1989.

Murray, Heather. Double Lives. Dunedin: University of Otago Press, 1990.

Nathan, Rhoda B. (ed). Critical Essays on Katherine Mansfield. New York: Maxwell Macmillan, 1993.

Pilditch, Jan (ed). The Critical Response to Katherine Mansfield. Connecticut: Greenwood Press, 1996.

Pirie, Mark. Katherine Mansfield: A Pioneer Performance Poet. Journal of Commonwealth Literature, 34 (1999): 97 - 100.

Reimer, Melissa C. "Her father's daughter? Katherine Mansfield's Lists." Commonwealth: Essays and Studies. Volume 29.2 (2007): 29 - 43.

Robinson, Roger (ed.) Katherine Mansfield: In from the Margin. Baton Rouge: Louisiana State University Press, 1994.

Smith, Angela. Katherine Mansfield: A Literary Life. London: Palgrave Macmillan, 2000.

Smith, Angela. A Public of Two. Oxford: Clarendon, 1999.

Smith, Angela. Mansfield and Dickens: 'I am not reading Dickens idly.' Bath: Katherine Mansfield Society, 2010.

\section{FICTION}

Colette. The Vagabond. (Trans. Enid McLeod) 1911. Middlesex: Penguin, 1960.

Wilder, Laura Ingalls. Little Town on the Prairie. New York: Harper \& Bros, 1941.

\section{GENERAL}

Aston, Elaine and Geraldine Harris. Feminist futures: theatre, performance, theory. New York: Palgrave Macmillan, 2006.

Baker, Richard Anthony. British Music Hall. Gloucestershire: Sutton, 2005.

Beauchamp, Harold. Reminiscences and Recollections. New Plymouth: T. Avery, 1937.

Brittain, Vera. Radclyffe Hall A Case of Obscenity. London: Femina, 1968.

Debenham, H. \& W. Slinn. Australasian Victorian Studies Association Conference Papers, 1982.

de Marky, Diana. Costume on the Stage 1600 - 1940. New Jersey: Barnes \& Noble, 1982. 
Ellmann, Richard. Oscar Wilde. London: Penguin, 1988.

Fine, Elizabeth C. and Jean Haskell Speer. Performance, Culture and Identity. London, Connecticut: Praeger, 1992.

Gertler, Mark. Selected Letters. ed. Noel Carrington. London: 1965.

Gleeson, Clare. Meet me at Begg's. Wellington: Ngaio, 2012.

Glenavy, Lady. Today We Will Only Gossip. London: Constable, 1964.

Gray, Wilkeson Giles. "The Voice Qualities in the History of Elocution.” The Quarterly Journal of Speech, 29, 4 (2003): 87-103.

Griffiths, Trevor R. Stagecraft. London: Phaidon, 1982.

Harcourt, Peter. Fantasy \& Folly The Lost World of New Zealand Musicals 1880 - 1940. Wellington: Steele Roberts, 2002.

Hassall, Christopher. Edward Marsh: Patron of the Arts. London: Longmans, 1959.

Hoare, Philip. Oscar Wilde's Last Stand. New York: Arcade, 1997.

Hollington, Michael. (ed.) Introduction. The Reception of Charles Dickens in Europe. London: Bloomsbury, 2013.

Irvine-Smith. The Streets of My City. Wellington: 1949.

Laitz, Steven G. The Complete Musician. New York: Oxford University Press, 2008.

Laver, James. Costume in the Theatre. London, Toronto: George G. Harrap, 1964.

Lawlor, Pat. Old Wellington Days. Wellington: Whitcombe \& Tombs, 1959.

Lea, F.A. The Life of John Middleton Murry. London: Methuen, 1959.

McCann, Andrew. "Romantic Self-Fashioning: John Thelwall and the Science of Elocution." Studies in Romanticism, 40, 2 (2001): 215-232.

MacGibbon, John. Piano in the Parlour. Wellington: Ngaio, 2007.

McLeod, Beth Abelson. Women Performing Music: The Emergence of American Women and Instrumentalists and Conductors. Chicago: University of Illinois Press, 2004.

Moffatt, Kirstine. Piano Forte Stories and Soundscapes from Colonial New Zealand. Dunedin: Otago University Press, 2011.

Murray, Tosti. The History of a New Zealand School for Girls. Christchurch: Caxton, 1967.

Murry, John Middleton. Between Two Worlds. London: Jonathan Cape, 1935. 
Norburn, Roger. A Katherine Mansfield Chronology. Hampshire: Palgrave Macmillan, 2008.

Rayfield, Donald. Anton Chekhov: A Life. New York: Henry Holt, 2013.

Schechner, Richard. Performance Theory. London: Routledge, 1988.

Scott, Linda M. Fresh Lipstick. New York and Hampshire: Palgrave Macmillan, 2005.

Simon, J. "Historical Perspectives in Schooling." The Politics of Learning in Aotearoa New Zealand. Eds. E. Coxon, K. Jenkins and J. Marshall, L. Massey. Palmerston North: Dunmore, 1994.

Thurman, Judith. Secrets of the Flesh A Life of Colette. London: Bloomsbury, 1999.

Thomson, John. The New Zealand Stage 1891 - 1900. Wellington: Victoria University Press, 1993.

Tomalin, Claire. The Invisible Woman. London: Penguin, 1991.

Wood, June A. Victorian New Zealanders. Wellington: A.H. \& A.W. Reed, 1974.

Woods, Joanna. Facing the Music: Charles Baeyertz and the Triad. Dunedin: Otago University Press, 2008.

Riley, Charles A. Aristocracy and the Modern Imagination. Hanover: University Press of New England, 2001.

Walker, Kenneth. Gurdjieff A Study of His Teaching. London: Mandala, 1979.

Weber, Eugen. France Fin de Siècle. Cambridge, Mass: The Belknap Press of Harvard University, 1986.

Woolf, Leonard and James Strachey (eds.) Virginia Woolf and Lytton Strachey: Letters, Hogarth, 1956.

Woolf, Leonard. Beginning Again: An Autobiography of the Years 1911 1918. London: Hogarth, 1964.

Woolf, Virginia. The Letters of Virginia Woolf. London: Hogarth, 1976.

Woolf, Virginia. The Diary of Virginia Woolf. ed. Anne Olivier Bell. London: Hogarth, 1978. 